\title{
Branched chain amino acid enrichment of total parenteral nutrition solutions : a prospective randomized double blind study in septic and traumatized patients
}

Citation for published version (APA):

Vente, J. P. (1991). Branched chain amino acid enrichment of total parenteral nutrition solutions : a prospective randomized double blind study in septic and traumatized patients. [Doctoral Thesis, Maastricht University]. Maastricht University. https://doi.org/10.26481/dis.19910621jv

Document status and date:

Published: 01/01/1991

DOI:

10.26481/dis.19910621jv

Document Version:

Publisher's PDF, also known as Version of record

Please check the document version of this publication:

- A submitted manuscript is the version of the article upon submission and before peer-review. There can be important differences between the submitted version and the official published version of record. People interested in the research are advised to contact the author for the final version of the publication, or visit the DOI to the publisher's website.

- The final author version and the galley proof are versions of the publication after peer review.

- The final published version features the final layout of the paper including the volume, issue and page numbers.

Link to publication

\footnotetext{
General rights rights.

- You may freely distribute the URL identifying the publication in the public portal. please follow below link for the End User Agreement:

www.umlib.nl/taverne-license

Take down policy

If you believe that this document breaches copyright please contact us at:

repository@maastrichtuniversity.nl

providing details and we will investigate your claim.
}

Copyright and moral rights for the publications made accessible in the public portal are retained by the authors and/or other copyright owners and it is a condition of accessing publications that users recognise and abide by the legal requirements associated with these

- Users may download and print one copy of any publication from the public portal for the purpose of private study or research.

- You may not further distribute the material or use it for any profit-making activity or commercial gain

If the publication is distributed under the terms of Article 25fa of the Dutch Copyright Act, indicated by the "Taverne" license above, 


\section{Branched chain amino acid enrichment of total parenteral nutrition solutions}

A prospective randomized double blind study in septic and traumatized patients 


\section{Branched chain amino acid enrichment of total parenteral nutrition solutions}

A prospective randomized double blind study in septic and traumatized patients

\section{PROEFSCHRIFT}

ter verkrijging van de graad van doctor aan de Rijksuniversiteit Limburg te Maastricht, op gezag van de Rector Magnificus, Prof. Mr. M.J. Cohen, volgens het besluit van het College van Dekanen, in het openbaar te verdedigen op vrijdag, 21 juni 1991 om 14.00 uur

$$
\text { door }
$$

Johannes Pieter Vente

geboren 10 februari 1950 te Zwolle 


\title{
Promotor
}

Prof. Dr. P.B. Soeters

\section{Co-promotor}

Dr. M.F, von Meyenfeldt

\section{Beoordelingscommissie}

\author{
Prof. Dr. W.H.M. Saris (voorzitter) \\ Prof. Dr. S. de Lange \\ Dr. H.P. Sauerwein, Acad. Medisch Centrum Amsterdam \\ Prof. Dr. A. Sitges-Serra, Universidad Autónoma de Barcelona \\ Prof. Dr. R.W. Stockbrügger \\ Prof. Dr. R.I.C. Wesdorp, VU Amsterdam
}

Vente, Johannes Pieter

Branched chain amino acid enrichment of total parenteral nutrition solutions : a prospective randomized double blind study in septic and traumatized patients / Johannes Pieter Vente - Maastricht : Datawyse. - IIl.

Thesis Maastricht. - With ref. - With summary in Dutch. ISBN 90-5291-052-9

NUGI 742

Subject headings: branched chain amino acid / sepsis / total parenteral nutrition (TPN)

Produktie en lay-out: Datawyse Maastricht, Ruud Leliveld Druk: Krips Repro Meppel

This study was supported by Baxter-Travenol.

The thesis was financially supported by Kabi Pharmacia B.V. 
Aan Aky, Liesbeth en Marieke 


\section{Parts of this thesis have been published in the following papers}

P.B. Soeters, J.P. Vente. Use of BCAA enriched nutritional regimens in hepatic failure and sepsis: facts or fancy. In: Bengmark (ed): Progress in Surgery of the Liver, Pancreas and Biliary System. Martinus Nijhoff Publishers, Dordrecht etc., p. 349-361, 1988.

P.B. Soeters, J.P. Vente, M.F. von Meyenfeldt. BCAA enriched formulas in special settings. In Sitges-Serra, Sitges-Creus, Schwartz-Riera (eds.): Clinical Progress in Nutrition Research. Karger, Basel, p. 21-32, 1988.

M.F. von Meyenfeldt, J.P. Vente, P.B. Soeters. Use of BCAA enriched formulas in liver disease and trauma. Riv. Ital. di Nutr. Par. Ent. 6: 97-104, 1988.

J.P. Vente, M.F. von Meyenfeldt, C.L.H. van Berlo, H. van Eyk, D.J. Gouma, C.J. wan der Linden, P.B. Soeters. Plasma amino acid profiles in sepsis and stress. Ann. Surg. 209: 57-62, 1989.

M.F. von Meyenfeldt, C.L.H. van Berlo, J.P. Vente, M. Roufflart, K.P. de Jong, C.J. van der Linden, D.J. Gouma, P.B. Soeters. Effect of branched-chain amino acid enrichment of total parenteral nutrition on nitrogen sparing and clinical outcome of sepsis and trauma: a prospective randomized double blind trial. $\mathrm{Br} \mathrm{J}$ Surgery 77: 924-929, 1990.

J.P. Vente, M.F. von Meyenfeldt, H.M.H. van Eijk, C.L.H. van Berlo, D.J. Gouma, C.J. v.d. Linden, P.B. Soeters. Effects of infusion of branched-chain amino acids enriched TPN solutions on plasma amino acid profiles in sepsis and trauma. Clinical Nutrition 9: 241-245, 1990.

J.P. Vente, P.B. Soeters, M.F. von Meyenfeldt, M. Roufflart, C.J. van der Linden, D.J. Gouma. Prospective randomized double blind trial of branched-chain amino acid enrichment versus standard parenteral solutions in traumatized and septic patients. World J of Surgery 15:128-133, 1991

J.P. Vente, M.F. von Meyenfeldt, C.J. van der Linden, D.J. Gouma, P.B. Soeters. Morbidity and mortality in sepsis and stress: The Elebute and Stoner sepsis gradation related to morbidity parameters. Submitted for publication, 1991. 


\section{Contents}

\section{CHAPTER 1}

Introduction 9

- Intermediary metabolism 9

- Branched-chain Amino Acids 12

- Introduction 12

- Metabolism of the branched-chain amino acids 12

- in vivo studies with BCAA containing solutions 16

- Administration of BCAA-enriched solutions in clinical settings 19

- References 27

\section{CHAPTER 2}

Present study, patients and methods 31

- Aim of the study 31

- Patients and methods 32

- References 40

\section{CHAPTER 3}

Branched chain amino acid enrichment of total parenteral nutrition (TPN) fails to induce nitrogen sparing and alter clinical outcome of sepsis and trauma 41

- Summary 41

- Introduction 42

- Patients and methods 43

- Results 45

- Discussion 49

- References 56

CHAPTER 4

A prospective randomized double blind trial of branched-chain amino acid enriched versus standard parenteral solutions in traumatized and septic patients $\quad 59$

- Summary 59

- Introduction 60

- Patients and methods 60

- Results 62

- Discussion 67

- References 70 
CHAPTER 5

Plasma amino acid profiles in sepsis and stress $\quad 73$

- Summary 73

- Introduction 73

- Patients and methods 74

- Results 77

- Discussion 83

- References 86

CHAPTER 6

Effects of infusion of branched chain amino acids enriched TPN solutions on plasma amino acid profiles in sepsis and trauma 89

- Summary 89

- Introduction 89

- Patients and methods 90

- Results 92

- Discussion 97

- References 99

CHAPTER 7

Morbidity and mortality in sepsis and stress: the Elebute and Stoner sepsis gradation related to morbidity parameters 101

- Summary 101

- Introduction 102

- Patients and methods 103

- Results 104

- Discussion 106

- References 108

CHAPTER 8

General conclusion $\quad 109$

Summary $\quad 111$

Samenvatting 115

Acknowledgements $\quad 119$

Curriculum Vitae $\quad 121$ 


\section{Chapter 1}

\section{Introduction}

\section{INTERMEDIARY METABOLISM}

Intermediary metabolism in starvation associated with sepsis and trauma differs considerably from starvation without concomitant disease. During starvation endogenous fat is mobilized which can meet the energy demands of most tissues. Even the brain which utilises glucose in the postabsorptive state switches to the utilization of ketone-bodies derived from the partial degradation of fatty acids in the liver (Owen 1967). Most other tissues including skeletal and cardiac muscle use fatty acids to meet their energy demands. Only a few tissues (erythrocytes, bone marrow, renal medulla, peripheral nerve) continue to use small amounts of glucose. In this way the organism limits its requirements for the new formation of glucose. As new formation of glucose requires carbon skeletons from amino acids or glycerol this simultaneously diminishes the need to degrade (muscle) protein (Cahill 1970). Lactate and pyruvate as a precursor for gluconeogenesis in the liver do not furnish new glucose because they are derived from glycolysis (Cori-cycle). It has been repeatedly shown that a healthy $70 \mathrm{~kg}$ individual can limit his/her urinary nitrogen losses to $5 \mathrm{~g} \mathrm{~N} / 70 \mathrm{~kg} / 24 \mathrm{~h}$ (Benedict 1915, Felig 1970).

In sepsis and trauma the mobilisation of endogenous fat which is characteristic for starvation continues despite high glucose and insulin levels (Ryan 1974, Gump 1974, Clowes 1978, Wichterman 1979), which would normally suppress lipolysis and fatty acid and ketone-body utilization. Also administration of exogenous glucose and insulin do not inhibit lipolysis completely (Askanazi 1980, Nordenström 1983).

In contrast to the adaptation to starvation leading to protein sparing and increased use of FFA as energy source, proteolysis is increased in trauma and sepsis which implies that the release of amino acids from muscle in these conditions is enhanced (Clowes 1980). In septic conditions the release of alanine and glutamine from muscle is three to four times more than can be accounted for by their concentration in muscle, and plasma levels of alanine are significantly 
increased compared to normal fasting conditions (Imamura 1975, Clowes 1976 , Cerra 1979). De-novo synthesis of alanine and glutamine has been demonstrated to occur in muscle from amino acids such as the BCAA, cystine, methionine, serine, threonine, glycine and lysine (Odessey 1974, Garber 1976). The most important gluconeogenic precursor in the liver is alanine (Felig 1970). Wilmore (1980) demonstrated a three to four times increased hepatic uptake of alanine in septic conditions compared to the postabsorptive state while hepatic glucose output more than doubled. Glutamine is the most abundant amino acid in the body. Glutamine depletion is a characteristic feature of critical illness and results in part from accelerated release of glutamine by skeletal muscle, and from argumented uptake of glutamine by the gastrointestinal tract, where this amino acid is the principal fuel. In the mucosal cell glutamine is hydrolyzed to glutaminic acid and $\mathrm{NH}_{3}$, both being released in the portal circulation (Windmueller 1982, Souba 1985).

Increased hepatic gluconeogenesis in sepsis and trauma may serve to furnish glucose for tissues that exclusively rely on glucose to meet their energy requirements such as reparative tissues, anoxic tissues and tissues that are always glucose-dependent (Kinney 1970). Gump (1974) demonstrated that the glucose production required to meet energy requirements of specific tissues could not be significantly inhibited by administration of exogenous glucose. The main precursors of hepatic gluconeogenesis and especially the precursors of new glucose are the carbon skeletons of amino acids. Therefore, ongoing formation of new glucose in a septic and starved individual is related to ongoing proteolysis and nitrogen losses which amount to $15-30 \mathrm{~g}$ Nitrogen $/ 70 \mathrm{~kg} / 24 \mathrm{~h}$. Parallel to the observation (see above) that gluconeogenesis cannot be inhibited by administration of exogenous glucose, these nitrogen losses cannot or can only slightly be inhibited by conventional nutritional regimens (Shenkin 1980). Much speculation exists concerning this seemingly obligatory net proteolysis (auto-cannibalism). The requirement for glucose in special reparative and damaged tissues has already been mentioned.

It has also been hypothesized that in the septic/traumatic state a muscle energy deficit might arise resulting from glucose intolerance and a degree of lipolysis which was still not sufficient to meet energy requirements. Proteolysis would then furnish amino acids of which specifically the BCAA can directly be oxidized in muscle. It has indeed been demonstrated that oxidation of BCAA in muscle in sepsis is enhanced but it can be calculated that it provides only $5 \%$ of the energy requirement if they are indeed degraded as the sole alternative energy fuel (Soeters 1985). Clowes (1984) has demonstrated that traumatized liver patients only survive when substantial amounts of amino acids released by peripheral tissues are taken up by the splanchnic region (presumably the liver) and he 
suggests that the, probably cytokine mediated, catabolic response serves to furnish the splanchnic tissues (liver, gut and spleen) with substrate necessary to generate a host response essential in the defense against trauma/sepsis. This increased proteolysis is necessary to produce acute phase proteins, opsonins, complement factors, white cells and proteins required for repair processes. One amino acid generated in peripheral tissues and used in the gut and immune cells is glutamine which received much attention recently and is considered by some as a semi-essential amino acid (Souba 1990).

It is difficult to understand why, if the provision of glucose and amino acids is a primary purpose of the metabolic response, such a response can not be attenuated by supplying these substances exogenously. Nor is it easy to understand why, if the provision of energy (BCAA) or reutilization of amino acids is a primary goal of the metabolic response, this response is so terribly inefficient: very little extra energy is derived, only a small proportion of amino acids derived from proteolysis is effectively reutilized while a large proportion is irreversibly degraded leading to enhanced nitrogen losses.

It is possible that these hypotheses are not mutually exclusive but that they integrate. The fact for instance, that reutilization of amino acids derived from peripheral proteolysis is very inefficient because onlly a small portion is actually reutilized to furnish proteins, cells etc. operative in host defense and a large proportion is irreversibly degraded leading to a net negative nitrogen balance, may be explained by the fact that simultaneously new glucose is required. That still does not explain why these net protein losses cannot be overcome by supplying glucose and amino acids.

Potential reasons are again severalfold:

1. It is possible that the neuroendocrine signals evoked by sepsis and trauma program the tissues and the liver to become catabolic resp. to produce urea and glucose, whereas this programming cannot be overcome by supplying the appropriate substrates.

2. It is also possible that conventional nutritional support systems are inadequate to meet substrate requirements.

In this study we will study the effects of modifying the conventional amino acid composition of artificial nutrition administered to severely ill patients by supplementation with BCAA.

The rationale for BCAA enrichment relies on several considerations:

1. Hypothetically BCAA may serve to cover an energy deficit in muscle.

2. Experimental in vitro and in vivo data suggest that $B C A A$ have special anabolic properties. 
3. Septic/traumatized patients exhibit disproportional low plasma BCAA levels which among other explanations could be explained by a shortage of BCAA.

4. Clinical studies have suggested but not proved that BCAA enrichment may be of benefit.

In the remaining part of this chapter these considerations will be discussed in more detail. In chapter 3-7 the effects of BCAA enrichment on metabolic parameters and clinical outcome will be assessed in a prospective randomized clinical study.

\section{BRANCHED CHAIN AMINO ACIDS}

\section{Introduction}

Branched-chain amino acids absorbed from the gut after a meal pass the liver intact for $80 \%$ and reach the systemic circulation. The remaining $20 \%$ is used for hepatic protein synthesis. Very little is degraded in the liver as the concentration of BCAA transaminase in liver is very low. After reaching the systemic circulation the BCAA are taken up by peripheral tissues and used for protein synthesis or they are transaminated and degraded. Degradation takes largely place in muscle, kidney, adipose tissue and brain. Metabolism of the other essential amino acids and all non-essential amino acids is regulated by the liver (Munro 1984, Harper 1984).

Metabolism of the branched-chain amino acids

The branched-chain amino acids valine, leucine and isoleucine are essential amino acids. Dietary protein and endogenous proteolysis are the only sources to provide these amino acids for protein synthesis.

Isoleucine Leucine Valine<smiles>CCC(C)C(N)C(=O)O</smiles>

Degradation of the BCAA is possible via several pathways. 


\section{Reversible transamination}

The branched-chain amino acids undergo a reversible transamination with the transfer of the amino-group to a-keto-glutarate to form glutamate. For this step branched-chain amino-transferase is needed (see figure 1).

\section{Figure 1}

Glutamine
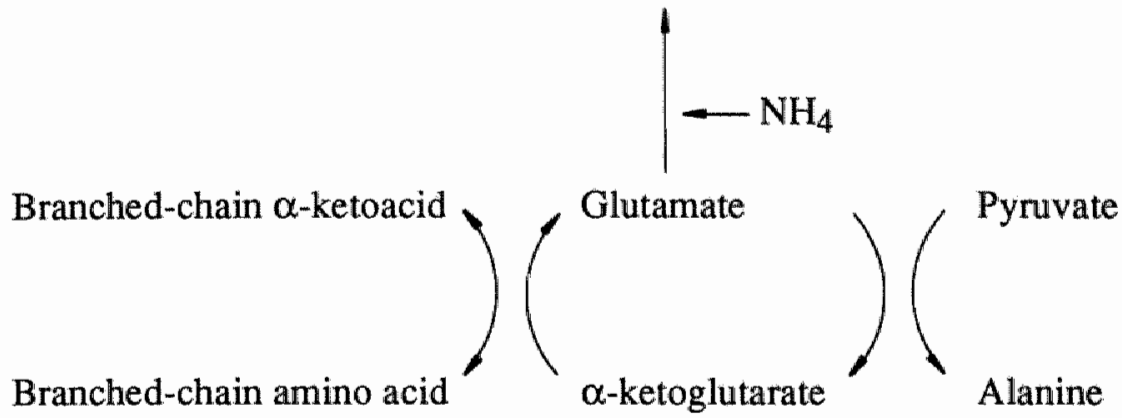

Glutamate has different pathways. Increased hepatic gluconeogenesis and degradation of the amino acids cystine, methionine, serine and glycine lead to increased pyruvate levels, that stimulate the transformation of glutamate to alanine. Deamination of the amino acids serine, glycine, threonine, phenylalanine and tyrosine lead to an increased production of $\mathrm{NH}_{4}$ which stimulates the production of glutamine (Odessey 1974, Garber 1976).

Alanine is an, if not the most, important precursor for hepatic gluconeogenesis, while glutamine is an important fuel source for the gut and cells of the immune system. After degradation of glutamine the amide nitrogen is largely released as $\mathrm{NH}_{3}$ and the amino nitrogen as alanine into the portal vein. In the kidney degradation of glutamine also yields $\mathrm{NH}_{3}$ which serves to buffer $\mathrm{H}^{+}$ions in the urine. (Munro 1984, Harper 1984).

Transamination is the first step in the degradation of the branched-chain amino acids. Three iso-enzymes of branched-chain amino acid-transaminase, which are responsible for removal of the amino-group, have been described in tissues (Ichihara 1973). Among liver, muscle and kidney, muscle tissue contains the highest total amount of transaminase. However, the specific activity is highest in the kidney and lowest in the liver (Adibi 1976). 


\section{Irreversible decarboxylation}

Transamination of valine, leucine and isoleucine results in the formation of $\alpha$-ketoisocaproic acid, $\alpha$-keto- $\beta$-methylvaleric acid and $\alpha$-ketoisovaleric acid. Dehydrogenation of these keto-acids results in the loss of the carboxyl $(\mathrm{COOH})$ group and the formation of thio-esters of $\mathrm{Co}$-enzyme $\mathrm{A}$. These oxidative decarboxylation activities of the branched-chain keto-acids are located principally in the mitochondria. The three branched-chain acetyl $\mathrm{Co}-\mathrm{A}$ products are further oxidized through a series of reactions to either acetyl (leucine) or to acetyl and propionate fragments (isoleucine and valine), which can finally be oxidized to $\mathrm{CO}_{2}$ and $\mathrm{H}_{2} \mathrm{O}$ in the Krebs cycle (Adibi 1976).

Muscle is the major site of degradation of the branched-chain amino acids, while hardly any degradation occurs in the liver. Although activity of branchedchain ketoacid-dehydrogenase, which is responsible for the irreversible decarboxylation of the branched-chain-ketoacids is substantial in the liver, the small capacity for transamination of the branched-chain amino acids appears to be the rate limiting factor in the oxidation of these amino acids in the liver (Adibi 1976, Walser 1984). As the activity of BCKA dehydrogenase is also high in adipose tissue a substantial proportion of the BCAA can be degraded in adipose tissue when the BCAA are administered in excess.

\section{Lipid conversion}

Incomplete oxidation of the BCAA produces $\beta$-hydroxy- $\beta$-glutaryl CoA, which is a direct precursor of cholesterol. Lipid conversion is most efficiently achieved with leucine and quantitatively most important in extra-hepatic tissues. The final products of leucine oxidation are aceto-acetate and acetyl-CoA. Isoleucine oxidation produces acetyl-CoA.

These products may serve as starting material for the synthesis of fatty acids and lipid synthesis (Adibi 1976, Adibi 1980)

\section{Stimulation of protein synthesis and inhibition of proteolysis}

In experiments with rat diaphragm Odessey (1974) found that the branched-chain amino acids leucine, isoleucine and valine inhibited net protein breakdown in muscle. The release of tyrosine and phenylalanine decreased in a concentrationdependent manner by addition of the BCAA in the medium.

Fulks observed in isolated rat diaphragm that addition of the BCAA to the medium promoted protein synthesis and inhibited degradation. Leucine by itself and isoleucine and valine together, were also able to inhibit protein degradation and promote protein synthesis (Fulks 1975). 
Buse and Reid (1975) studlied incorporation of radiolabeled precursors into muscle protein in isolated rat diaphragm. They reported that a mixture of the three branched-chain amino acids added to a medium containing glucose stimulated the incorporation of $\mathrm{C}^{14}$-lysine into protein. When tested separately, valine was ineffective, isoleucine was inhibitory, but $0.5 \mathrm{mM}$ of leucine increased the specific activity of muscle protein during incubation with $\mathrm{C}^{14}$-lysine or $\mathrm{C}^{14}$. acetate in diaphragm. They demonstrated that leucine both inhibits protein degradation and promotes protein synthesis.

Chua (1979) found that leucine, but not isoleucine and valine, inhibited protein degradation and accelerated protein synthesis in hearts perfused with a buffer containing glucose and normall plasma levels of other amino acids, except for the branched-chain compounds. Increased protein synthesis was also found after addition of $\alpha$-keto-isocaproate and the metabolites of the BCAA: proprionate, acetoacetate and acetate. Furthermore, he observed in experiments with working rat hearts an inhibitory effect of leucine on protein degradation. A stimulatory effect of leucine on protein synthesis was not found in this working- heart preparation (Chua 1980).

Morgan (1984), however, reported that leucine was an important regulator of protein tum over in heart muscle, because it accelerated protein synthesis and inhibited protein degradation.

Tischler (1982) found that the addition of cycloserine prevented the inhibition of proteolysis by leucine, suggesting that transamination of leucine into $\alpha$-ketoisocaproate (KIC) was required for this inhibitory effect. This nitrogen-sparing effect of reduced protein degradation by $\mathrm{KIC}$, and not leucine, was confirmed in postoperative patients by Sapir et al (1984).

Thus, the studies in cardiac and skeletal muscle ascribe a regulatory function to the BCAA in protein turnover. In addition to this, there is also evidence that the branched-chain amino acids improve systolic function in hearts from both normal and septic rats.

Freund (1985) studied the effects of amino acid solutions differing in their branched-chain amino acid concentrations, on the systolic capacity and coronary flow in Langendorf preparations of normal and septic rat hearts. During perfusion with a solution enriched with $42 \%$ BCAA the systolic properties in septic rat hearts improved considerably compared with solutions containing $15 \%$ and $100 \%$ BCAA accompanied by a significant rise in coronary flow, presumably in response to the improved contractility.

Markovitz (1985) also studied the effects of the branched-chain amino acids on the systolic function of isolated normal and septic rat hearts. In normal hearts the developed force and force velocity decreased significantly during perfusion with 
leucine and isoleucine. In sepsis, perfusion with leucine and isoleucine resulted in a mild improvement in systolic function. However, valine was far less effective than leucine and isoleucine in maintaining systolic function in sepsis.

Kikuchi (1987) reported increased protein synthesis in liver and skeletal muscle, measured by RNA/DNA ratios and ribosome profiles, after infusion of BCAA-enriched solutions. He also found muscle protein degradation to be reduced.

Hasselgren (1988) found no differences in protein tum-over in skeletal muscle in rat after infusion of KIA alone or administered with a BCAA-enriched amino acid solution.

In another study the same group (1988) reported that leucine stimulates protein synthesis and reduces protein breakdown in normal muscle. KIA only reduces muscle proteolysis. In septic conditions protein synthesis was also stimulated by leucine, but only in concentrations higher than that needed to affect protein synthesis in normal muscle. However, protein degradation in sepsis was not affected by leucine and KIA.

Finally Pederson (1988) found that synthesis of proteins in perfused livers was not increased after infusion of amino acid solutions with different BCAA contents compared to a dextrose solution.

From these in vitro experiments one may conclude that the branched-chain amino acids have anti-catabolic properties, although not every experiment supported this conclusion in every aspect. In cardiac and skeletal muscle protein synthesis is promoted and protein degradation is inhibited. Hepatic protein synthesis seems to be promoted. Not only the BCAA, but also the keto-acids of the BCAA and metabolites have these properties. In these in vitro experiments it seems as if leucine has a major regulatory function.

\section{In vivo studies with BCAA containing solutions}

From 1978 on in vivo studies appear investigating the characteristics of BCAA concerning protein metabolism, that were previously found in in vitro studies.

Freund $(1978,1980,1981)$ performed a series of studies in Sprague-Dawley rats to investigate the influence of amino acid solutions with various amounts of BCAA on postinjury metabolism.

He found the administration of solutions with different BCAA contents to result in an improved nitrogen balance compared to control groups receiving dextrose $5 \%$. It is, however, confusing that the use of solutions with $35 \%$ and $100 \% \mathrm{BCAA}$ resulted in a better nitrogen balance than the use of solutions with $22 \%$ and $52 \%$ BCAA dose in one study (Freund 1978), but that in another study (Freund 1980) nitrogen balances are not different between these groups. 
The plasma amino acid concentrations of almost all amino acids were increased in the various BCAA-containing solutions. However, a near normal amino acid pattern in plasma was found when a $100 \%$ BCAA solution was administered with the exception of alanine, valine, leucine and isoleucine concentrations that showed significant elevations (Freund 1980).

Freund suggests a complete shut-off of amino acid efflux from muscle leading to the near normal plasma amino acid pattern. However, his data could also indicate that the amino acid profile in plasma is an exact copy of the infusate. Comparing a $3 \%$ solution of alanine with a $3 \%$ solution with one of the three $\mathrm{BCAA}$ revealed that the BCAA have the same nitrogen sparing effect as alanine (Freund 1980). Freund's findings are confusing. He suggests that BCAA-enriched solutions induce a more positive nitrogen balance than the standard solutions, but without clear evidence: his conclusions are based on plasma amino acid profiles which resemble the normal amino acid pattern when increased amounts of BCAA are given and on one study that reported a better nitrogen balance when the standard solution was compared with two of three enriched solutions. Adding ${ }^{11}$-C-tyrosine to the infusate to determine total body protein degradation and fractional synthesis rate in liver and muscle, he found all three BCAA to increase fractional synthesis of liver protein, but the synthesis rate in muscle was only increased in the group receiving valine (Freund 1981).

Using the same method, Blackburn (1979) also found increased protein synthesis rates in liver and muscle and improved nitrogen balance in a septic fracture rat model after administration of BCAA containing solutions if compared to solutions containing no nutrition. The $50 \%$ BCAA solution that preserved total liver nitrogen best, was associated with the highest fractional protein synthetic rate.

Gimmon (1985), testing amino acid solutions with a BCAA content varying from $22 \%$ to $50 \%$, found that the $45 \%$ BCAA-containing solution induced the highest nitrogen sparing effect, induced minor distortions of plasma amino acid patterns and significantly higher plasma albumin levels.

Nachbauer (1984) found that septic guinea pigs receiving a $45 \%$ leucineweighted BCAA containing solution excreted significantly less 3-methylhistidine indicating reduced muscle degradation than a valine-weighted $45 \%$ BCAA and a standard (25\% BCAA) solution. Plasma valine and isoleucine were excessively increased, while leucine levels were increased in the same range as the other amino acids suggesting a superior up-take and utilization of leucine.

Lindberg (1981) found that sepsis induced an increased hepatic up-take of amino acids. This amino acid up-take increased further during hyperalimentation, suggesting increased hepatic protein synthesis. When leucine was administered only a small arterio-venous difference of the sum of all amino acids was measured over an extremity indicating a complete cessation of muscle proteolysis. 
Hasselgren (1988) found in septic rats a positive nitrogen balance despite increased nitrogen excretion in groups receiving BCAA enriched solutions, but there was no difference between the groups receiving 45\% BCAA and the group receiving $45 \% \mathrm{BCAA}$ and a-ketoisocaproic acid (KIA), the deamination product of leucine.

Kikuchi (1987) found in the in vivo part of his septic rat study that under conditions of marginal or deficient energy supply, the beneficial effets of BCAAenrichment of a parenteral nutritional regimen became more apparent. Body weight loss and muscle protein degradation, judged by 3-MH excretion, decreased. Studying the rate of muscle prostaglandin production, which is reported to mediate muscle protein breakdown via activation of lysosomal proteases, Freund (1985) found no differences between normal and septic rats. A limentation with different amounts of BCAA did not have any significant effect on PG-production.

Mori (1988) found that rats receiving a solution containing $35.8 \%$ BCAA survived sepsis better than rats receiving a standard amino acid solution. The BCAA-enriched solution also displayed a significantly better nitrogen balance.

Pedersen (1988) demonstrated this nitrogen sparing effect in both a balanced and a BCAA-enriched TPN solution. With the flooding dose technique he demonstrated that total hepatic protein synthesis was not higher in rats receiving the amino acid solutions than in rats treated with dextrose alone.

\section{CONCLUSIONS}

Administration of amino acid solutions in septic rat models has a nitrogen sparing effect. Most authors found that increasing amounts of BCAA result in a further improvement of nitrogen balance. Several studies reported increased fractional synthesis of proteins in liver and muscle indicating increased production of acute-phase proteins as well as structural long tum-over proteins. A few studies reported decreased 3-methylhistidine excretion or small arterio-venous differences of amino acids indicating a decreased proteolysis. Enrichment of the amino acid solution with $45 \%$ BCAA seems to be most favourable. Increased production of alanine which serves as substrate for the glucose-alanine cycle and so contributes to the decreased muscle breakdown, explains only part of the nitrogensparing qualities of the BCAA.

Leucine is of special interest because it seems to inhibit protein degradation. 


\section{Administration of BCAA-enriched solutions in clinical settings}

Since 1979 the use of BCAA- enriched solutions in clinical settings is reported in patients with sepsis and/or trauma and postoperative stress. In most studies only a small number of patients is involved. Exceptions are the studies by Cerra, a multi-center trial including 87 patients (Cerra 1987), and by Okada (1988) who studied 173 patients with gastric cancer postoperatively after total or subtotal gastrectomy, also in a multicenter design.

\section{Prospective trials}

Kern (1982) studied 10 patients with postoperative moderate stress receiving parenteral nutrition with a $45 \%$ BCAA amino acid solution during 5 days. No major postoperative complications or wound infections occurred and the patients were in nitrogen equilibrium for all 5 postoperative days.

Eschenique (1984) found a significantly increased plasma leucine flux, oxidation and balance in 5 critically ill patients when a 50\% BCAA-enriched aminoacid solution was given compared to a standard solution.

Plasma leucine, isoleucine and valine concentrations were significantly increased with the administration of the BCAA-enriched solution, while plasma levels of tyrosine and phenylalanine were significantly reduced, suggesting reduced muscle proteolysis.

Bonau (1984) studied the nitrogen-sparing effect of three amino acid solutions in 25 patients after radical cystectomy. The groups that received amino acids and dextrose had a significantly better cumulative nitrogen balance than the control group receiving $5 \%$ dextrose. The group receiving the $45 \%$ BCAA (low leucine/high valine) solution had a significantly lower mean cumulative nitrogen balance than the groups receiving the $25 \%$ and $45 \%$ (high leucine) solutions.

Protein kinetic studies showed that whole body protein flux was increased in all groups receiving aminoacids. Patients receiving the $45 \%$ (low leucine/high valine) solution demonstrated a higher rate of whole body catabolism than the other groups. There appears to be a critical level of leucine required to significantly improve nitrogen balance. For patients undergoing major elective operations that level appears to be $0.13 \mathrm{~g} / \mathrm{kg} /$ day of leucine.

Bower (1985) found a positive mean daily nitrogen balance in 20 postoperative patients with moderate metabolic stress when parenteral nutrition with a $45 \%$ BCAA enriched amino acid solution was infused during 7 to 14 days. 3-methylhistidine excretion decreased and serum transferrin increased during the infusion period without reaching statistical significance. Albumin levels showed no significant changes. Plasma amino acid profiles showed a two- to threefold increase of valine and isoleucine, corresponding to the increased concentrations of these amino acids in the infusate, but leucine was maintained at normal levels. 


\section{Prospective randomized trials}

Since 1979 prospective randomized trials investigating the effects of amino acid solutions enriched with branched-chain amino acids have been performed (table 1.1 and table 1.2).

Two studies included patients with postoperative stress (Freund 1979, Nuwer 1983), two other studies included patients with postoperative stress or polytrauma (Cerra 1982, Cerra 1983). In most other studies patients with major postoperative stress and/or polytrauma and sepsis are evaluated.

Freund (1979) found that solutions with $22 \%, 35 \%$ and $100 \%$ BCAA in 35 patients undergoing operative injury of moderate severity resulted in nitrogen equilibrium or a slight positive nitrogen balance, while the group receiving dextrose $5 \%$ only was in a mean negative nitrogen balance. The differences between the three groups receiving amino acids were not significant. With mild variations the plasma amino acid patterns in all groups were similar to the normal pattern, even in the group receiving the unbalanced $100 \%$ BCAA solution.

Cerra (1982) found that urinary nitrogen excretion fell by day three and remained low in 15 non-septic post-abdominal surgery patients and patients with multiple traumatic injuries receiving a 35\% BCAA-enriched TPN solution compared with a standard solution containing $15 \% \mathrm{BCAA}$. The group receiving the enriched solution had a significant positive nitrogen balance by day 3 of the 7-day study, whereas the standard group (BCAA $15 \%$ ) received an equivalent positive nitrogen balance only by day 6 .

In another study Cerra (1983) found BCAA administration to result in increased nitrogen retention. This effect was proportional to the BCAA load and started at $0.5 \mathrm{~g} \mathrm{BCAA} / \mathrm{kg} /$ day in a setting of balanced nutritional support. There were no complications or side-effects from high doses of BCAA.

Nuwer (1983) found that skin test reactivity and absolute lymphocyte counts showed a marked improvement indicating an improved immune competence in patients receiving a solution with $45 \%$ BCAA ( $\mathrm{p}<0.03$ ), compared to patients receiving a standard solution with $24.2 \%$ BCAA.

Cerra (1984) confirmed the significant elevation of the absolute lymphocyte counts $(p<0.05$ ), and observed in addition improving plasma transferrin levels and nitrogen balance in 23 postsurgical patients and patients with polytrauma or sepsis receiving an amino acid solution with $45 \%$ BCAA compared with a group that received an amino acid solution with $24 \%$ BCAA. A reversal of anergy to recall skin test antigen occurred in $60 \%$ of the patients receiving the enriched solution and in only 1 patient receiving the standard solution. 
Table 1.1 Types of nutritional support and BCAA content.

\begin{tabular}{|c|c|c|c|c|c|c|}
\hline \multirow[t]{2}{*}{ Author } & \multicolumn{5}{|c|}{ Nutritional support } & \multirow{2}{*}{$\begin{array}{l}\text { Nutritionall treatment } \\
\text { groups. BCAA \% }\end{array}$} \\
\hline & & $\mathrm{N} / \mathrm{cal}$ & $\begin{array}{l}\text { Protein } \\
\mathrm{g} / \mathrm{kg} / \mathrm{day}\end{array}$ & $\begin{array}{l}\text { Glucose } \\
\text { cal/kg/day }\end{array}$ & $\begin{array}{l}\text { Fat } \\
\mathrm{cal} / \mathrm{kg} / \mathrm{day}\end{array}$ & \\
\hline Freund & $\mathbb{1}$ & - & 0 & $6-8$ & $=$ & $0 \%$ \\
\hline \multirow[t]{3}{*}{1979} & 2 & $1: 40$ & 1.0 & $6-8$ & - & $22 \%$ \\
\hline & 3 & $1: 40$ & 10 & $6-8$ & - & $35 \%$ \\
\hline & 4 & $1: 40$ & 1.0 & $6-8$ & - & $100 \%$ \\
\hline Cerra & 1 & $1: 215$ & 1 & 35 & - & $15.5 \%$ \\
\hline 1982 & 2 & $1: 215$ & 1 & 35 & - & $50 \%$ \\
\hline Cerra & 1 & $1: 190$ & 1.0 & 30 & - & $16 \%(0.15 \mathrm{gm} / \mathrm{kg})$ \\
\hline \multirow[t]{3}{*}{1983} & 2 & $1: 150$ & 1.5 & 30 & 7 & $20 \%(0.30 \mathrm{gm} / \mathrm{kg})$ \\
\hline & 3 & $1: 190$ & 1.0 & 30 & 一 & $50 \%(0.50 \mathrm{gm} / \mathrm{kg})$ \\
\hline & 4 & $1: 150$ & 1.5 & 30 & 7 & $50 \%(0.70 \mathrm{gm} / \mathrm{kg})$ \\
\hline Nuwer & 1 & $1: 150$ & 1.5 & 30 & 7 & $24 \%$ \\
\hline 1983 & 2 & $1: 150$ & 1.5 & 30 & 7 & $45 \%$ \\
\hline Cerral & 1 & $1: 150$ & 1.5 & 30 & 7 & $24 \%$ \\
\hline 1984 & 2 & $1: 150$ & 1.5 & 30 & 7 & $45 \%$ \\
\hline Bower & 1 & $1: 150$ & 1.5 & 28 & 9 & $25 \%$ \\
\hline \multirow[t]{2}{*}{1986} & 2 & $1: 150$ & 1.5 & 28 & 9 & 45 o Valine \\
\hline & 3 & $1: 150$ & 1.5 & 28 & 9 & $45 \%$ Leucine \\
\hline Lundholm & 1 & $1: 240$ & 1 & 20 & 20 & $100 \%$ \\
\hline \multirow[t]{2}{*}{1986} & 2 & $1: 240$ & 1 & 20 & 20 & $38 \%$ (only EAA) \\
\hline & 3 & $1: 240$ & $\mathbb{1}$ & 20 & 20 & $15 \%$ \\
\hline Cerra & 1 & $1: 114$ & $1.0-2.0$ & $19-38$ & - & $18 \%$ \\
\hline 1987 & 2 & $1: 114$ & $1.0-2.0$ & $19-38$ & - & $50 \%$ \\
\hline Okada & 1 & $1: 164$ & 1.5 & 40 & - & $22.6 \%$ \\
\hline \multirow[t]{3}{*}{1988} & 2 & $1: 164$ & 1.5 & 40 & - & $36 \%$ (sub.gastr) \\
\hline & 3 & $1: 164$ & 1.5 & 40 & - & $22.6 \%$ \\
\hline & 4 & $1: 164$ & 1.5 & 40 & - & $36 \%$ (tot.gastr) \\
\hline Zhu-ming & 1 & $1: 150$ & 1.2 & 16 & 14 & $186 \%$ \\
\hline 1988 & 2 & $1: 150$ & 1.2 & 16 & 14 & $33.4 \%$ \\
\hline Maldonado & 1 & $1: 100$ & 1.5 & $20-25$ & - & $23 \%$ \\
\hline 1988 & 2 & $1: 100$ & 1.5 & $20-25$ & - & $35 \%$ \\
\hline Freysz & 1 & & 1.8 & 8 & - & $24 \%$ \\
\hline 1989 & 2 & & 1.8 & 8 & 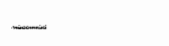 & $41 \%$ \\
\hline
\end{tabular}




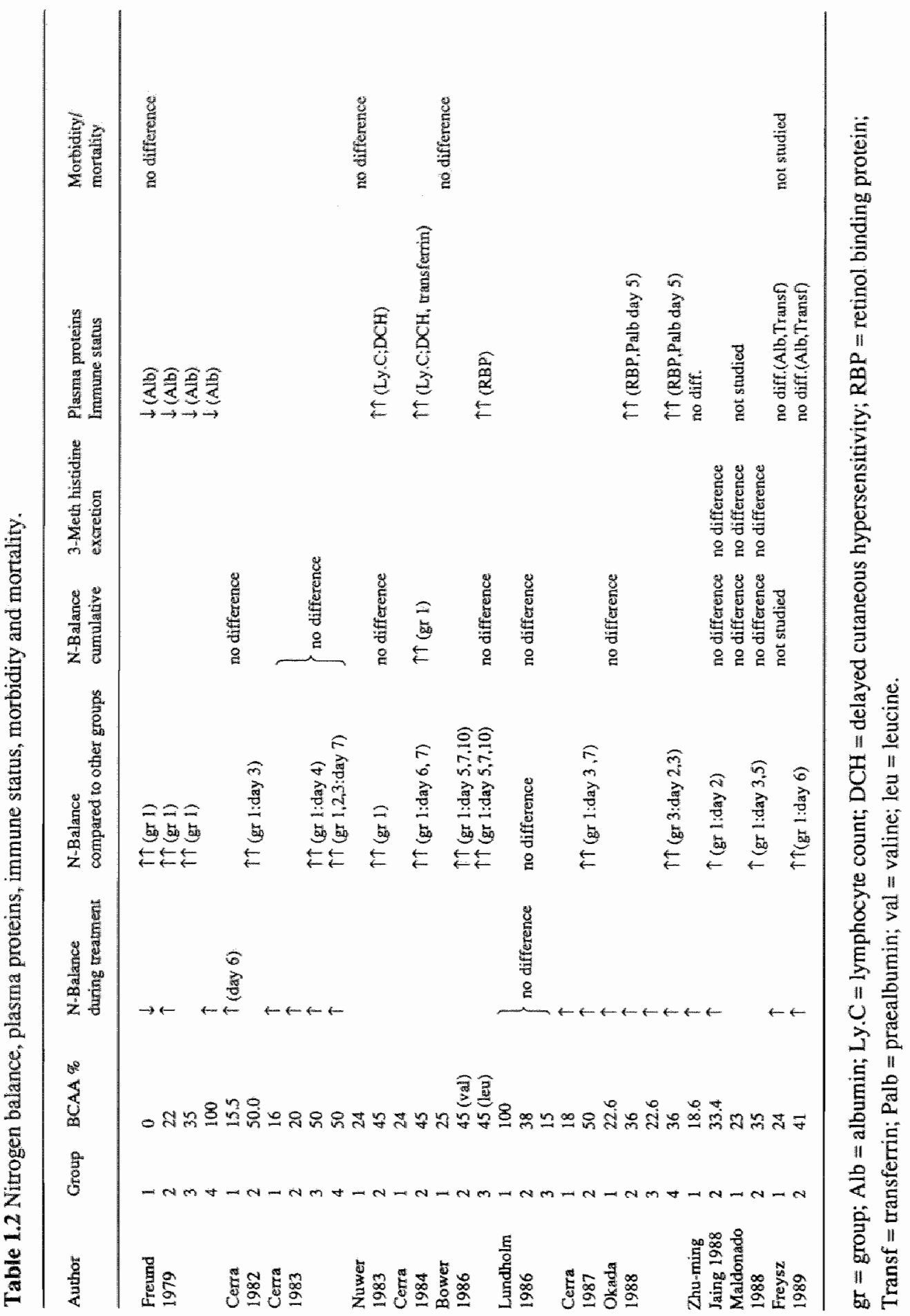


Van Way (1985) observed an increased nitrogen excretion and positive nitrogen balance during a 14-day study in a group of 12 patients receiving either a $25 \%$ BCAA containing solution or $45 \%$ BCAA-enriched (isoleu and val, normal leu). The 3-methylhistidine excretion hardly changed in either group.

Lundholm (1986) reported that two unbalanced aminoacid solutions (1: $35 \%$ essential amino acids and 2: $100 \% \mathrm{BCAA}$ ) resulted in a twofold more negative nitrogen balance than a balanced and complete amino acid solution containing 15\% BCAA. However, the difference disappeared and nitrogen balance approached equilibrium irrespective of the aminoacid composition of the infused solution when nitrogen of blood products was accounted for, indicating the importance to mention the amount of nitrogen intake from blood products when the efficacy of amino acid solutions is tested.

Bower (1986) investigated the nitrogen-sparing qualities of a standard amino acid solution with $25 \%$ BCAA and two amino acid solutions with $45 \%$ BCAA: one primarily with valine, the other with leucine. He observed that nitrogen retention was significantly better on days 5,7 and 10 in both groups of patients receiving the BCAA-enriched solutions, but differences in cumulative nitrogen balance were not statistically significant. There were no differences observed in 3-methylhistidine excretion. The high-valine solution did not support the plasma concentrations of the short turn-over proteins, while the high-leucine solution led to increased plasma concentrations of transferrin, retinol binding protein and prealbumin compared to the high-valine and standard solutions. The standard amino acid solution was superior to the high-valine solution, but not significantly. No improvement in clinical outcome in the groups receiving the branched-chain enriched solutions was observed.

Cerra (1987) evaluating a multi-center trial with 87 patients found no difference regarding the nitrogen-sparing effect between the standard amino acid formula containing $18 \% \mathrm{BCAA}$ and the $50 \% \mathrm{BCAA}$-enriched solution containing equal amounts of leucine, isoleucine and valine. In the BCAA enriched group a significant improvement of nitrogen-balance on day 3-4 and day 7 compared to day 0 was observed. However, when nitrogen ballance was considered as a function of the dose of amino-acids given, the group receiving the 50\% BCAA solution showed a better nitrogen retention, reached nitrogen equilibrium at a lower dose of amino acids and had less urinary nitrogen excretion per gram of nitrogen administered. It appeared as if nitrogen equilibrium in surgical stress was proportionate to the amino acid load over a range of $0.05-0.4 \mathrm{gm} / \mathrm{kg} / \mathrm{day}$ of nitrogen.

Okada (1988) found in 173 patients with gastric cancer undergoing subtotal(86) or total(87) gastrectomy, that the group of patients undergoing total gastrectomy and receiving the $35 \%$ BCAA-enriched solution showed a signifi- 
cantly improved nitrogen balance on days 2 and 3 . Cumulative nitrogen balance in this group of patients was not significantly different from the control group, receiving a $22.6 \% \mathrm{BCAA}$ solution. No difference in nitrogen balance was found in both groups undergoing the subtotal gastrectomy. There were no differences in serum albumin and total protein between the standard and the BCAA-enriched solution in patients undergoing total or subtotal gastrectomy. The short turn-over proteins retinol-binding protein, prealbumin and transferrin were not significantly different between the standard and the BCAA-enriched groups. Plasma values of the BCAA and the ratio of BCAA/AAA were significantly higher and the values of the AAA significantly lower in the groups receiving the BCAA-enriched solution compared to the group receiving the standard amino acid solution. During the observation period no serious complications were seen in either treatment group.

Zhu-ming Jaing (1988) found in 16 patients undergoing subtotal gastrectomy or hemicolectomy no difference in nitrogen balance between a standard amino acid solution containing 23\% BCAA and a 40\% BCAA-enriched amino acid solution. The plasma concentrations of valine and leucine were significantly increased ( $p<0.05$ and $p<0.01$ resp.) 2 days after administration of the solutions enriched with BCAA and throughout the entire postoperative period. Glutamine concentrations decreased in both groups.

Maldonado (1988) studied two isocaloric parenteral nutrition infusions containing $23 \%$ and $35 \%$ of BCAA on nitrogen balance and 3-methylhistidine urinary excretion in fifty-one (51) children. Nitrogen balances at the 5 th day after starting parenteral nutrition were significantly higher than on the first day for all. groups studied $(\mathrm{p}<0.05)$. There were, however, no significant differences in nitrogen balances between patients with trauma or infection or between type of amino acid solution. The 3-methylhistidine excretion in the urine decreased after the onset of trauma and infection, but no differences were found between groups.

Freysz (1989) found that the cumulative nitrogen balances in patients with severe sepsis receiving hypocaloric diets with an amino acid solution containing $24 \%$ or $41 \%$ of BCAA were not significantly different, but at day 6 patients receiving the enriched $\mathrm{BCAA}$ solution were in an anabolic state, while catabolism persisted in the control group. At day 6 the patients receiving the enriched formula had significantly higher plasma levels of valine and the sum of the BCAAs. The sum of aromatic amino acids was significantly higher in the control group, leading to significantly different Fischer-ratios (BCAA/AAA) between groups. Plasma levels of albumin and transferrin were not different between groups. 
Since 1979 BCAA-enriched solutions have been used in prospective (randomized) trials in patients with sepsis, surgical stress and trauma. The studies of Cerra (1987) and Okada (1988) included a large number of patients compared to all other studies consisting of only small groups of patients. With the exception of Lundholm (1986), who found no difference in $\mathrm{N}$-balance during treatment when intake of nitrogen content in bloodproducts was accounted for, all studies reported an improved nitrogen balance, when amino acid solutions were compared with control groups receiving only dextrose. Significant improvement of nitrogen balance in the groups of patients receiving the BCAA-enriched amino acid solutions compared to the groups of patients receiving a standard amino acid solution was reported by Cerra (1982, 1983, 1984), Nuwer (1983), Bower (1986), Okada (1988) and Freysz (1989).

Lundholm (1986), Zhu-ming Jaing (1988) and Maldonado (1988) reported no difference in N-balance when the BCAA-enriched regimen was compared with an amino-acid solution containing a standard amount of BCAA.

Cerra (1987) found that BCAA-enriched amino-acid solutions resulted in better nitrogen retention, reaching nitrogen equilibrium at a lower dose of amino acids. However, it must be stressed that in this study significant differences in nitrogen balance were only found in the group receiving the enriched BCAA solution when the levels of day 3-4 and day 7 were compared with day 0 of the study. No differences were found when nitrogen balances of the enriched regimen were compared with the standard amino acid solution.

Urinary 3-Methylhistidine excretion studied as a parameter for muscle degradation, decreased in most studies. No differences were found between the various BCAA solutions. This suggests that muscle proteolysis is not influenced by the nutritional regimen.

Immune function was investigated by Nuwer (1983) and Cerra (1984). Both found a significant increase in absolute lymphocyt counts and delayed cutaneous hypersensitivity in the group of patients receiving BCAA enriched nutrition.

Freysz (1989) found no difference in skin test reactivity between a BCAA enriched and a standard regimen.

Bower (1986) and Cerra (1984) found an increase of short turnover proteins such as transferrin, pre-albumin and retinol-binding protein, especially in the BCAA enriched solution, whereas Okada (1988) found these short half-life proteins to increase significantly in both nutritional regimens.

Despite these clinical trials there is an ongoing controversy with respect to the value of BCAA enrichment of TPN solutions. The reasons for this ongoing controversy are manifold: the favourable effect of the BCAA on protein synthesis 
in in-vitro experiments have not been confirmed in in-vivo experiments. Furthermore, it is obvious that the mere evaluation of $\mathrm{N}$-balances will not suffice to prove efficacy of a -presumed more efficient - nitrogen source in artificial nutrition and finally, the groups of patients in clinical studies are often very small and heterogeneous.

Most studies do not furnish much information regarding the clinical characteristics of the population under study: Mortality and morbidity are often not mentioned or it is simply stated that there is no difference in clinical outcome between groups receiving the various nutritional regimens. It is therefore impossible to ascertain whether the observed improvements are due to $\mathrm{BCAA}$ enrichment of the amino-acid solution or are the result of clinical differences between groups. 


\section{REFERENCES}

Adibi SA. Metabolism of branched-chain amino acids in altered nutrition. Metabolism 25:1287$1302,1976$.

Adibi SA. Roles of branched-chain amino acids in metabolic regulation. I Lab Clin Med $95: 475-484,1.980$.

Askanazi J, Carpentier $Y$, Elwyn D, et al Influence of total parenteral nutrition on fuel utilization in injury and sepsis. Ann Surg 191:40-46,1980.

Benedict FG. A study of prolonged fasting. Carnegie Institution of Washington, 1915.

Blackburn GL, Moldawer LL, Usui S, et al Branched-chain amino acid administration and metabolism during starvation, injury and infection. Surgery 86:307-315, 1979 .

Bonau RA, Ang SD, Jeevanandam M, Daly J. High branched-chain anino acid solutions: relationship of composition to efficacy. JPEN 8:622-627,1984.

Bower RH, Kern KA, Fischer JE. Use of a branched-chain amino acid enriched solution in patients under metabolic stress. Am J Surg 49:266-270,1985.

Bower RH, Muggia-Sullam M, Vallgren $\mathrm{S}$, et al. Branched-chain amino acid enriched solutions in the septic patient. Ann Surg 203:13-20,1986.

Buse $\mathrm{MG}$, Reid SS. Leucine. A possible regulator of protein turnover in muscle. J Clin Invest $56: 1250-1261,1975$.

Cahill Jr GF. Starvation in man. New Engl Med 282:668-675,1970.

Cerra $\mathrm{FB}$, Siegel $\mathrm{JH}_{4}$, Border JR, et al The hepatic failure of sepsis: cellular versus substrate. Surgery 86:409-422,1979.

Cerra FB, Upson D, Angelico R, et al Branched-chains support postoperative protein synthesis. Surgery 92:192-198,1982.

Cerra FB, Mazuski J, Teasley K, et al Nitrogen retention in critically ill patients is proportional to the branched-chain amino acid load. Crit Care Med 11:775-778,1983.

Cerra FB, Mazuski JE, Chute E, et al Branched-chaïn metabolic support. Ann Surg 199:286291,1984 .

Cerra FB, Blackburn G, Hirsch J, et al The effect of stress level, amino acid formula and nitrogen dose on nitrogen retention in traumatic and septic stress. Ann Surg 205:282-287,1987.

Chua BHL. Siehl DL, Morgan HE. Effect of leucine and metabolism of branched-chain amino acids on protein turnover in heart. J Biol Chem 254:8358-8362,1979,

Chua BHL, Siehl DL, Morgan HE. A role for leucine in regulation of protein turnover in working rat hearts. Am J Physiol 239 (Endocrinol Metab 2) E 510-514, 1980.

Clowes Jr GHA, Martin H, Walji S, et al Blood insuline responses to blood glucose levels in high output sepsis and septic shock. Am J Surg 135:577-583,1978.

Clowes JR GHA, O'Donnell TF, Blackburn GL, Maki TN. Energy metabolism and proteolysis in traumatized and septic man. Surg Clin North Am 56:1169-1184,1976.

Clowes Ir GHA, Randall HT, Cha CJ. Amino acid and energy metabolism in septic and traumatized patients. JPEN 4:195-205,1980.

Clowes GMA, Mc Dermott WV, Williams LF, Loda M, Menzoian JO, Pearl R. Amino acid clearance and prognosis in surgical patients with cirthosis. Surgery 96:675-684,1984.

Echenique MM, Bistrian BR, Moldawer LL, et al Improvement in amino acid use in the critically ill patient with parenteral formulas enriched with branched-chain amino acids. Surg Gyn Obst 159:233-241,1984. 
Felig $\mathrm{P}_{\text {; }}$ Marliss E, Pozefski $\mathrm{T}$, Cahill Jr GF. Amino acid metabolism in the regulation of gluconegenesis in man. Am J Clin Nutr 23:986-992,1970.

Freund $H R_{,}$Yoshimura $N$, Lunetta $L$, Fischer $J E$. The role of the branched-chain amino acids in decreasing muscle catabolism in vivo. Surgery 83:611-618,1978.

Freund HR, Hoover HC, Atamian S, Fischer JE. Infusion of the branched-chain amino acids in postoperative patients. Ann Surg 190:18-23,1979.

Freund $H \mathbb{R}$, Yoshimura N, Fischer JE. The effect of branched-chain amino acids and hypentonic glucose infusions on post injury catabolism in the rat. Surgery 87:401-408, 1980.

Freund HR, James JH, Fischer IE. Nitrogen-sparing mechanisms of singly administered branched chain amino acids in the injured rat. Surgery 90:237-243,1981.

Freund HR, Dann EJ Burns $F$, et al. Systolic properties of normal and septic isolated rat hearts. Arch Surg 1.20:483-488,1985 .

Freund HR, Muggia-Sullam M, Lafrance R, et al Muscle Prostaglandon production in the rat. Arch Surg 120:1037-1039,1985 .

Freys: $2 \mathrm{M}_{3}$ Caillard $\mathrm{B}$, Desgres $\mathrm{J}$, et al Are branched-chain amino acids beneficial for nutrition of severe surgical patients with sepsis? Clin Nutr 8:61-67,1989.

Fulks RM, Li JB, Goldberg AL. Effects of insuline, glucose and amino acids on protein turnover in rat diafragm. J Biol Chem 250:290-298,1975.

Garber AJ, Kar』 IE, Kipnis DM. Alanine and glutanine synthesis and release from skeletal muscle.. J Biol Chem 251:836 843,1976.

Gimmon Z, Freund HR, Fischer JE. The optimal branched-chain to total amino acid ratio in the injury-adapted amino acid formulation. JPEN 9:133-138,1985.

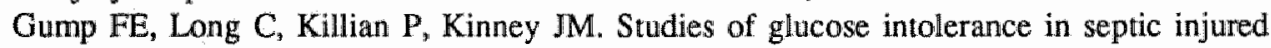
patients. J Trauma 14:378-388,1974.

Harper AE. Dispensable and indispensible amino acid interrelationships, p.105-121 in "Amino acids. Metabolism and medical applications", ed. Blackburn GL et al,1984.

Hasselgren Pl, James JH, Wamer BW, et al. Protein synthesis and degradation in skeletal muscle from septic rats. Arch Surg 123:640-644,1988.

Hasselgren $P$, Lafrance $R$, Pedersen $P_{\text {, }}$ et al Infusion of a branched-chain amino acid-enriched solution and a-ketoisocaprioc acid in septic rats: Effects on nitrogen balance and skeletal muscle protein turnover. JPEN 12:244-249,1988.

Ichihara $A$, Noda $C$, Ogawa $K$. Control of leucine metabolism with special reference to branched-chain amino acid transaminase iso-enzymes. Adv Enzyme Regul 11:155-166, 1973.

Imamura M, Clowes JR GHA, Blackbum GL, et al Liver metabolism and gluconeogenesis in trauma and sepsis. Surgery 77:868 880,1975.

Jaing Z, Zhang F, Zhu Y, et al Evaluation of parenteral nutrition in the postoperative patient. Surg Gyn Obst 166:115-120,1988.

Kem KA, Bower RH, Atamian $S_{*}$ et al The effect of a new branched-chain-enriched amino acid solution on postoperative catabolism. Surgery $92: 780-785,1982$.

Kikuchi T, Fukudome S, Ikamoto H, et al Effect of enrichment of infusion solutions with branched-chain amino acids in parenteral nutrition in rats. J Nutr Sci Vitaminol 33:6373,1987 .

Kinney JM, Duke JH, Long Cl, Gump FE. Tissue fuel and weight loss after injury. J Clin Path 23, suppl.(Royal coll.Path), 4:65-72,1970. 
Lindberg BO, Clowes GHA. The effects of hyperalimentation and infused leucine on the thmino acid metabolism in sepsis: an experimental study iv wivo. Surgery $90.278-288,1981$.

Lundholm $\mathrm{K}$, Bennegard $\mathrm{K}$. Wichstrom $\mathrm{F}$, Lindmark $\mathrm{L}$. Is it possible to evaluate the efficacy of amino acid solutions after major surgical procedures or acciderntal injuries? Evaluation in a randomized and prospective study. JPEN 10:29-33,1986.

Maldonado J, Faus MJ, Bayes R, et al Apparent nitrogen balance and 3 methylhistidine urinary excretion in intravenously fed children with trauma and infection. Eur I Clin Nutr 42:93100,1988 .

Markovitz L, Hasin Y, Dana EJ, et al The different effects of leucine; isoleucine and valine on systolic properties of the normal and septic isolated tat heart. J Surg Res 38:231-236, 1985.

Morgan $\mathrm{HE}$, Chua BHL. Leucine as a regulator of protein synthe-sis and degradation in heart muscle. Branched-chain amino-and ketoacids in health and disease, pp 15-21 (Karger, Basel 1984).

Mori $\mathrm{E}$, Hasebe M, Kobayashi K. Effect of total parenteral nutrition enriched in branched chain amino acids on metabolite levels in septic rats. Metabolism 37:824-830,1988.

Munro HN. Metabolism and functions of amino acids in man Overview and synthesis.p.1-12 in "Amino acids". Metabolism and medical applications", ed. Blackbum GL et al, 1984.

Nachbauer CA, James $\mathrm{JH}_{*}$ Edwards $\mathrm{LL}$, et al. Infusion of branched chain-enriched amino acid solutions in sepsis. Am J Surg 147,743-752,1984.

Nordenström J, Carpentier Y, Askanasi J, er al. Free fatty acid mobilization and oxidation during total parenteral nutrition in trauma and infection. Ann Surg 198: 725-735, 1983.

Nuwer N, Cerra FB, Shronts EP, et al. Does modified amino acid total parenteral nutrition alter immune-response in high level surgical stress? JPEN 7:521-524,1983.

Odessey R, Khairallah EA, Goldberg AL. Origin and possible significance of alanine production by skeletal muscle. J Biol Chem 249:7623-7629,1974.

Okada A, Mori S, Totsuka M, et al. Branched-chain amino acids metabolic support in surgical patients: a randomized, controlled trial in patients with subtotall or total gastrectomy in 16 Japanese institutions. JPEN 12:332-337,1988.

Owen OE, Morgan AP, Kemp HG, Sullivan JM, Herrera MG, Cahill GF. Brain metabolism during fasting. J Clin Inv 46:1589-1595,1967.

Pedersen P, Li S, Hasselgren P, et al. Administration of balanced or BCAA-enriched amino acid solution in septic rats. Ann Surg 208:714-720,1988.

Ryan NT, George BC, Egdahl DH, Egdahl RH. Chronic tissue insulin resistance following hemorrhage shock. Ann Surg 180:402-407,1974.

Sapir DG, Stewart PM, Walser M, et al. Effects of ketoleucine and ofleucine on nitrogen metabolism in post-operative patients. Branched-chain amino and ketoacids in health and disease, pp. 348-360 (Karger, Basel 1984).

Shenkin A, Neuhäuser M, Berström J et al. Biochemical changes associated with severe trauma. Am J Clin Nutr 33:21 19-2127,1980.

Soeters PB. Amino acid administration in trauma and sepsis. Lecture Pavia . Italy 1985.

Souba WW, Smith RJ, Wilmore DW. Glutamine metabolism by the intestinal tract, JPEN 9:"608-617, 1985 .

Souba WW, Klimberg VS, PJumley DA, Salloum RM, Flynn TC, Bland KI, Copeland EM. The role of glutamine in maintaining a healthy gut and supporting the metabolic response to injury and infection. J Surg Res 48:383-391,1990. 
Tischler ME, Desautels M, Goldberg AL. Does leucine, leucyl-tRNA or some metabolite of leucine regulate protein synthesis and degradation in skeletal and cardiac muscle? I Biol Chem 257:1613-1621;1982.

Van Way CW, Moore EE, Allo M, et al. Comparison of total parenteral mutrition with 25 per cent and 45 per cent branched-chain amino acids in stressed patients. Ann Surg 51:609616,1985 .

Walser M. Therapeutic aspects of branched-chain amino acids and ketoacids. Clinical Science 66:1-15,1984.

Wickterman KA, Chaudry IHG, Bauc AE. Studies of peripheral glucose uptake during sepsis. Arch Surg 114:740-745,1979.

Wilmore DW, Goodwin CW, Aulick LH, et al. Effect of injury and infection on visceral metabolism and circulation. Ann Surg 192:491-500,1980.

Windmueller HG. Glutamine utilization by the small intestine. Adv Enzymol 53:201-237,1982. 


\section{Chapter 2}

\section{Present study, patients and methods}

If BCAA enrichment of amino acid solutions would influence protein metabolism in patients with sepsis and trauma positively, not only the nitrogen-sparing effects should be measured, but also plasma amino acid profiles, serum proteins and parameters of the immunologic state of the patient. However, most studies only deal with the nitrogen sparing effect of BCAA-enrichment on nitrogen balance.

The ultimate goal of BCAA enrichment of TPN solutions in patients with sepsis and trauma is to improve clinical outcome and reduce mortality. Data concerning morbidity and mortality are rare. Some studies simply state that no differences in clinical outcome were observed, while in most studies these parameters are not at all evaluated.

In many studies patients with different levels of postoperative stress and sepsis and polytrauma patients were included, but were combined to judge the effects of nutritional repletion. We therefore analyzed the results after stratification for the level of energy expenditure and metabolic stress as well as grades of sepsis to obtain well balanced groups for the evaluation of BCAA-enrichment in nutritional regimens.

On the basis of the above premises we designed the following study.

\section{AIMS OF THE STUDY}

1 The primary goal of the study was, to investigate whether the administration of a TPN solution containing an amino acid fraction enriched with branchedchain amino acids to patients with sepsis and/or trauma would result in an improvement of nitrogen sparing if compared to a TPN solution containing an amino acid fraction of conventional composition. 
Secondary goals of this study were:

2 To investigate whether clinical outcome would improve as a result of BCAA. administration

3 To analyse plasma amino acid profiles in patients with sepsis and metabolic stress

4 To analyse the effects of infusion of amino acid solutions on plasma amino acid patterns.

5 To evaluate scoring systems of sepsis and morbidity.

\section{PATIENTS AND METHODS}

\section{Patients}

Patients with sepsis and patients with metabolic stress were eligible to enter the study.

Sepsis was defined as the presence of a combination of some of the following critiria accompanying the presence of a clinically manifest septic focus: spiking temperature, hyperventilation, tachycardia, elevated white blood cell count, decreased blood pressure, diminished urine output and positive blood cultures.

Patients were considered metabolically stressed if they had suffered multiple trauma, undergone operation for ruptured aortic aneurysm, severe non-septic pancreatitis, major gastro-intestinal surgery or non-septic enterocolitis.

Patients were withdrawn from the study if renal failure progressed to a level necessitating protein restriction or if fluid restriction prohibited the use of the study solution.

The study was reviewed, approved and carried out according to the rules of the Human Studies Committee of the University of Maastricht. 


\section{Stratification and randomisation}

Patients were stratified as follows:

\section{Septic patients}

Septic patients were stratified for age and localization (abdominal or pulmonary) of the septic focus

$$
\text { Group A: } 16 \text { to } 65 \text { years } \quad \ldots \ldots \text { abdominal sepsis }
$$

Group B: 66 years or older - . . . . abdominal sepsis

$$
\text { ..... pulmonary sepsis }
$$

\section{Metabolically stressed patients}

Metabolically stressed patients were stratified for age. Each subgroup of patients was randomized by the hospital pharmacy to receive the conventional or the BCAA-enriched solution. Both solutions were delivered to the ward labeled "BCAA study solution". Thus double blinding was secured.

\section{Solutions}

Both amino acid-dextrose mixtures contained equal amounts of amino acid nitrogen/L, derived in the standard solution from a balanced synthetic amino acid solution (Synthamin $14^{\circledR}$ ), and derived in the branched-chain amino acid enriched solution from a more concentrated balanced synthetic amino acid solution (Synthamin $17^{\circledR}$ ) and a $4 \%$ BCAA solution containing equimolar amounts of valine, isoleucine and leucine. The standard solution contained 15.6\% BCAA and the BCAA solution contained 50.2\% BCAA of total nitrogen (table 2.1).

Each mixture contained $20 \%$ glucose $(800 \mathrm{cal} / \mathrm{L})$. The resulting glucose calorie to nitrogen ratio was $161: 1$. Both nutritional support solutions were composed according to the standards of today's practice, providing sufficient minerals, trace elements and vitamins. At least twice per week $500 \mathrm{ml}$ of a $10 \%$ fat emulsion was administered, but if caloric needs exceeded 2000 calories per day, fat emulsions were given daily.

\section{Planned nutritional support}

Caloric intake was calculated to meet basic energy expenditure according to Harris-Benedict, augmented with $10 \%$ specific dynamic action of food and a stress percentage as suggested by Kinney (1970), ranging from 10-60\% (table 
Table 2.1 Amino acid content per liter of the study solutions.

BCAA Standard

\section{Essential amino acids}

$\begin{array}{lll}\text { L-leucine } & 6.10 \mathrm{~g} & 1.80 \mathrm{~g} \\ \text { L-phenylalanine } & 1.25 \mathrm{~g} & 1.80 \mathrm{~g} \\ \text { L-methionine } & 1.20 \mathrm{~g} & 1.70 \mathrm{~g} \\ \text { L-lysinehydrochloride } & 1.50 \mathrm{~g} & 2.10 \mathrm{~g} \\ \text { L-isoleucine } & 5.90 \mathrm{~g} & 1.40 \mathrm{~g} \\ \text { L-valine } & 5.30 \mathrm{~g} & 1.30 \mathrm{~g} \\ \text { L-histidine } & 0.90 \mathrm{~g} & 1.30 \mathrm{~g} \\ \text { L-threonine } & 0.80 \mathrm{~g} & 1.20 \mathrm{~g} \\ \text { L-tryptophan } & 0.40 \mathrm{~g} & 0.50 \mathrm{~g}\end{array}$

Non-essential amino acids

L-alanine $4.20 \mathrm{~g}$

$6.10 \mathrm{~g}$

L-glycine

$4.20 \mathrm{~g}$

$6.10 \mathrm{~g}$

L-arginine

$2.10 \mathrm{~g}$

$3.10 \mathrm{~g}$

L-proline

$0.80 \mathrm{~g}$

$1.20 \mathrm{~g}$

L-tyrosine

$0.80 \mathrm{~g}$

$1.20 \mathrm{~g}$

Total amino acids

$34.70 \mathrm{~g}$

$29.70 \mathrm{~g}$

Total nitrogen

$5.01 \mathrm{~g}$

$4.98 \mathrm{~g}$

Table 2.2 Stress factors

$\begin{array}{ll}\text { Elective surgery, postoperative } & 5 \% \\ \text { Soft tissue trauma } & 10-15 \% \\ \text { Peritonitis } & 10-20 \% \\ \text { Fracture, long bone } & 10-25 \% \\ \text { Multisystem trauma } & 20-50 \% \\ \text { Mild infection } & 0-20 \% \\ \text { Moderate infection } & 20-40 \% \\ \text { Severe infection } & 40-60 \%\end{array}$


2.2) resulting in sufficient caloric intake to cover actual total energy expenditure. Patients were not allowed any additional food. Blood and blood products were administered as required.

\section{Monitoring of the study patients}

\section{Laboratory determinations}

On day 0 , day 4 and day 7 of the study venous blood samples were drawn for determination of: Hemoglobin (mmol/1); Haematocrit $(\%)$; Leucocytes $\left(10^{9} / 1\right)$; Bandshaped leucocytes $\left(10^{9} / 1\right)$; Lymphocytes $\left(10^{9} / 1\right)$; Thrombocytes $\left(10^{9} / 1\right) ;$ Glucose (mmol/l); Ureum (mmol/l); Creatinine (mmol/l); Alk.fosf. (U/l); GTP (U/l); SGOT (U/l); SGPT (U/l); LDH (U/1); Bilirubin ( $\mu$ mol/l); Tot. protein $(\mathrm{g} / \mathrm{l})$; Albumin (g/l); Pre-albumin (g/l).

In addition, bloodsamples were drawn on day 0 , day 4 and day 7 of the study for amino acid analysis. For this determination $1.0 \mathrm{ml}$ of plasma was deproteinized by addition of $40 \mathrm{mg}$ of sulfosalicylic acid. After protein precipitation samples were centrifuged $\left(3.000 \mathrm{xg}, 10 \mathrm{~min}, 4^{\circ} \mathrm{C}\right.$ ) the supernatants were passed through a millipore filter ( $0.22 \mu \mathrm{m}$ pore size) before storage at $-70{ }^{\circ} \mathrm{C}$ until analysis. Amino acids were determined in $30 \mu \mathrm{l}$ of each sample by a LKB 4400 automated amino acid analyser, employing lithium buffers and ninhydrin detection.

Urinary 3-methylhistidine content was analyzed after hydrolysis on a LKB automated amino acid analyser (LKB Biochrom Ltd, Cambridge,UK). Urinary nitrogen excretion was analyzed using the Kjeldahl method. Nitrogen balances were estimated by subtracting urinary nitrogen plus a correction factor for faecal and insensible losses from total nitrogen intake. Furthermore, a correction for accumulation or loss of urea was carried out, assuming the distribution volume for urea being $60 \%$ of body weight. Nitrogen in plasma and albumin was considered protein available for metabolic processing and was therefore accounted for in nitrogen balances.

\section{Morbidity-parameters}

Organ function was assessed using the scoring method as proposed by Stevens (1983). Morbidity was assessed by scoring four key organ systems and calculated by squaring the assigned values given to the three organ systems with the most severely disrupted functions. The scoring system was adapted to fit local treatment policies, e.g. the use of ventilatory support would not always reflect the presence of respiratory insufficiency and scoring respiratory function was therefore adapted. Similar adjustments were made for scoring renal function ( creatinine clearence with each patient as his own control was used instead of plasma 
creatinine levels) and circulatory function (grouping of the Stevens scores to compensate for the use of dopamine to improve tissue perfusion, rather than to treat hypotension). Although we realise that in a few patients hyperbilirubinemia may have other origins than impaired liver functions, we considered plasma bilirubin levels adequate parameters of liver function. The scoring of organ functions is summarized in table 2.3. In each organ system high scores represent organ function impairment, while low scores indicate a more normal function. Organ function scores were assessed on days 0,4 and 7 .

\section{Metabolic stress}

To estimate the severity of metabolic stress, the catabolic index was used as proposed by Bistrian (1979).

This index considers urinary urea excretion as consisting of an obligatory portion derived from dietary protein, and a portion that is derived from endogenous protein catabolism. The catabolic index amounts to 24-hour urinary urea nitrogen excretion - $(0.5 \times$ dietary $\mathrm{N}$-intake +3 grams), where it is assumed that $50 \%$ of protein intake is utilized and that the obligatory urine nitrogen excretion amounts to 3 grams.

In this study the catabolic indices were somewhat higher than originally described by Bistrian because total urinary nitrogen values, rather than urea nitrogen values were available.

The patients were divided in 3 groups of metabolic stress:

1. Mild catabolic stress: < 3 grams

2. Moderate catabolic stress: $3-8$ grams

3. Severe catabolic stress: $>8$ grams.

\section{Grading of sepsis}

Sepsis was graded using the method as proposed by Elebute and Stoner (1983). This scoring system consists of 4 chapters (table 2.4 ):

\section{Local effects of sepsis}

2. Pyrexia

3. Secundary effects of sepsis

4. Laboratory data

Sepsis scores were grouped in three categories
1. mild sepsis
ES score < 10
2. moderate sepsis
ES score 10 - 20
3. severe sepsis
ES score $>20$ 


\section{Respiratory function}

Respiratory function was defined according to the respiratory support the patients needed:

0. No support

1. Spontaneous breathing with oxygen enrichment up to $30 \%$

2. Spontaneous breathing with oxygen entichment over $30 \%$

3. Mechanical ventilation with less than $35 \%$ oxygen

4. Mechanical ventilation with more than $35 \%$ oxygen or PEEP.

If the ratio of arterial partial oxygen pressure ( $\mathrm{k}$ Pascal) over oxygen fraction of inspired air $(\%)$ was under 40 we considered the support insufficient and added 1 to the original score.

\section{Circulatory function}

Circulatory function was categorized in 3 scores:

0. No impaired circulatory function (stable blood pressure)

2. Moderate circulatory insufficiency (stable blood pressure with more than normal fluid support and/or dopamine/dobutamine administration.

4. Severe circulatory insufficiency (labile blood pressure, increasing fluid needs and/or increasing doses of dopamine/dobutamine).

Myocardial infarction was excluded from the scoring.

\section{Renal function}

Renal function was assessed using creatinine clearence and expressed as a percentage of predisease levels, that were derived from a nomogram that considers serum creatinine concentrations and weight,age and sex (Siersbaek, 1971).

Five levels of renal function were discerned:
0. Creatinin clearance
$>100 \%$
1. Creatinin clearance
$75-100 \%$
2. Creatinin clearance
$30-75 \%$
3. Creatinin clearance
$<30 \%$
4. Creatinin clearance
Dialysis needed.

\section{Liver function}

Liver function scores were derived from plasma total bilirubin levels. Primary hepatobiliary disease was excluded.

Five categories were defined as follows:
0. $0-17$
1. $17-34$
$\mu$ mol/Liter
2. $34-68$
Hmol/Liter
3. $68-136$
Hmol/Liter
4. over 136
$\mu \mathrm{mol} / \mathrm{Liter}$
$\mu$ mol/Liter. 
Table 2.4. The Ellebute and Stoner sepsis grading using 4 classes of attribute.

\section{1 local effects of tissue infection}

Wound infection with discharge/enterocutaneous fistula

Requiring only light dressing, twice daily

Requiring to be dressed with a pack, dressing needed to be changed more than twice daily, requiring application of a bag and/or requiring suction

Peritonitis

localized peritonitis

generalized peritonitis

Chest infection

clinical or radiological signs of chest infection without productive cough. 2 as above with a cough producing purulent sputum 4

full clinical manifestations of lobar/bronchopneumonia 6

Deep-seated infection (e.g.subphrenic abscess, pelvic abscess, 6 empyema thoracis, acute/chron. osteomyelitis

2 Pyrexia (oral temperature)

Maximum daily temperature $\left({ }^{\circ} \mathrm{C}\right)$ :

Minimum daily temperature above $37.5^{\circ} \mathrm{C}$

If 2 or more temperature peaks above $38.4^{\circ} \mathrm{C}$ in 1 day

\section{3 secondary effects of sepsis}

obvious jaundice ( without hepatobiliary disease)

metabolic acidosis compensated

uncompensated

renal failure

gross disturbance of mental orientation/level of consciousness and /or

focal neurological

manifestations of sepsis bleeding diathesis (dissem, intravasc. coagulation)

\section{4 laboratory data}

blood culture

single positive culture

two or more positive cultures separated by $24 \mathrm{~h}$.

one positive culture + history of invasive procedure

one positive culture + cardiac murnur and/or tender enlarged spleen. 


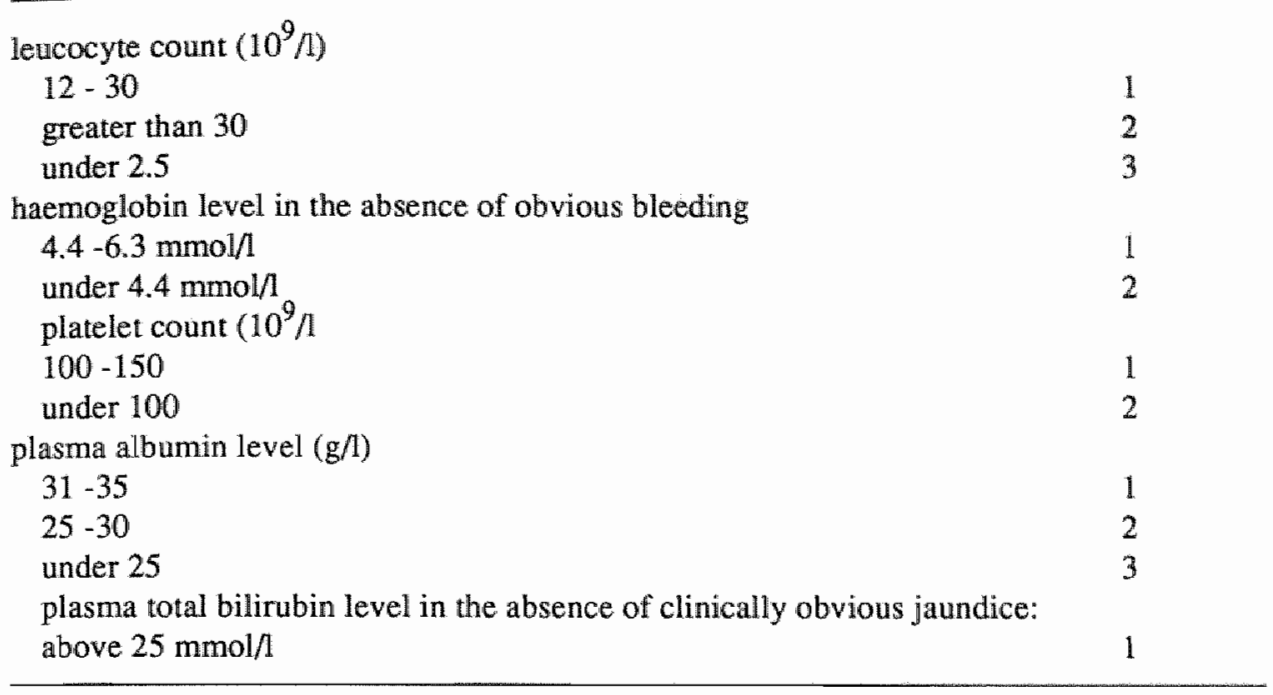

\section{Study design}

The study was limited to 7 days. On day 0 , day 4 and day 7 blood samples were drawn for determination of plasma amino acid patterns and biochemistry. Each day, starting on day 0,24 hour urine was collected for nitrogen and 3-methylhistidine excretion. Furthermore, Bistrian catabolic indices (1979) and Elebute and Stoner sepsis scores (1983) were calculated daily. Finally, mortality was recorded as early sepsis-related if death in overwhelming sepsis occurred within the 7-day study period, as late sepsis-related if death occurred under septic conditions after the study period, or as not sepsis related.

\section{Statistical considerations}

A $30 \%$ reduction of a -20 gram cumulative nitrogen balance in 1 week, with a standard deviation of 10 grams was considered a clinically significant result.

To demonstrate such a result with alpha $=0.05$ and beta $=0.1$ approximately 45 patients per study arm were calculated to be necessary.

An ANOVA procedure was used for comparison of the distribution of values between the different trial groups, with Scheffe's test for multiple ranges to identify the differing groups. Results of the organ function score distribution were evaluated using the Chi square test. 


\section{REFERENCES}

Bistrian BR. A simple technique to estimate severity of stress. Surg Gyn Obst 148:675-678, 1979.

Elebute EA, Stoner HB. The grading of sepsis. Br J Surg 70:29-31,1983.

Kinney IM, Duke JH, Long CL, Gump FE. Tissue fuel and weight loss after injury. J Clin Path 23, Suppl. (Royal Coll Path), 4:65-72,1970.

Stevens LE. Gauging the severity of surgical sepsis. Arch Surg 118:1190-1192,1983. 


\section{Chapter 3}

\section{Branched-chain amino acid (BCAA) enrichment of total parenteral nutrition (TPN) fails to induce nitrogen sparing and alter clinical outcome of sepsis and trauma}

\section{SUMMARY}

Administration of extra branched-chain amino acids (BCAA) has been associated with a nitrogen sparing effect in septic and traumatized patients. Whether nitrogen sparing is associated with decreased morbidity and mortality is unknown. We therefore undertook a prospective, randomized, double blind trial investigating the effects of BCAA enrichment of a total parenteral nutrition (TPN) regimen on nitrogen balance, 3-methylhistidine excretion, morbidity as evidenced by disturbances in organ function, severity of sepsis, and mortality. One-hundred and one patients entered the study, 52 received a standard TPN solution, 49 a BCAA enriched solution. Both groups received $30 \mathrm{KCal} / \mathrm{kg}$ body weight, $15 \%$ fat calories and 0.17 grams nitrogen $/ \mathrm{kg}$ body weight. In the BCAA enriched group, patients received $0.56 \mathrm{~g} \mathrm{BCAA} / \mathrm{kg}$ body weight ( $50.2 \% \mathrm{BCAA}$ ). Standard group patients received $0.18 \mathrm{~g} \mathrm{BCAA} / \mathrm{kg}$ body weight (15.6\% BCAA). Nitrogen balances and 3-methylhistidine excretion were not significantly different between groups. Although morbidity scores tended to decrease during the study no difference was observed between groups. Mortality (early or late), sepsis or stress related, did not differ significantly between groups. We were not able to confirm the reported beneficial effects of BCAA enriched TPN solutions for use in septic and traumatized patients. 


\section{NTRODUCTION}

In an effort to reduce catabolism and loss of body mass during sepsis or after severe injury a parenteral nutrition regimen has been advocated in which the amino acid component consists of $45-50 \%$ of branched-chain amino acids (BCAA), compared with $15-20 \%$ in conventional regimes.

Transamination of BCAA occurs chiefly at extra hepatic sites because transaminase activity in the liver is low (Adibi 1975). The resulting branched chain keto acids (BCKA) are released into the circulation only in very limited quantities. They are irreversibly degraded by $\mathrm{BCKA}$ dehydrogenase, a rate limiting enzyme in the breakdown of BCAA, chiefly located in liver, muscle, adipose tissue, kidney and brain. As a result, BCAA are degraded largely in muscle and adipose tissue. Because BCKA dehydrogenase activity in muscle is regulated by the energy charge and the energy charge has been reported to be low (Clowes 1974, O'Donnell 1976, Siegel 1979), BCAA degradation may be enhanced during severe sepsis and trauma. BCAA enrichment may also improve the precursor amino acid pattern for hepatic protein synthesis which is characterized during severe sepsis by decreased plasma BCAA levels and increased aromatic amino acid levels (AAA) (Mizock 1985). In vitro studies demonstrate that BCAA, especially leucine, promote protein synthesis and BCKA inhibit protein degradation (Buse 1975). These reasons may provide a rationale for BCAA enrichment of TPN solutions.

Several clinical studies have examined the effects of BCAA enrichment of TPN solutions in sepsis and trauma (Cerra 1982, Nuwer 1983, Cerra 1984, Bower 1986, Cerra 1987, Okada 1988, Jaing 1988) but most were small without accurate patient descriptions. No studies have established a possible beneficial effect on morbidity and mortality in addition to the study for nitrogen sparing or effects on plasma proteins. We have, therefore, undertaken a prospective, randomized double blind trial in septic and traumatized patients to confirm the nitrogen sparing effects of the BCAA enrichment and to establish the effects of such enrichment on outcome, measured through morbidity and mortality. The study was reviewed and approved by the Human Studies Committee of the University Hospital, Maastricht. 


\section{PATIENTS AND METHODS}

\section{Patients}

Septic and metabolically stressed patients were eligible to enter the study. Sepsis was defined as the presence of a combination of the following criteria: spiking temperature, hyperventilation, tachycardia, elevated white blood cell count, decreased blood pressure, diminished urine output and positive blood cultures. A clinically manifest septic focus and signs of septic shock were considered obligatory. Patients were considered metabolically stressed if they had: suffered multiple trauma, undergone operation for ruptured abdominal aortic aneurysm, severe non-septic pancreatitis, major gastro-intestinal surgery or non-septic enterocolitis. Because it may be argued that under conditions without significant metabolic stress the presumed need for additional BCAA is absent and that in extremely ill patients no reasonably stable study conditions may be reached, patients suffering stress ranging from 20-50\% according to the criteria of Kinney (Kinney 1970), were considered moderately stressed and analyzed as a separate group.

\section{Study design}

Patients were stratified for the presence of sepsis or stress and for age (under or over 65 years). They were randomized through the hospital pharmacy to receive a branched-chain amino acids enriched or a standard solution. Both solutions were delivered to the ward labeled "BCAA study solution" to ensure a double blind study design.

If renal failure progressed to a level necessitating proteinrestriction or dialysis and if fluid restriction prohibited the use of the study solution, patients were withdrawn. The studly was limited to seven days. Each day, starting on day $0,24 \mathrm{hr}$ urine was collected for nitrogen and 3-methylhistidine determination. Bistrian catabolic indices (Bistrian 1979), Elebute and Stoner sepsis scores (Elebute 1983) and nitrogen balances were calculated daily. Mortality was recorded as early-sepsis-related if death in overwhelming sepsis occurred within the 7 day study period, late-sepsis-related if death occurred under septic conditions after the study period or as not sepsis-related.

\section{Solutions}

Both amino acid - dextose mixtures contained equal amounts of amino acid nitrogen/L, derived in the standard solution from a balanced synthetic amino acid solution (Synthamin $14^{\circledR}$ ), and derived in the branched-chain amino acid enriched solution from a more concentrated balanced synthetic amino acid solution (Synthamin $17^{\circledR}$ ) and a $4 \%$ BCAA solution containing equimolar amounts of valine, isoleucine and leucine. The standard solution contained 15.6\% BCAA and 
the BCAA solution 50.2\% BCAA of total nitrogen (table 2.1). Each mixture contained $20 \%$ glucose. Both nutritional support solutions were composed according to the standards of today's practice, providing sufficient minerals, trace elements, vitamins and free fatty acids. Caloric intake was calculated to meet basal energy expenditure (Harris-Benedict) augmented with $10 \%$ specific dynamic action of food and a stress percentage as suggested by Kinney, ranging from $10-60 \%$ (Kinney 1970) (table 2.2) resulting in sufficient caloric intake to cover actual total energy expenditure (Van Lanschot 1986). Patients were not allowed any additional food. Blood and blood products were administered as required.

\section{Morbidity parameters}

Organ function was assessed using the scoring method as proposed by Stevens (Stevens 1983). The scoring method was adapted to fit local treatment policies, e.g. the use of ventilatory support would not always reflect the presence of respiratory insufficiency and scoring respiratory function was therefore adapted as summarized in table 2.3. Similar adjustments were made for scoring renal (creatinine clearance with each patient as his own control instead of plasma creatinine levels) and circulatory function (grouping of the Stevens scores to compensate for the use of dopamine to improve tissue perfusion, rather than to treat hypotension). In each organ system high scores represent organ function impairment; while low scores indicate a more normal function. Because of our interest in organ function per se rather than an overall morbidity score, our adaptation of the scoring system would not need further validation than performed by Stevens.

Organ function scores were assessed on days 0,4 and seven.

\section{Laboratory determinations}

Urinary 3-methylhistidine content was analyzed after hydrolysis on an LKB automated amino acid analyzer (LKB Biochrom Ltd, Cambridge, UK). Urinary nitrogen excretion was analyzed using the Kjeldahl method. Nitrogen balances were estimated by subtracting urinary nitrogen plus a correction factor for faecal and insensible losses from total nitrogen intake. Furthermore, a correction for accumulation or loss of urea was carried out, assuming the distribution volume for urea being $60 \%$ of body weight. Nitrogen in plasma and albumin was considered protein available for metabolic processing and was therefore accounted for in nitrogen balances. 


\section{Statistical considerations}

It was estimated that a $30 \%$ reduction of a -20 gram cumulative nitrogen balance in 1 week, with a standard deviation of 10 grams would be significant. To demonstrate such a result with alpha $=0.05$ and beta $=0.1$ we calculated that approximately 45 patients per study arm were required (Pocock 1983).

Results were evaluated using one way ANOVA's. Organ function scoring was evaluated using Chi-square tests.

\section{RESULTS}

\section{Patients}

One hundred and one patients were included in the study, with 61 of them requiring treatment in the intensive care unit. Forty nine patients received the BCAA solution, and 52 the standard solution. Both groups were comparable for age and sex, calculated basal energy expenditure values on day 0 , day 0 sepsis scores and catabolic indices (table 3.1). Primary diagnoses were reasonably equally distributed (table 3.2). Diagnoses listed under "other" included: tetanus, sepsis of unknown origin, respiratory insufficiency with pneumonia, prolonged paralytic ileus, etc. The subgroup of moderately stressed patients (stress factor ranging between 20 and $50 \%$ ) was the largest in size, and more homogeneous, because the more severely stressed group contained extremely ill patients, some of whom underwent one or more operations. Study groups within this moderately stressed population were also comparable with respect to all of the above criteria (tables 3.1 and 3.2). Three patients were withdrawns from the study because of progressive renal failure necessitating a fluid restriction and adaptation of the administered parenteral nutrition.

\section{Solutions}

Patients in both study groups received a similar nutritional support regimen, except for the BCAA content: 0.09 gram BCAA nitrogen $(0.56$ gram BCAA protein) vs. 0.03 gram BCAA nitrogen ( 0.18 gram BCAA protein) per $\mathrm{kg}$ body weight (table 3.3).

\section{Catabolic indices}

Mean catabolic index scores in both groups decreased during the study without statistically significant difference between groups (fig. 3.1). 


\begin{tabular}{|c|c|c|c|c|}
\hline & \multicolumn{2}{|l|}{$\begin{array}{l}\text { Total group } \\
(n=101)\end{array}$} & \multicolumn{2}{|c|}{$\begin{array}{l}\text { Moderately stressed groun } \\
(n=73)\end{array}$} \\
\hline & $\begin{array}{l}\text { BCAA } \\
(n=49) \\
\bar{x} \pm \operatorname{sem}\end{array}$ & $\begin{array}{l}\text { Standard } \\
(\mathrm{n}=52) \\
\bar{x} \pm \operatorname{sem}\end{array}$ & $\begin{array}{l}\mathrm{BCAA} \\
(n=35) \\
\bar{x} \pm \text { sem }\end{array}$ & $\begin{array}{l}\text { Standard } \\
(n=38) \\
\bar{x} \pm \text { sem }\end{array}$ \\
\hline \multirow[t]{2}{*}{ Sex } & 21 & 25 & 14 & 19 \\
\hline & 28 & 27 & 21 & 19 \\
\hline Age (years) & $56 \pm 2$ & $58 \pm 2$ & $59 \pm 2$ & $57 \pm 3$ \\
\hline $\mathrm{BEE}$ (Kcal/day) & $1440 \pm 40$ & $1390 \pm 30$ & $1400 \pm 41$ & $1390 \pm 31$ \\
\hline Stress \%: $0-20 \%$ & 5 & 4 & & \\
\hline $20-50 \%$ & 35 & 38 & & \\
\hline$\geq 50 \%$ & 9 & 10 & & \\
\hline Elebute + Stoner & & & & \\
\hline $\begin{array}{l}\text { sepsis score } \\
\text { (day } 0)\end{array}$ & $11.1 \pm 0.8$ & $10.9 \pm 0.9$ & $11.0 \pm 0.9$ & $10.0 \pm 0.8$ \\
\hline $\begin{array}{l}\text { Bistrian score } \\
\text { (day } 0 \text { ) }\end{array}$ & $10.3 \pm 1.3$ & $9.8 \pm 1.0$ & $8.1 \pm 0.9$ & $9.8 \pm 0.9$ \\
\hline
\end{tabular}

BEE: Basal Energy Expenditure

\section{Sepsis scores}

Mean sepsis scores remained in the same range in the branched-chain group and tended to decrease in the standard group, but without statistically significant difference between groups (fig. 3.2).

\section{Morbidity scores}

Results of organ function scoring are depicted in figure 3.3. With the frequency of each score being expressed as percentage of the total number of patients per study group, improvement of organ function was observed within each organ system, without difference between study groups. For statistical considerations changes of each organ function score were pooled per study group as increasing, 
Table 3.2 Diagnoses.

\section{Total group \\ $(n=101)$}

BCAA Standard

Moderately stressed group $(n=73)$

BCAA Standard

Perforated viscera,

9

15

7

\section{1}

anastomotic leakage, etc.

\section{Pancreatitis}

Enterocolitis

$\begin{array}{rr}8 & 11 \\ 7 & 6\end{array}$

(radiation, Crohn's disease,

ulcerative colitis, ischemia)

$\begin{array}{lrrrr}\text { Intra-abdominal abscess } & 9 & 6 & 7 & 5 \\ \text { Multiple injuries } & 4 & 2 & 2 & 1 \\ \text { Ruptured aortic aneurysm } & 3 & 2 & 2 & 1 \\ \text { Other } & 9 & 10 & 6 & 7 \\ \text { Total } & 49 & 52 & 35 & 38\end{array}$

Table 3.3 TPN Characteristics.

\begin{tabular}{|c|c|c|c|c|c|}
\hline & \multicolumn{2}{|l|}{$\begin{array}{l}\text { Total group } \\
(n=101)\end{array}$} & \multicolumn{3}{|c|}{$\begin{array}{l}\text { Moderately stressed group } \\
(\mathrm{n}=73)\end{array}$} \\
\hline & $\begin{array}{l}\mathrm{BCAA} \\
\bar{x} \pm \mathrm{SD}\end{array}$ & $\begin{array}{l}\text { Standard } \\
\bar{x} \pm S D\end{array}$ & $\begin{array}{l}\mathrm{BCAA} \\
\overrightarrow{\mathrm{x}} \pm \mathrm{SD}\end{array}$ & $\begin{array}{l}\text { Standard } \\
\overline{\mathrm{x}} \pm \mathrm{SD}\end{array}$ & \\
\hline NPE Cal/N & $205 \pm 33$ & $214 \pm 28$ & $202 \pm 24$ & $214 \pm 28$ & $\mathrm{Kcal} / \mathbb{E N}$ \\
\hline NPE Cal/kg & $33 \pm 11$ & $34 \pm 9$ & $34 \pm 12$ & $34 \pm 9$ & $\mathrm{Kcal} / \mathrm{kg}$ \\
\hline $\mathrm{N} / \mathrm{kg}$ & $0.17 \pm 0.05$ & $0.17 \pm 0.04$ & $0.17 \pm 0.04$ & $0.17 \pm 0.0$ & $4 \mathrm{~g} / \mathrm{kg}$ \\
\hline BCAA N/kg & 0.09 & 0.03 & 0.09 & 0.03 & $\mathrm{~g} / \mathrm{kg}$ \\
\hline Percentage fat & $13 \pm 9$ & $16 \pm 8$ & $13 \pm 9$ & $16 \pm 8$ & $\%$ \\
\hline Percentage BEE & $148 \pm 35$ & $157 \pm 4$ & $152 \pm 36$ & $155 \pm 3$ & $\%$ \\
\hline
\end{tabular}

(NPE: non protein energy; $\mathrm{N}$ : nitrogen; BEE: basal energy expenditure) 
BISTRIAN SCORES

$\bar{x} \pm s e m$

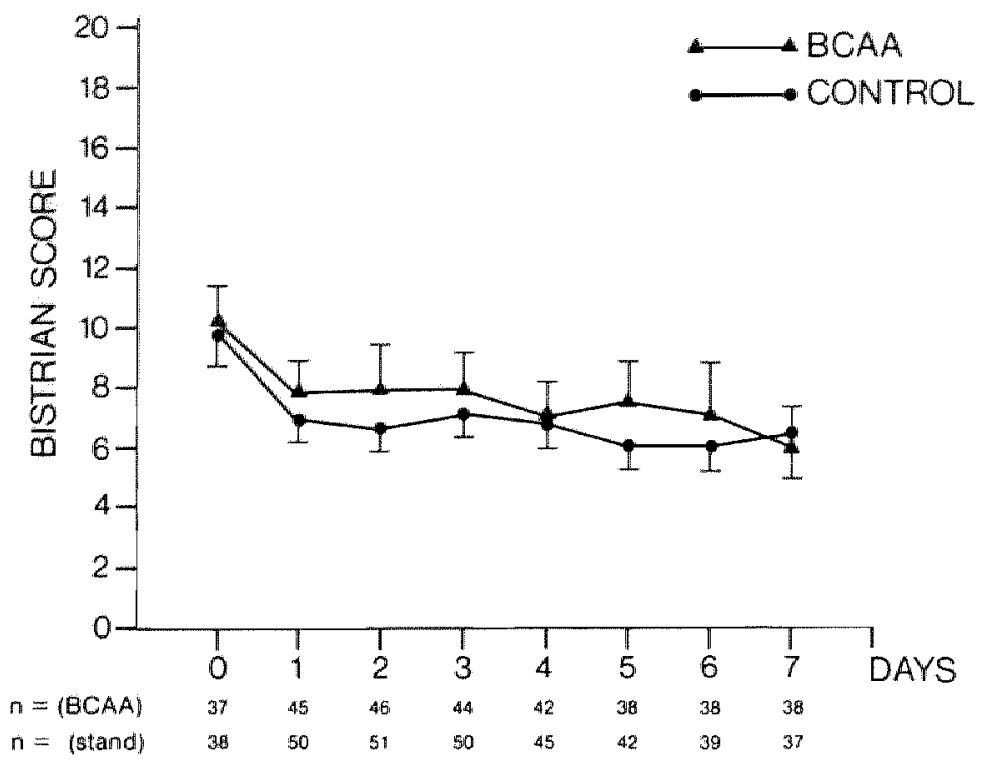

Figure 3.1 Catabolic indices calculated according to Bistrian's method

\section{ELEBUTE AND STONER SEPSIS SCORE}

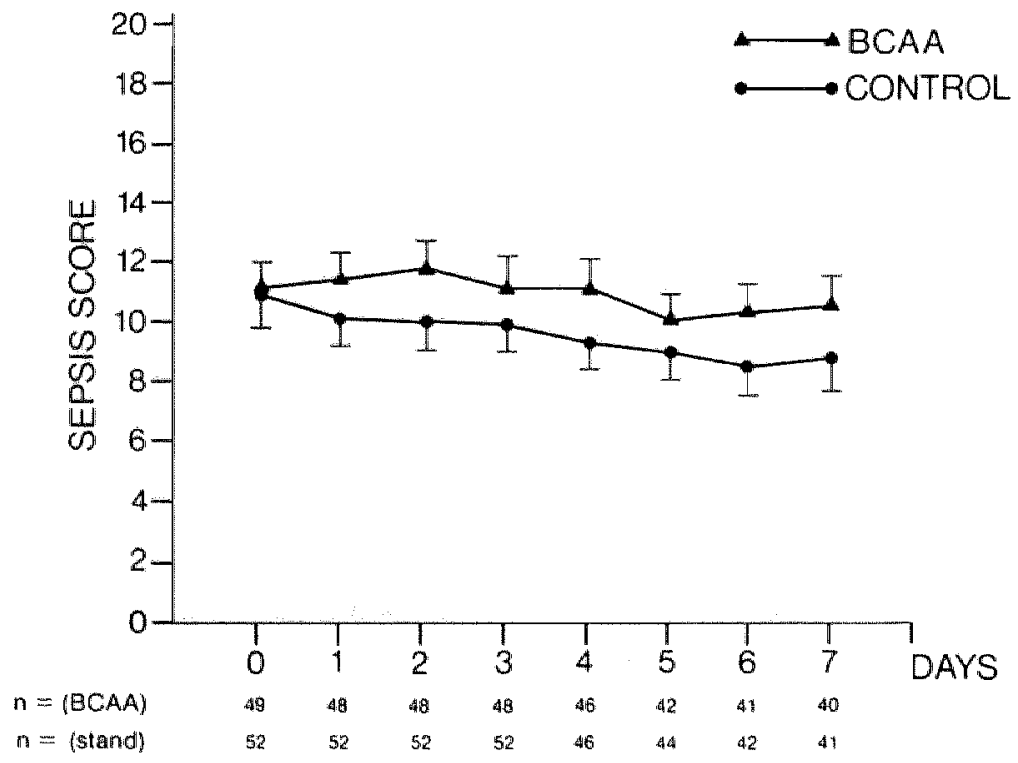

Figure 3.2 Sepsis scores, calculated as described by Elebute and Stoner 
stable or decreasing in the 0-4 day and 4-7 day periods and subsequently evaluated by a Chi-square test. No significant difference within any organ system was observed between groups.

\section{Biochemical data}

Fig. 3.4 displays mean daily nitrogen balances corrected for urea accumulation per study group. The number of available analyses is displayed, as in all other figures. Plasma protein derived nitrogen intake was not different between study groups. Although in the total study population days 4 and 7 show a significantly $(p<0.05$, ANOVA) less negative nitrogen balance in the BCAA group, as compared to the standard group, cumulative 7-day nitrogen balances are not significantly different between groups (table 3.4). Nitrogen balances in the moderately stressed patient group were consistently, albeit not significantly less negative in the BCAA group (fig. 3.5). Cumulative nitrogen balances were less negative in the BCAA group but significance was not reached $(\mathrm{p}=0.06)$ (table 3.4). Mean daily urinary 3-methylhistidine excretion diminished significantly during the study period, but no significant differences between groups are noted (fig. 3.6).

\section{Mortality}

Overall mortality was not different between groups (table 3.5), nor was late or early sepsis related mortality, or non sepsis related mortality. Mortality was not different between groups in the moderately stressed study population either.

\section{DISCUSSION}

The observation that nitrogen losses during sepsis and trauma can be diminished, but not reversed, with nutritional regimens of conventional composition stimulated the development of special amino acid compositions. Specifically enrichment with branched-chain amino acids may correct decreased plasma BCAA levels reported during sepsis and trauma, and consequently improve the precursor pattern for protein synthesis (Freund 1980, Clowes 1984). BCAA may further furnish fuel and promote protein synthesis (Buse 1975).

Only two prospective randomized trials have been published investigating the effect of BCAA enrichment of TPN solutions in sufficiently large study populations (Cerra 1987, Okada 1988). In one trial patients with pancreatitis and organ failure were excluded (Cerra 1987). An improvement of nitrogen balance was found on only one (4th) day of the seven day study period. In the other trial patients suffering a uniform trauma were studied in a multicentre study design (Okada 1988). Patients were dropped from the study once the development of 


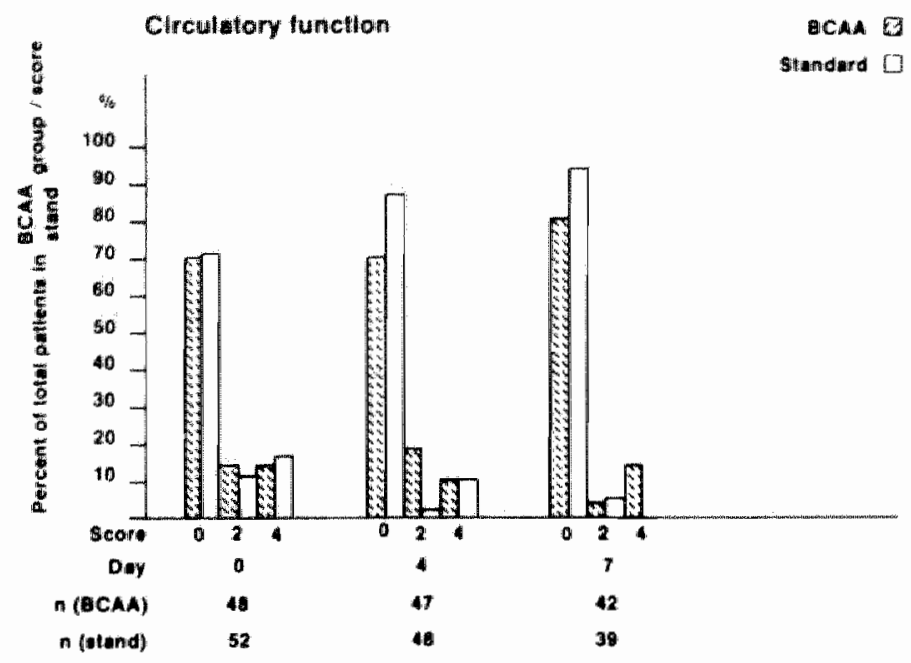

Figure 3.3a The number of low scores for circulatory function increase across days. Although high scores seem to diminish more in the standard group, a convincing advantage for the standard solution is not seen.

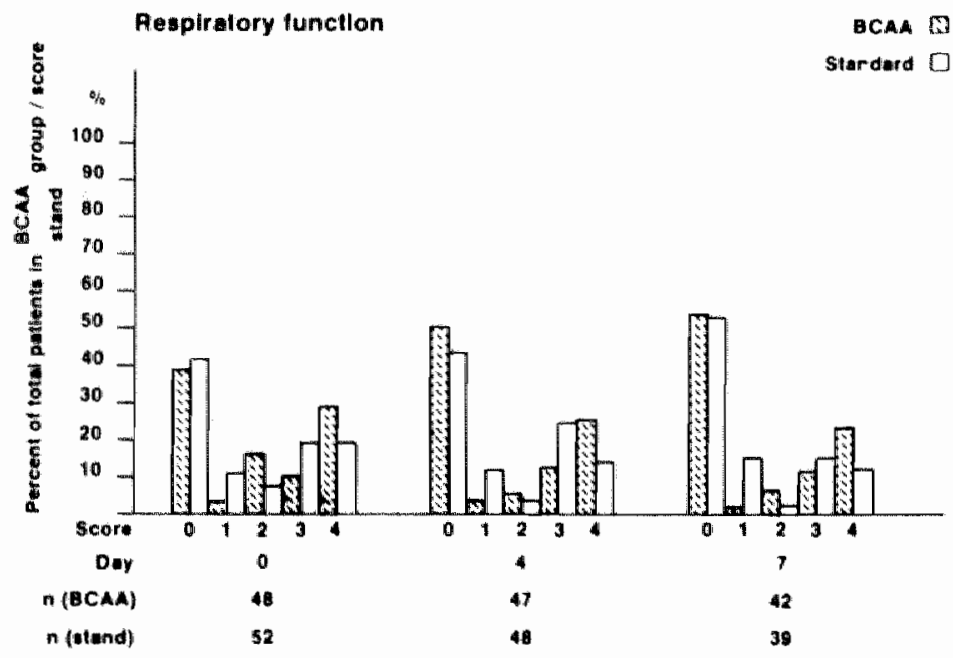

Figure 3.3b Respiratory 0 scores increase across days in both groups, while higher scores decrease. No obvious difference between study groups is noticeable. 


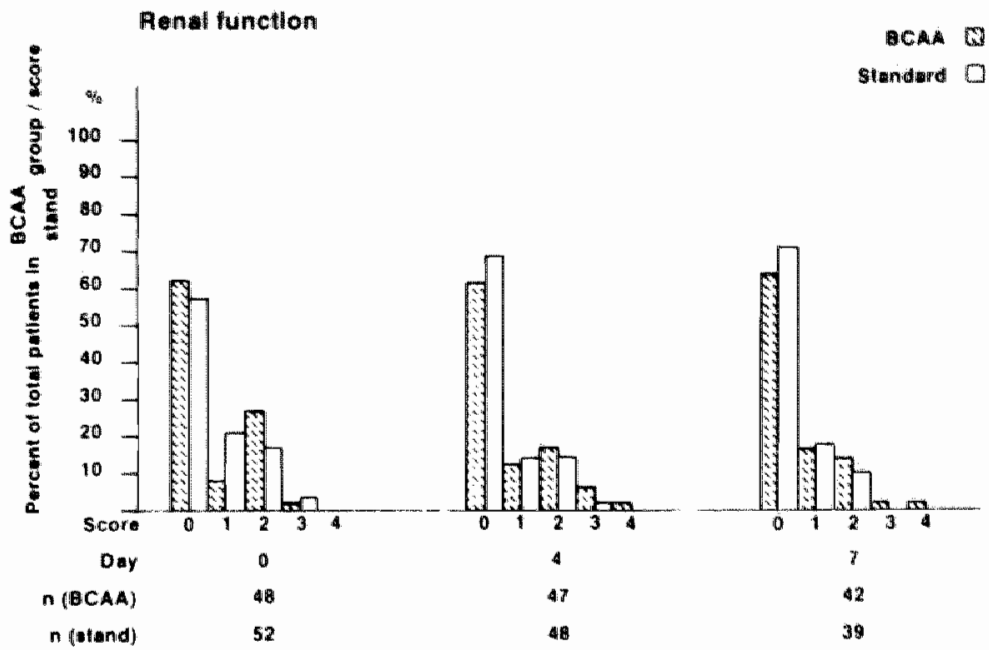

Figure 3.3c Frequency of scores distribution of renal function does not seem to change across days in either solution.

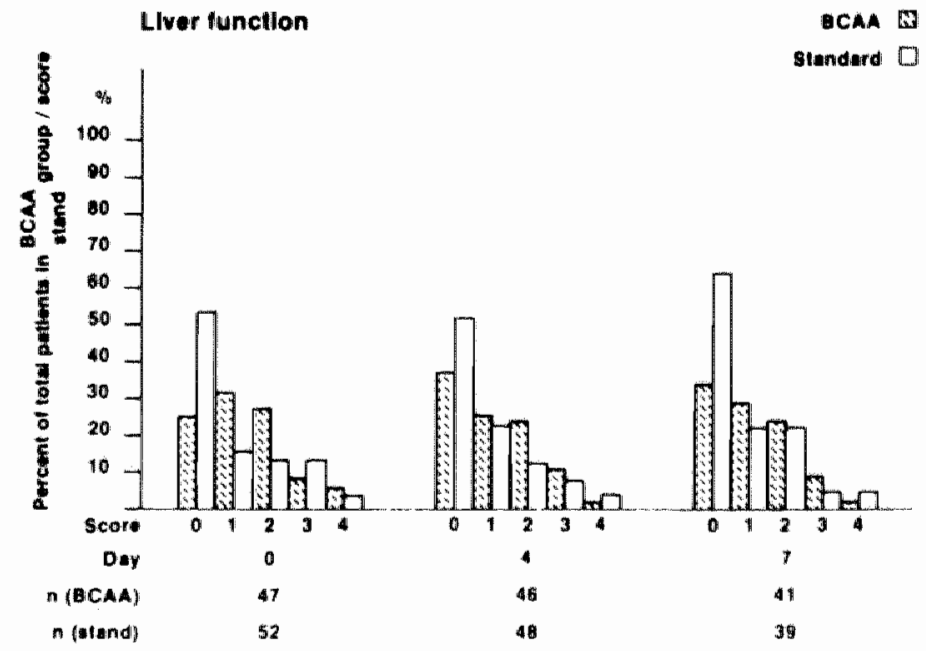

Figure 3.3d Distribution of scores for hyperbilirubinemia were not equal in the study groups on day 0 , with patients in the standard group showing score 0 significantly more frequently. Also within this organ system a tendency towards improved organ function is noticeable, without obvious advantage for either solution. 


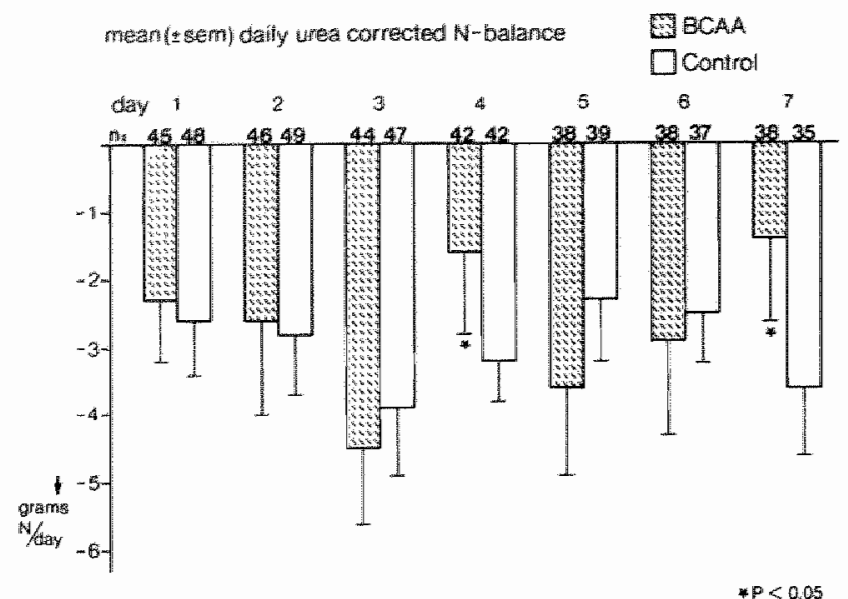

Figure 3.4 Mean daily mitrogen balances per study group. Nitrogen balances are corrected for urea accumulation or loss, excessive stool, stoma or fistula output, and administration of plasma proteins.

Table 3.4. Cumulative 7 day $N$-balance $(\bar{x} \pm$ sem $)$.

\section{Total group}

$\begin{array}{llll}\text { BCAA } & (\mathrm{n}=37) & -19.1 \pm 7.3(\mathrm{~g}) & \\ \text { Standard } & (\mathrm{n}=34) & -20.8 \pm 4.5(\mathrm{~g}) & \text { n.s. }\end{array}$

Moderately stressed group

$\begin{array}{llll}\text { BCAA } & (\mathrm{n}=28) & -8.5 \pm 5.2 & \mathrm{p}=0.06 \\ \text { Standard } & (\mathrm{n}=26) & -23.0 \pm 5.5 & \end{array}$

Table 3.5. Mortality.

Total group

BCAA Standard

Early sepsis related

Late sepsis related

Not sepsis related

$\begin{array}{lc}4(8.2 \%) & 2(3.8 \%) \\ 8(16.3 \%) & 10(19.2 \%) \\ 5(10.2 \%) & 4(7.7 \%)\end{array}$

$17(3.4 .7 \%) \quad 16(30.7 \%)$
Moderately stressed group

BCAA Standard

$2(5.7 \%) \quad 2(5.3 \%)$

$7(20.0 \%) \quad 3(7.9 \%)$

$5(14.3 \%) \quad 3(7.9 \%)$

$14(40.0 \%) \quad 8(21.1 \%)$ 


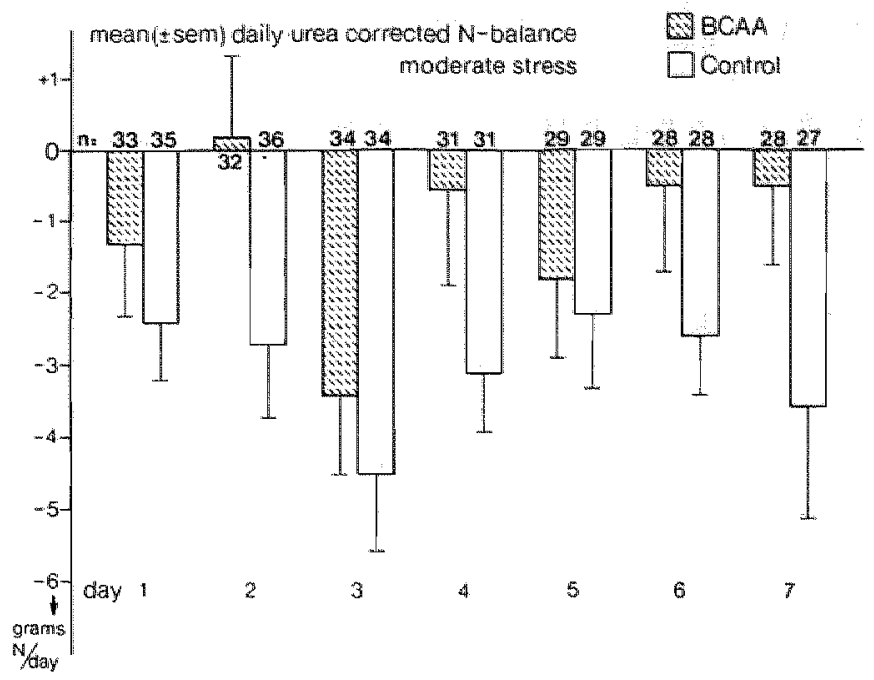

Figure 3.5 Mean daily nitrogen balances per study group in the moderately stressed patient population.

Mean (t sem) daily urinary 3-MH excretion

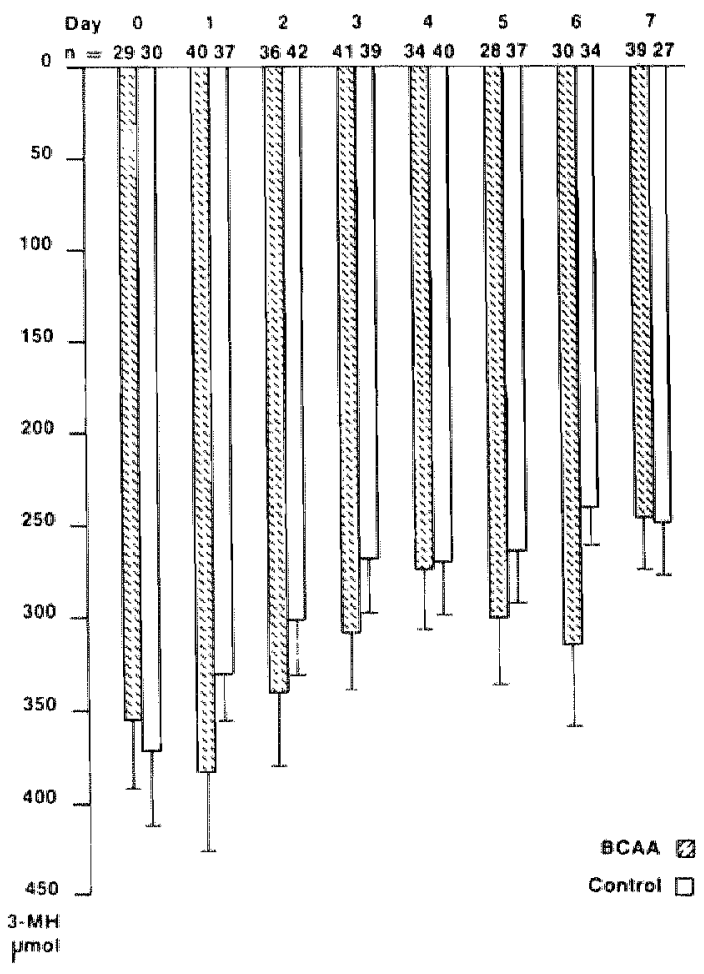

Figure 3.6 Mean daily urinary 3-methylhistidine excretion per study group. 
organ failure became apparent. As in the previous study a modest though not statistically significant improvement of nitrogen balance was observed in one of the trial subgroups. In these studies the clinical state of the patients was not detailed before, during or after the study period. This was not done either in the other smaller studies (Cerra 1982, Nuwer 1983, Cerra 1984, Bower 1986, Jaing 1988).

We studied the nitrogen balance and clinical benefit in an unselected study population suffering from severe illness or sepsis. The assessment of clinical performance of each individual organ system must be the most accurate and independently obtainable measure to study clinical efficacy. To detect differences larger patient groups were necessary which were comparable in every respect. We therefore stratified for age, sepsis and stress and ensured that patients received an amount of calories equaling their estimated actual energy expenditure. All patients received fat, no patient received more than 35 carbohydrate calories $/ \mathrm{kg} / 24 \mathrm{~h}$. Patients received on average $1.1 \mathrm{~g}$ of AA/ $\mathrm{kg} / 24 \mathrm{~h}$ and $0.56 \mathrm{~g}$ of BCAA/kg/24 h in the enriched group which is in the range where an eventual benefit on nitrogen balance should have manifested itself (Cerra 1983). If patients were considered more severely stressed they received proportionally more calories and nitrogen, including BCAA. Both groups (controls and BCAA enriched) proved to be comparable at day 0 with regard to disease, age, sex, sepsis-scores, Bistrian score and organ function score. Only hyperbilirubinemia was encountered more often in the BCAA enriched group.

We are aware that the methods used to estimate nitrogen balances include crude approximations but few studies have made an attempt to correct for total body urea accumulation or the metabolic fate of exogenous protein (Lundholm 1986).

The study failed to confirm a clear benefit of BCAA enrichment on nitrogen balance in the total patient population. When the subgroup that was considered moderately stressed on day 0 was selected $(n=73)$ cumulative nitrogen balance improved in the BCAA enriched group although this improvement failed to reach significance $(p=0.06)$. In this group nitrogen balance was better on any single day (day 1-7) although on no occasion significance was reached.

BCAA enrichment may improve nitrogen balance in moderately stressed patients but differences in clinical outcome (mortality, organ function, catabolic indices and sepsis score) were not observed.

The results of this trial may be explained by the fact that clinical outcome in septic or traumatized patients is much more dependent on the success of primary treatment (drainage of abscesses, debridement of necrotic tissue, stabilization of fractures etc.) than on supportive care. The acute effects of nutritional support or the effects of a modification of nutritional support under such conditions must be 
limited. We conclude that BCAA enriched TPN solutions, commonly marketed as "trauma solutions" possibly achieve a modest improvement in nitrogen balance in moderately stressed patients but do not induce a clear clinical benefit. 


\section{REFERENCES}

Adibi $\$ A$, Peterson $\mathbb{J}$, Krysik $B$ A. Modulation of leucine transaminase activity by dietary means. Am J Physiol 228:432-435,1975.

Bistrian BR. A simple technique to estimate severity of stress. Surg Gynecol Obstet 148:675$678,1979$.

Bower RH, Muggia-Sullam M, Vallgren S et al. Branched-chain amino acid-enriched solutions in the septic patient. A randomized, prospective trial. Ann Surg 203:13-20,1986.

Buse MB, Reid M. Leucine, a possible regulator of protein turnover in muscle. J Clin Invest $56: 1250-1261,1975$.

Cerra FB, Upson D, Angelico R et al. Branched-chains support postoperative protein synthesis. Surgery 92:192-199,1982.

Cerra FB, Mazuski J, Teasley K et al. Nitrogen retention in critically ill patients is proportional to the branched-chain amino acid load. Crit Care Med 11:775-778,1983.

Cerra FB, Mazuski JE, Chute E et al. Branched-chain metabolic support. A prospective, randomized, double-blind trial in surgical stress. Ann Surg 199:286-291,1984.

Cerra F, Blackburn G, Hirsch J, Mullen K, Luther W. The effect of stress level, amino acid formula, and nitrogen dose on nitrogen retention in traumatic and septic stress. Ann Surg $205: 282-287,1987$.

Clowes GHA, O'Donnell TF, Ryan NT, Blackburn GL. Energy metabolism in sepsis: treatment based on different patterns in shock and high output state. Ann Surg 179: 684-696,1974.

Clowes GHA, McDermott WV, Williams LF, Loda M, Menzoian O, Pearl R. Amino acid clearance and prognosis in surgical patients with cirthosis. Surgery 96:675-684,1984.

Elebute EA, Stoner HB. The grading of sepsis. Br J Surg 70:29-31,1983.

Freund $H$, Yoshimura N, Fischer JE. The effect of branched-chain amino acids and hypertonic glucose infusions on postinjury catabolism in the rat. Surgery 87:401-408,1980.

Jaing $Z$, Zhang $F$, Zhu $Y$, He $G_{n}$ Fei L, Tseng H, Sugarbaker S, Wilmore DW. Evaluation of parenteral nutrition in the postoperative patient. Surg Gynecol Obstet 166:115-120,1988.

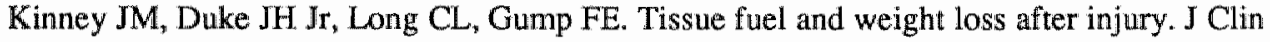
Pathol 23 (suppl 4):65,1970.

Lanschot van JJB, Feenstra BWA, Vermey CG, Bruining HA. Calculation vs measurement total energy expenditure. Crit Care Med 14:981-985,1986.

Lundholm K, Bennegard K, Wickstróm I, Lindmark L. Is it possible to evaluate the efficacy of amino acid solutions after major surgical procedures or accidental injuries? Evaluation in a randomized and prospective study. JPEN 10:29-33,1986.

Mizock B. Branched-chain amino acids in sepsis and hepatic failure. Arch Intem Med. 145:1.284-1288, 1985.

Nuwer N, Cerra FB, Shronts EP, Lysne J, Teasley KM, Konstantinides FN. Does modified. amino acid total parenteral nutrition alter immune response in high level surgical stress. JPEN $7: 521-524,1983$.

O'Donnell TF, Clowes GHA, Blackburn GL et al. Proteolysis associated with a deficit of peripheral energy fuel sub strate in septic man. Ann Surg 80:192-200,1976.

Okada A, Mori S, Totsuka M, Okamoto K, Usui S, Fujita H, Irakura T, Mizote H. Branchedchain amino acids metabolic support in surgical patients: A randomized, controlled trial in patients with subtotal or total gastrectomy in 16 Japanese institutions. JPEN 12:332337,1988 . 
Pocock SJ. Clinical trials, a practical approach. Chichester, New York, Brisbane etc.: John Wiley \& Sons; 123-141,1983.

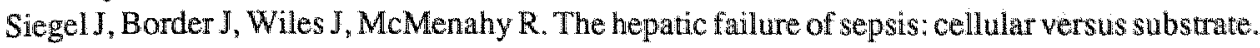
Surgery 86:409-422,1979.

Stevens LE. Gauging the severity of surgical sepsis. Arch Surg 118:1190-1192,1983. 



\section{A prospective randomized double blind trial of branched-chain amino acid enriched versus standard parenteral nutrition solutions in traumatized and septic patients}

\section{SUMMARY}

Enlarging the proportion of branched-chain amino acids (BCAA) in total parenteral nutrition (TPN) solutions of a balanced amino acid composition has been reported to result in improved nitrogen balance, preservation of plasma protein levels and improved immune function. However, only few large clinical studies have been performed, yielding conflicting results. We therefore studied in a prospective randomized double blind trial the effects of BCAA-enrichment of an otherwise isonitrogenous and isocaloric TPN solution on plasma protein levels in 101 traumatized and septic patients.

TPN derived nitrogen intake was similar in both study groups. Nitrogen balances in the BCAA group $(n=49)$ were not different from those in the standard group $(n=52)$. Plasma total protein levels increased significantly in the standard group resulting in a significant difference between study groups on day 7 . Pre-albumin levels increased significantly in the BCAA-group and in the standard group. The number of neutrophils (bands) was significantly lower in the standard group compared to the BCAA group on day 7 . Lymphocytes increased significantly in the standard group as did the number of thrombocytes resulting in a significant difference between study groups on day 7 .

We conclude that BCAA enrichment of standard TPN solutions does not result in a more efficient nitrogen metabolism in septic or traumatized patients. 


\section{INTRODUCTION}

The enrichment with branched-chain amino acids (BCAA) of total parenteral nutrition (TPN) solutions with a balanced amino acid composition has been advocated over the last ten years in patients with metabolic stress, sepsis and trauma (Kem 1982, Cerra 1983, Nuwer 1983, Bonau 1984, Bower 1986). Under these circumstances metabolism is characterized by an increased proteolysis and protein synthesis leading to a net protein breakdown and progressively negative nitrogen balance (O'Donnel 1976).

The fact that during sepsis and trauma nutritional support of conventional composition may diminish nitrogen losses, but not achieve net nitrogen retention has stimulated the development of nutritional support regimens with special amino acid composition. Specifically enrichment with branched-chain amino acids may correct the low plasma $\mathrm{BCAA}$ levels reported during sepsis and trauma, thereby improving the plasma amino acid precursor pattern for protein synthesis (Freund 1978, Freund 1979, Nuwer 1983, Bonau 1984, Freysz 1989). Improved immune function in patients receiving BCAA enriched TPN solutions has been suggested on the basis of increasing absolute lymphocyte counts and normalization of skin test reactivity (Bonau 1984).

We therefore studied in a prospective randomized double blind trial effects of BCAA-enrichment of an otherwise isonitrogenous and isocaloric TPN solution on plasma protein levels in traumatized and septic patients.

The study was reviewed and approved by the Human Studies Committee of the University Hospital Maastricht.

\section{PATIENTS AND METHODS}

\section{Patients}

Both septic and traumatized patients were eligible to enter the study. Sepsis was considered present if patients suffered from a combination of spiking temperatures, leucocytosis and had a septic focus. In most cases a bacteremia could be documented. Traumatic stress was considered present if patients had suffered a multi-trauma, a ruptured abdominal aortic aneurysm, or acute non-septic fulminant pancreatitis. 


\section{Study design}

Patients were stratified for the presence of sepsis or stress, age under or over 65 years, and site of the primary septic focus (abdominal us pulmonary) before being randomized through the hospital pharnacy to receive a BCAA-enriched or a standard TPN solution. Both solutions were delivered to the ward labeled 'BCAA-study solution' to ensure the double blind design.

Nutritional support was calculated to contain as non-protein energy the equivalent of basal energy expenditure, calculated through the Harris Benedict equation, augmented with $10 \%$ specific dynamic activity of food and a stress percentage as described by Kinney et al (Kinney 1970).

The study lasted 7 days. A patient was taken off the study if during the study renal failure progressed to a level necessitating protein restriction or dialysis, or if cardiac failure prohibited the use of the study solution.

\section{Solutions}

Both solutions contained 800 Glucose $\mathrm{Kcal} / \mathrm{l}$ and 5 gram amino acid nitrogen $/ 1$. BCAA content was $15.6 \%$ of total amino acids in the standard solution, and 50.2 $\%$ in the branched-chain amino acid enriched solution, in equimolar amounts in both solutions. Intravenous fat emulsions were administered at least twice per week, and daily if energy needs exceeded $2000 \mathrm{Kcal}$ per day. Trace elements, vitamins and electrolytes were provided in sufficient quantities.

\section{Laboratory determinations}

Nitrogen balances were estimated by subtracting urinary nitrogen plus a correction factor for fecal and insensible losses from totall nitrogen intake. In addition, a correction for the accumulation of urea was performed, assuming the distribution volume of urea being $60 \%$ of body weight.

Levels of plasma proteins were determined according to standard laboratory techniques.

\section{Statistical considerations}

A $30 \%$ reduction of a -20 gram cumulative nitrogen balance over 7 days with a standard deviation of 10 grams was considered significant. It was calculated that approximately 45 patients per study arm would be required to demonstrate this difference with alpha $=0.05$ and beta $=0.1$. 


\section{Patients}

One hundred and one patients were included in the study, 49 receiving the BCAA-solution and 52 the standard amino acid solution. In addition, the diagnoses were comparable for both groups (table 4.1). Both groups were comparable for age and sex, and showed similar stress score distributions on day 0 (table 4.2).

Table 4.1 Diagnoses.

\begin{tabular}{lcc}
\hline & BCAA & Standard \\
\hline Perforated viscera, anastomotic leakage, etc. & 9 & 15 \\
Pancreatitis & 8 & 11 \\
Enterocolitis & 7 & 6 \\
(radiation, Crohn's disease, ulcerative colitis, ischemia) & & \\
Intra-abdominal abscess & 9 & 6 \\
Multiple injuries & 4 & 2 \\
Ruptured aortic aneurysm & 3 & 2 \\
Other & 9 & 10 \\
Total & & 52 \\
\hline
\end{tabular}

Table 4.2. Study population $(n=101)$.

\begin{tabular}{llll}
\hline & $\begin{array}{l}\text { BCAA } \\
(\mathrm{n}=49)\end{array}$ & $\begin{array}{l}\text { Standard } \\
(\mathrm{n}=52)\end{array}$ \\
\hline Sex & female & 21 & 25 \\
& male & 28 & 27 \\
Age (years) & $56 \pm 2$ & $58 \pm 2$ \\
BEE (Kcal/day) & $1440 \pm 40$ & $1390 \pm 30$ \\
Stress $\%: \quad 0-20 \%$ & 5 & 4 \\
$20-50 \%$ & 35 & 38 \\
$250 \%$ & 9 & 10 \\
\hline
\end{tabular}

Mean \pm sem 


\section{Solutions}

The actually administered amounts of total non-protein energy, amino acid nitrogen and energy derived from fat were comparable for both groups (table 4.3). The essential amino acid content of both solutions is summarized in table 2.1. The BCAA addition is corrected in both the essential and the non-essential amino acid fraction of the standard solution.

Table 4.3. TPN Characteristics $(n=101)$.

\begin{tabular}{lll}
\hline & $\begin{array}{l}\text { BCAA } \\
(\mathrm{n}=49)\end{array}$ & $\begin{array}{l}\text { Standard } \\
(\mathrm{n}=52)\end{array}$ \\
\hline NPE Cal/N & $205 \pm 33$ & $214 \pm 28$ \\
NPE Cal/kg & $33 \pm 11$ & $34 \pm 9$ \\
N/kg & $0.17 \pm 0.05$ & $0.17 \pm 0.04$ \\
BCAA N/kg & 0.09 & 0.03 \\
Percentage fat & $13 \pm 9$ & $16 \pm 8$ \\
Percentage BEE & $148 \pm 35$ & $157 \pm 4$ \\
\hline
\end{tabular}

Mean \pm sem

\section{Laboratory data}

Parameters of nitrogen balances in both treatment groups are listed in table 4.4. One way ANOVA's indicated that TPN derived nitrogen intake was similar in both study groups. Nitrogen intake from other sources (e.g. plasma, albumin) was not different between groups.

Urinary nitrogen excretion, nitrogen losses from other sources (e.g. stoma output, drain losses) were not different between groups or across days. Daily nitrogen balances were negative, and not different between the study groups or across days. Cumulative nitrogen balances $(\overline{\mathrm{x}} \pm \mathrm{sem})$ were not different either: BCAA group $-20.9 \pm 3.3 \mathrm{~g}$, standard group $-20.2 \pm 2.4 \mathrm{~g}$.

To further investigate the capability of the BCAA to improve nitrogen retention regression lines were calculated between administered TPN derived nitrogen, and excreted urinary nitrogen or nitrogen balances per patient on all study days. If BCAA enrichment would result in a more efficient use of nitrogen the relationship between these parameters would be different between the study groups. The 


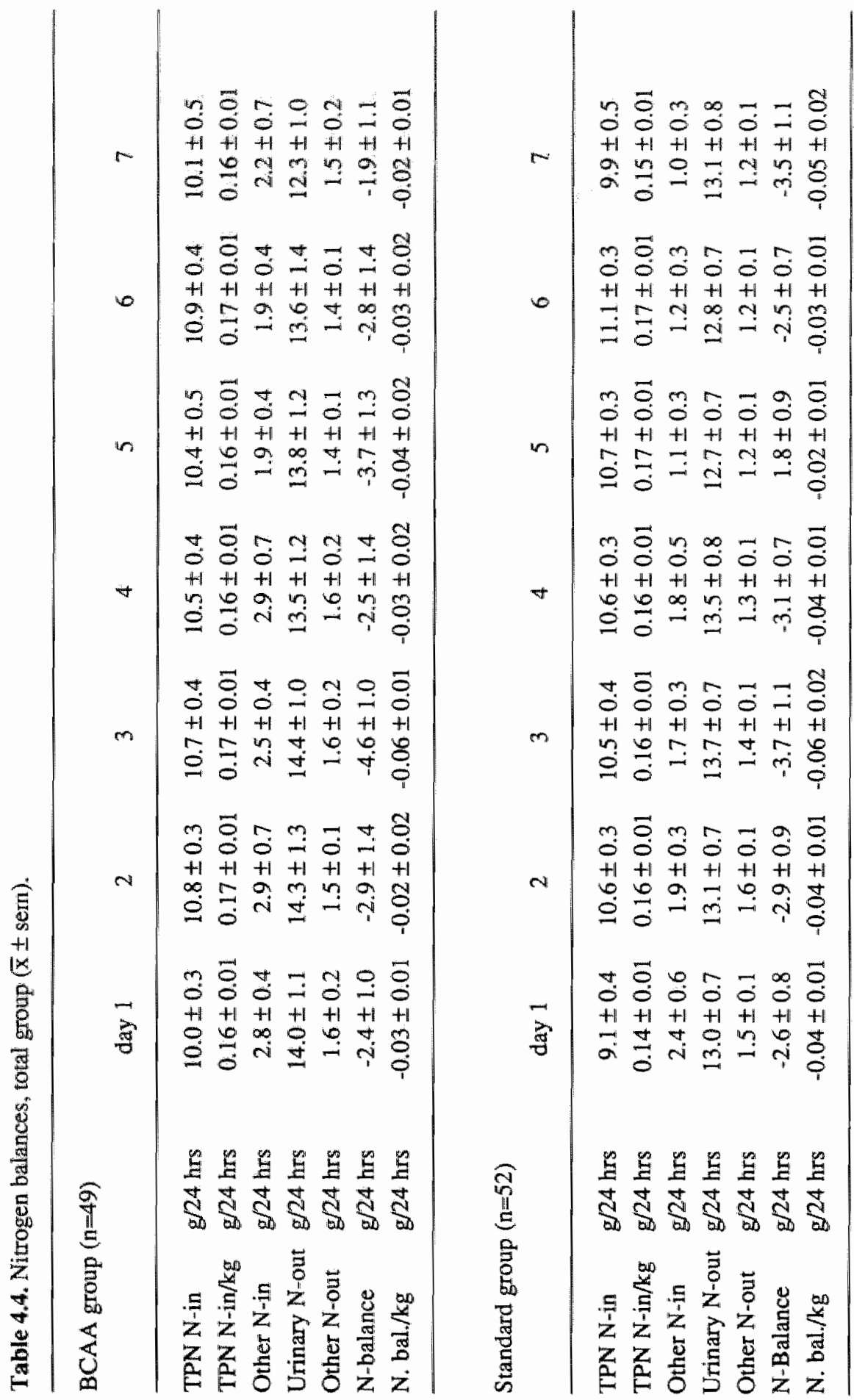




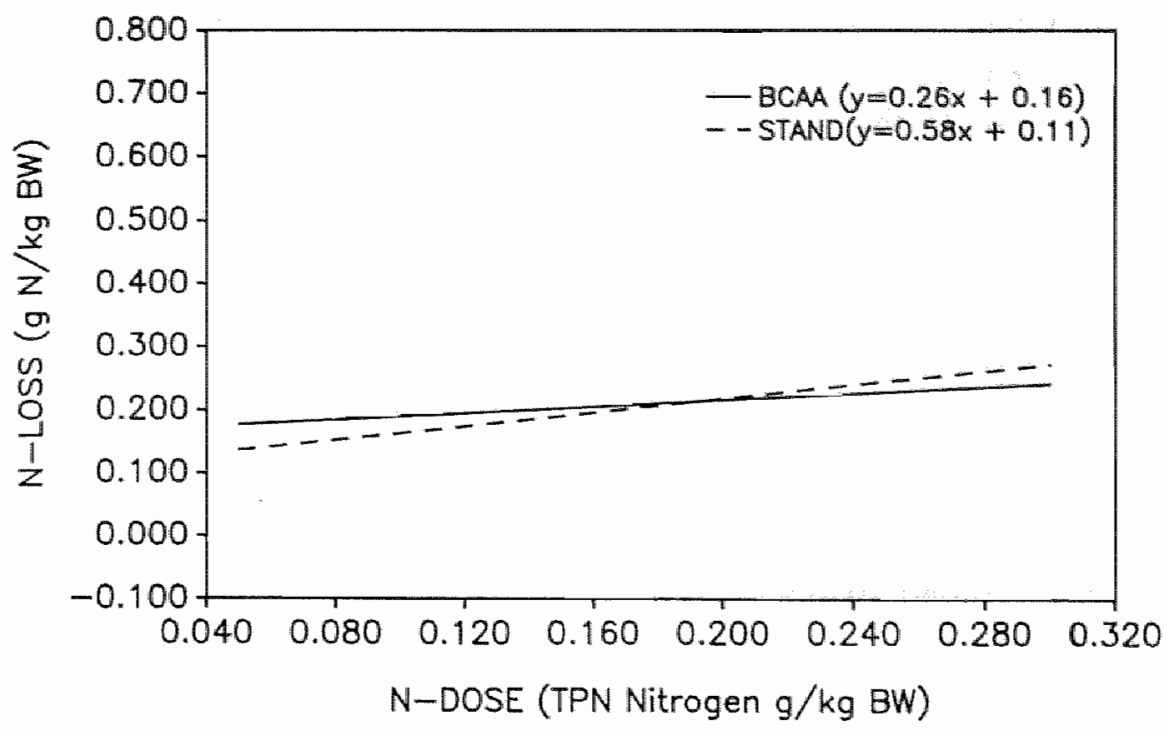

Figure 4.1 Regression lines between TPN derived nitrogen ( $\mathrm{g} / \mathrm{kg} \mathrm{BW}$ ) and urinary nitrogen loss ( $\mathrm{g} / \mathrm{kg} \mathrm{BW}$ ) on any day in the BCAA group $\left(\mathrm{n}=373, \mathrm{r}=0.122, \mathrm{r}^{2}=0.048\right)$ and the standard group $\left(n=364 ; r=0.370 ; r^{2}=0.137\right)$. The slopes of both lines are not different, suggesting that the administration of BCAA nitrogen does not result in decreased nitrogen excretion.

administration of BCAA enriched TPN solutions, however, did not result in an improved nitrogen retention as compared to the standard formulated amino acid solution (fig. 4.1 and 4.2).

Plasma levels of pre-albumin increased significantly across days in both study groups. Total protein levels increased significantly in the standard group (table 4.5). Total protein was significantly higher in the standard group compared to the BCAA group on day 7.

Blood cell counts indicated a significant rise of the total number of lymphocytes across days (table 4.6). Thrombocyte counts on day 0 were significantly lower compared to values on day 7 in the standard group. The bands (neutrophils) were significantly lower on day 7 in the standard group, while thrombocytes were significantly higher on the same day in this group if compared to the BCAA group. 


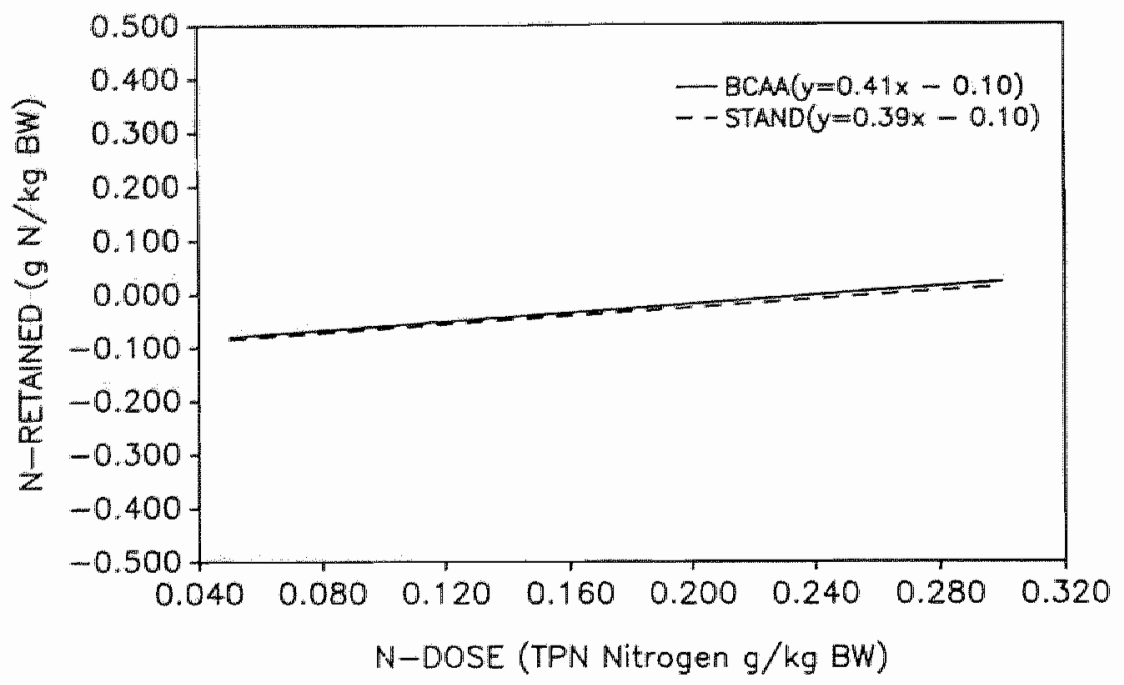

Figure 4.2 Regression lines between TPN derived nitrogen ( $/ \mathrm{kg} \mathrm{BW}$ ) and nitrogen balance $(\mathrm{g} / \mathrm{kg} \mathrm{BW})$ on any day in the BCAA group $\left(\mathrm{n}=343 ; \mathrm{r}=0.188 ; \mathrm{r}^{2}=0.035\right)$ and the standard group $\left(n=364 ; r=0.239 ; r^{2}=0.057\right)$. The slopes of both lines are not different, meaning that the administration of BCAA nitrogen does not result in an earlier achievement of nitrogen balance.

Table 4.5. Plasma proteins $(\bar{x} \pm$ sem)

\begin{tabular}{lllll}
\hline Day & & 0 & 4 & 7 \\
\hline Tot.prot. & BCAA & $56.4 \pm 1.4$ & $57.4 \pm 1.5$ & $61.1 \pm 1.3+$ \\
$g / 1$ & Stand & $58.3 \pm 1.4$ & $61.0 \pm 1.4$ & $64.9 \pm 1.1^{*}$ \\
& & & & \\
Albumin & BCAA & $26.0 \pm 0.9$ & $26.0 \pm 0.8$ & $26.9 \pm 0.8$ \\
$g / 1$ & Stand & $26.3 \pm 1.0$ & $27.1 \pm 1.0$ & $26.5 \pm 1.0$ \\
& & & & \\
Pre-Alb. & BCAA & $0.12 \pm 0.01$ & $0.14 \pm 0.01$ & $0.16 \pm 0.01^{*}$ \\
g/l & Stand & $0.11 \pm 0.01$ & $0.13 \pm 0.01$ & $0.14 \pm 0.01^{*}$ \\
& & & & \\
Tibc & BCAA & $26.7 \pm 1.6$ & $23.6 \pm 2.9$ & $30.2 \pm 2.6$ \\
$\mu$ mol/ & Stand & $27.3 \pm 1.3$ & $29.0 \pm 2.3$ & $31.9 \pm 1.9$ \\
\hline
\end{tabular}

+ ANOVA between study groups on each day $p<0.05$

* ANOVA across days per study group $p<0.05$ 
Table 4.6. Blood cell counts ( $\bar{x} \pm$ sem).

\begin{tabular}{lllll} 
Day & & 0 & 4 & 7 \\
\hline $\begin{array}{llll}\text { Leucoc } \\
\times 10^{9} / 1\end{array}$ & BCAA & $12.8 \pm 0.8$ & $13.6 \pm 1.1$ & $13.1 \pm 1.1$ \\
& Stand & $12.2 \pm 0.8$ & $12.7 \pm 0.7$ & $12.7 \pm 0.8$ \\
Band.sh & BCAA & $1.33 \pm 0.36$ & $1.39 \pm 0.35$ & $1.39 \pm 0.34^{*}$ \\
$\times 10^{9} / 1$ & Stand & $1.29 \pm 0.32$ & $0.74 \pm 0.13$ & $0.54 \pm 0.13$ \\
& & & & $1.87 \pm 0.15$ \\
Lympho & BCAA & $1.51 \pm 0.15$ & $1.58 \pm 0.14$ & $1.75 \pm 0.19^{*}$ \\
$\times 10^{9} / 1$ & Stand & $1.27 \pm 0.10$ & $1.64 \pm 0.16$ & 1.75 \\
& & & & $265 \pm 23^{*}$ \\
Thrombo & BCAA & $234 \pm 20$ & $243 \pm 19$ & $346 \pm 23^{*}$ \\
$\times 10^{9} / 1$ & Stand & $247 \pm 18$ & $272 \pm 22$ & \\
\hline
\end{tabular}

+ANOVA between study groups on each day $\mathrm{p}<0.05$

*ANOVA across days per study group $p<0.05$

\section{DISCUSSION}

Metabolism in traumatized and septic patients is characterized by increased proteolysis. Protein synthesis is also increased, albeit to a lesser degree. This results in a net protein breakdown and progressively negative nitrogen balance.

Accelerated protein degradation is reported to result from increased activity of lysosomal proteases, but the exact mechanism is unknown (Freund 1985, Hummel 1988) The branched-chain amino acids and especially leucine seem to have a regulatory effect on protein metabolism in vitro (Fulks 1975, Buse 1975) and in the perfused rat heart (Chua 1979). A stimulatory effect of the BCAA is reported on both hepatic and skeletal muscle protein synthesis in rats that are made septic (Hasselgren 1984, Hasselgren 1988, Mori 1988). The effect of BCAA on protein degradation is uncertain (Hasselgren 1984, Hasselgren 1988).

In sepsis and trauma glucose intolerance and increased insulin levels are well documented, leading to an energy shortage. It has been suggested that this energy shortage is partially covered by the degradation of BCAA in peripheral tissues (Gump 1974, Clowes 1976, O'Donnel 1976, Wichterman 1979).

Finally, in metabolic stress, sepsis and hepatic failure plasma amino acid profiles are characterized by decreased levels of most amino acids including the BCAA, but with the exception of the aromatic amino acids (Vente 1989). 
We tried to demonstrate in the current trial improved nitrogen efficiency as a result of the administration of a BCAA enriched TPN solution. We did so by assessing nitrogen balances, measuring plasma proteins and evolution of blood cell counts in an unselected patient population suffering from major illnesses that may be encountered in any major hospital.

The absence of a difference between the regression lines that presumably reflect efficiency of nitrogen metabolism suggests that BCAA enrichment of TPN solutions does not improve nitrogen metabolism. We observed a significant increase of pre-albumin, plasma total protein, lymphocytes and thrombocytes in the group receiving the standard amino acid solution, while neutrophil bands decreased significantly. In the BCAA group only pre-albumin values increased significantly across days. Nitrogen balances remained negative in both study groups throughout the 7-day study period, which has been observed previously (Larsson 1981)) and which is presumably the result of these patients being extremely ill. It may therefore be argued that BCAA enrichment would benefit specifically patients who have somewhat more stable disease, and who suffer moderate (20-50\%) stress, as defined by Kinney (Kinney 1970). Selection of such a subgroup, however, did not alter the above observations.

Thus, the changes demonstrated in the current trial suggest an advantage of the balanced standard solution over the BCAA enriched solution. A lower frequency of reoperations, intra-abdominal abscesses etc. in the standard group, could explain this advantage of the standard solution. However, careful assessment of the clinical data failed to confirm a less eventful course of disease in the standard group.

Until now two prospective randomized trials have been published investigating the effect of BCAA enrichment of TPN solutions in sufficiently large study populations (Cerra 1987, Okada 1988). In one study (Cerra 1987) patients with pancreatitis and organ failure were excluded. The general conclusion from that study of BCAA inducing a significantly improved nitrogen economy was based solely on the observation of a significantly improved nitrogen balance in the BCAA enriched group on one (the 4 th) day of the 7-day study. The second study reported a modest though not statistically significant improved nitrogen balance (Okada 1988). Furthermore, in this study patients in severely catabolic conditions were excluded.

The current study failed to support improved nitrogen metabolism efficiency in sepsis and trauma patients as a result of BCAA enrichment of standard TPN solutions. The results of this study confirm the view that improved nitrogen metabolism in sepsis and trauma patients is primarily dependent on the success of primary treatment (drainage of abscesses, debridement of necrotic tissue, stabilization of fractures etc,) rather than on supportive care. Under these conditions the 
effects of nutritional support, let alone the effects of a modification of nutritional support are limited. We conclude that BCAA enrichment of standard TPN solutions does not result in a more efficient nitrogen metabolism in sepsis and trauma patients. 


\section{REFERENCES}

Bonau R, Ang SD, Jeevanandam $M$, Daly JM. High-branched chain amino acid solutions: telationship of composition to efficacy. JPEN 8:622,1984.

Bower RH, Muggia-Sullam $M$, Vallgren $\$$, Hurst $J$, Kern KA, LaFrance $R$, Fischer JE. Branched-chain amino acid-enriched solutions in the septic patient Ann. Surg. 203:13, 1986.

$\mathbb{B}$ use $\mathrm{MG}$, Reid SS. Leucine, a possible regulator of protein turnover in muscle. J. Clin. Invest. $56: 1250,1975$.

Cerra FB, Mazuski B, Teasly K, Nuwer N, Lysne J, Shronts EP, Konstantinides FN. Nitrogen retention in critically ill patients is proportional to the branched-chain amino acid load. Crit. Care Med. 11:775,1983.

Cerra F, Blackburn $\mathrm{G}_{*}$ Hirsch $J$, Mullen $K$, Luther W. The effect of stress level, amino acid formula and nitrogen dose on nitrogen retention in traumatic and septic stress. Ann. Surg. $205: 282,1987$.

Chua B, Siehl DI, Morgan HE. Effect of leucine and metabolites of branched-chain amino acids on protein turnover in heart. J. Biol. Chem. 254:8358, 1979.

Clowe GHA, O'Donnell TF, Blackburn GL, Maki TN. Energy metabolism and proteolysis in traumatized and septic man. Surg. Clin. North Am. 56:1169,1976.

Freund $\mathrm{H}$, Ryan $\mathrm{J}$, Fischer J. Amino acid derangements in patients with sepsis. Treatment with branched chain amino acid rich infusions. Ann. Surg. 188:423,1978.

Freund $H$, Hoover $H$, Atamian $S$, Fischer J. Infusion of the branched-chain amino acids in postoperative patients. Ann. Surg. 190:18,1979.

Freund $\mathrm{H}$, Muggia-Sullam M, Lafrance $\mathrm{R}$. Muscle prostaglandin production in rat. Effect of abdominal septis and different amino acid formulations. Arch. Surg. 120:1037,1985.

Freysz H, Caillard B, Desgres J. Are branched-chain amino acids beneficial for nutrition of severe surgical patients with sepsis?. Clin. Nutr. 8:61,1989.

Fulks RM, Li JB, Goldberg AL. Effects of insulin, glucose, and amino acids on protein turnover in rat diaphragm. J. Biol. Chem. 250:290,1975.

Gump FE, Long C, Killian P. Kinney JM. Studies of glucose intolerance in septic injured patients. J. Trauma 14:378,1974.

Hasselgren P, Jagenburg R, Karlström L, Pedersen P, Seeman T. Changes of protein metabolism in liver and skeletal muscle following trauma complicated by sepsis. J. Trauma 24:224,1984.

Hasselgren, P, James H, Warner B, Fischer JE. Protein synthesis and degradation in skeletal muscle from septic rats. Response to leucine and $\alpha$-ketoisocaproic acid. Arch. Surg. $123: 640,1988$.

Hummel R, James H, Warner B. Evidernce that Cathepsin B contributes to skeletal muscle protein breakdown during sepsis. Arch. Surg. 123:221,1988.

Kern KA, Bower RH, Atamian S, Matarese LE, Ghory MJ, Fischer JE. The effect of a new branched-chain-enriched amino acid solution on postoperative catabolism. Surg. $92 \times 780,1982$.

Kinney JM, Duke Jr. JH, Long CL, Gump FE. Tissue fuel and weight loss after injury, J. Clin. Path. 23 (suppl 4):65, 1970.

Larsson J, Liljedahl S-O, Schildt B, Fürst $\mathrm{P}$, Vinnars E. Metabolic studies in multiple injured patients. Acta Chir. Scand. 147:317,1981.

Mori E, Hasebe M, Kobayaski K. Effect of total parenteral nutrition enriched in branched-chain amino acids on metabolite levels in septic rats. Metabolism 37:824,1988. 
Nuwer N, Cerra FB, Shronts EP, Lysne J, Teasly KM, Konstantinides FN. Does modified amino acid total parenteral nutrition alter immune response in high level surgical stress. JPEN $7: 521,1983$.

O'Donnel TF, Clowes GHA, Blackbum GL, Ryan T, Benotti PN, Miller JDB. Proteolysis associated with a deficit of peripheral energy fuel substrates in septic man. Surg. 80: 192, 1976.

Okada A, Mori S, Totsuka M, Okamoto K, Usui S, Fujiti H, Itakura T, Mizote H. Branchedchain amino acids metabolic support in surgical patients: A randomized, controlled trial in patients with subtotal or total gastrectomy in 16 Japanese institutions. JPEN 12:332,1988.

Vente JP, von Meyenfeldt MF, van Eijk HMH, van Berlo CLH, Gouma DJ, Van der Linden CJ, Soeters PB. Plasma amino acid profiles in sepsis and stress. Ann. Surg. 209:57, 1989.

Wichterman KA, Chaudry IH, Baue AE. Studies of peripheral glucose uptake during sepsis. Arch. Surg. 114:740,1979. 



\section{Chapter 5}

\section{Plasma amino acid profiles in sepsis and stress}

\section{SUMMARY}

Sepsis has been associated with specific plasma amino acid patterns. We prospectively investigated in 65 patients whether these patterns are indeed sepsis specific, or specific for metabolic stress without concomitant sepsis, or associated with the presence of organ failure. Virtually all amino acid levels were 10-30\% decreased $(p<0.05)$, whereas cystine and phenylalanine were significantly elevated. These changes were more pronounced in severe sepsis. Organ failure was not associated with significantly altered amino acid profiles. No differences were found between sepsis and stress without signs of sepsis. In addition, imminent death was not associated with aberrant amino acid profiles. We conclude that sepsis and metabolic stress are associated with changes in plasma amino acid profiles, but that such changes are aspecific and therefore poor indicators of disease severity.

\section{INTRODUCTION}

Sepsis and stress are associated with changes in metabolism that result in net proteolysis and negative nitrogen balance (O'Donnel 1976). In addition, amino acid concentrations in plasma change. Many explanations have been proposed in literature, often focussed around protein degradation, but rarely offering data supporting the mechanisms suggested. It should be pointed out that although free amino acids in the peripheral blood stream represent a balance between the amino acid flux over skeletal muscle and the amino acid flux over visceral organs, they do not reflect turnover. There is no consensus as to whether changes in plasma amino acid profiles and ratios are specific in sepsis and stress. Some authors report a hypoaminoacidemia (Askanazi 1980, Clowes 1980, Stinnet 1982, Roth 1985, Iapichino 1988, Freysz 1989), others observe no changes (Rosenblatt 1983) or an increase in total amino acid concentration (Freund 1978, Freund 1979). 
Many authors have reported plasma amino acid profiles that were claimed to be specific for sepsis. Mosit authors find a significant increase of phenylalanine (Wannemacher 1977, Freund 1978, Cerra 1979, Freund 1979, Askanazi 1980, Clowes 1980, Stinnet 1982, Rosenblatt 1983, Tapichino 1988, Freysz 1989). It has even been suggested that a correlation exists between phenylalanine levels and mortality (Freund 1979, Stinnett 1982, Rosenblatt 1983). The plasma concentration of the other two aromatic amino acids (AAA) tryptophan and tyrosine are frequently elevated (Freund 1978, Freund 1979). The same applies to the sulfurcontaining amino acids, especially methionine (Freund 1979, Clowes 1980, Rosenblatt 1983). The branched-chain amino acid (BCAA) concentrations are most often decreased (Wannemacher 1977, Clowes 1980), but normal (Freund 1978, Freund 1979) or increased concentrations (Cerra 1979') are also described. Elevated plama-levels are reported for alanine (Freund 1978), proline (Freud 1978), arginine (Freund 1979) and taurine (Rosenblatt 1983). Studies by Border in septic patients reveiled an increased splanchnic clearance of tryptophan and proline and release of glutamate, which is a metabolite of proline (Border 1976). Cerra found that proline was significantly elevated in sepsis and a good indicator of mortality. The plasma levels of amino acids involved in the hepatic pathways of proline metabolism (glutamate and ornithine) were found to be elevated in proportion to proline in terminally ill septic patients. (Cerra 1979b). As these discrepancies may partly be explained by the heterogeneity of the patients investigated, we undertook a prospective study to establish the relationship between plasma amino acid profiles and the severity of sepsis or stress that was as carefully defined as possible. In addition, we studied plasma amino acid profiles during sepsis as opposed to metabolic stress with no evident sepsis, during isolated hyperbilirubinemia, during renal failure and in patients that were about to die from sepsis. These factors were specifically studied, because they may influence protein metabolism and consequently plasma amino acid patterns.

\section{PATIENTS AND METHODS}

\section{Patients}

Sixty five patients with sepsis and/or stress, 38 males and 27 females, were studied. All patients were treated in the intensive care unit. Sepsis was defined as the presence of a combination of the following criteria: spiking body temperature, hyperventilation, tachycardia, elevated white blood cell counts, decreased blood pressure, decreased urinary output, positive blood cultures. A clinically manifest septic focus was considered obligatory. Patients suffering from multitrauma, 
ruptured aneurysm of the abdominal aorta, or severe pancreatitis were considered metabolically stressed patients in the absence of the afore mentioned sepsis criteria (table 5.1).

Table 5.1 List of diagnoses of 65 patients with sepsis $(n=27)$ and stress $(n=38)$

\begin{tabular}{lrrr} 
& Sepsis & Stress & Total \\
\hline Perforated viscera / anastomotic leakage & 12 & 7 & 19 \\
Pancreatitis & 3 & 12 & 15 \\
Multiple injuries & 1 & 4 & 5 \\
Esophagus resections & 2 & & 2 \\
Pancreaticoduodenectomies & 1 & 1 & 2 \\
Ruptured AAA & 2 & 6 & 8 \\
Enterocolitis (Crohn etc.) & 3 & 3 & 6 \\
Other & 3 & 5 & 8 \\
Total & & & 65 \\
\hline
\end{tabular}

\section{Severity of disease}

The severity of disease was assessed in two ways:

1. The catabolic index according to Bistrian (Bistrian 1979). This index considers urinary urea excretion to consist of an obligatory portion derived from dietary protein, and of a portion that is derived from endogenous protein catabolism. Thus, the catabolic index amounts to 24 hour urinary urea $\mathrm{N}$ excretion ( $0.5 \times$ dietary $\mathrm{N}$-intake +3 grams), where it is assumed that 50 percent of protein intake is utilized and that the obligatory urine nitrogen excretion amounts to 3 grams. Bistrian catabolic indices in the current study were somewhat higher than originally described because total urinary nitrogen values were available, instead of urea nitrogen values. In this study patients were divided into 3 groups:

mildly catabolic:

$$
<3
$$

moderately catabolic:

severely catabolic:

$$
>8
$$


2. The grading of sepsis as proposed by Elebute and Stoner (Elebute 1983) This scoring system consists of four chapters: clinical criteria (wound infection, presence of localized or generalized peritonitis etc.) pyrexia, secondary effects of sepsis (metabolic acidosis, renal failure etc.) and laboratory data (leucocytosis, platelet counts etc.). Each chapter's score is higher as derangements are more pronounced (table 2.4). They are added up to result in the sepsis score. Based on Elebute and Stoner"s report patients were divided into three grades of sepsis severity:

$\begin{array}{lc}\text { mild sepsis: } & <10 \\ \text { moderate sepsis: } & 10-20 \\ \text { severe sepsis: } & >20\end{array}$

\section{Organ function}

Plasma bilirubin levels were considered only in the absence of primary hepato biliary disease. Three categories were defined:

1. $0-17 \mu \mathrm{mol}$ per liter

2. 17-68 $\mu \mathrm{mol}$ per liter

3. over $68 \mu \mathrm{mol}$ per liter

Renal function was assessed employing creatinin clearance, expressed as percentage of estimated pre-disease levels. These were derived from a nomogram that considers serumcreatinine as well as weight, sex and age (Siersbaek-Nielsen 1971). Three levels of renal function were distinguished:

1. Creatinin clearance $>100 \%$

2. Creatinin clearance $75-100 \%$

3. Creatinin clearance $<75 \%$

of estimated pre-disease levels.

\section{Laboratory determinations}

Blood samples were drawn after an ovemight fast for determination of amino acids, hematocrit and albumin according to standard laboratory procedures. Patients had not received enteral or parenteral nutrition at least $24 \mathrm{hr}$ prior to sampling. Normal plasma amino acid concentrations were determined in blood samples drawn from a group of thirty healthy persons with a maximum age of 65 years after a $12 \mathrm{hr}$ fast. Results were statistically evaluated with one way and two way ANOVA's. 


\section{RESULTS}

Most amino acids were significantly depressed $(\mathrm{p}<0.05)$ compared to control values (fig. 5.1). Glutamine and citrulline amounted to $50 \%$ and $30 \%$ of nomal values respectively. Methionine and tyrosine concentrations were normal, while cystine and phenylalanine levels were $125 \%$ and $170 \%$ of normal levels. Hematocrit and albumin were decreased by $15-30 \%$. No significant differences appeared when amino acid profiles of septic patients were compared with those of stressed, but not septic patients (fig. 5.2). No differences could be detected when patients were divided according to the Bistrian catabolic index. Levels of branched-chain amino acids, sulfurcontaining amino acids, citrulline and alanine were not different between the three degrees of catabolism. In the severely catabolic group glycine levels decreased significantly compared to the mild stress group and tyrosine levels increased significantly compared to the mild and moderate stress group (fig. 5.3). When sepsis was graded as proposed by Elebute and Stoner no differences were evident between mild and moderate sepsis with the exception of taurine levels that were increased $(p<0.05)$ in moderately septic patients. In severely septic patients virtually all amino acids were increased as compared to the mildly and moderately septic groups. This increase was signifi-

PLASMA AA PROFILES IN SEPSIS/STRESS

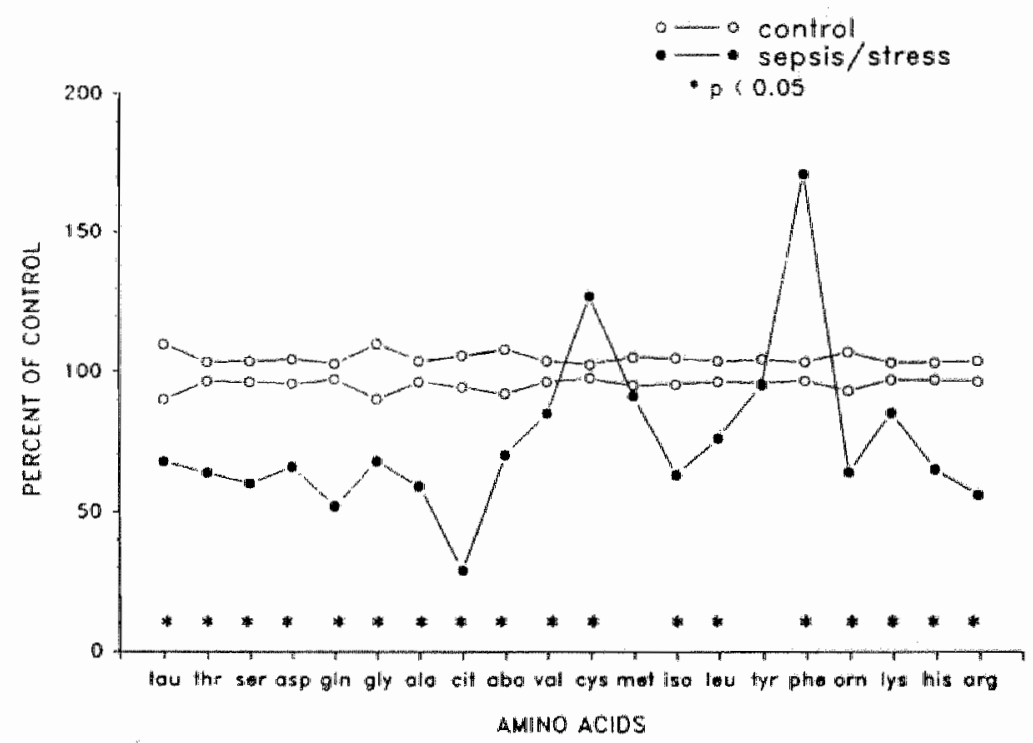

Figure 5.1 Mean plasma amino acid levels, expressed as percent of normal values in 65 patients with sepsis and/or stress. The area between the open symbols represents normal ( \pm sern) values. 


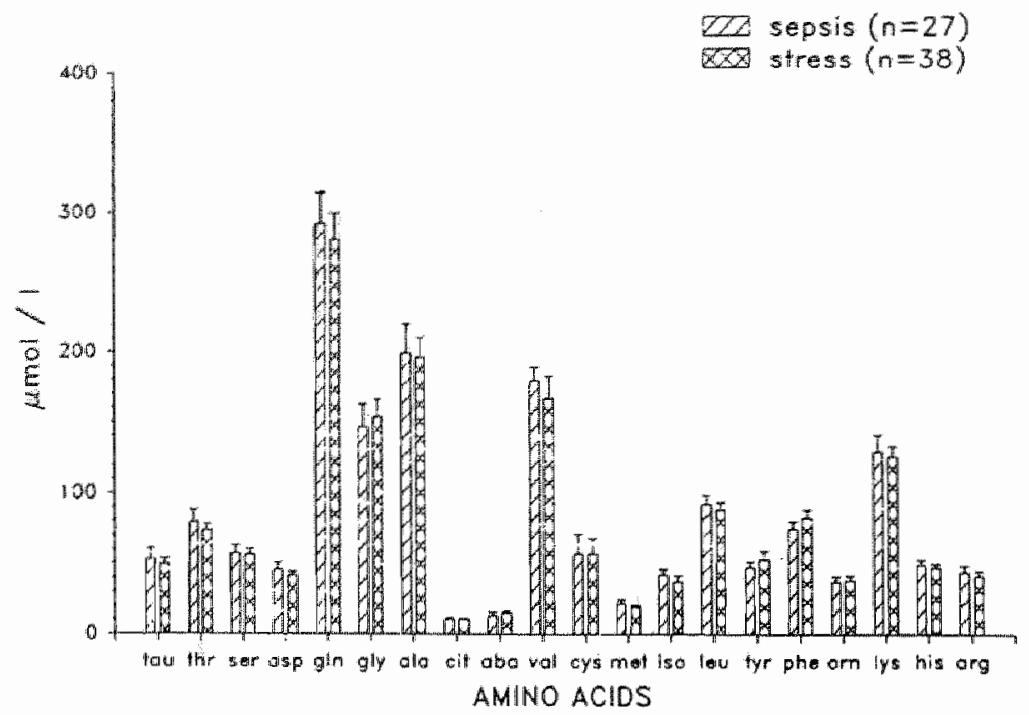

Figure 5.2 No significant change in plasma amino acid profiles of septic patients (right hatched bars) may be observed when compared to profiles of stressed, but not septic patients (cross hatched bars) (values are $x \pm$ sem).

PLASMA AA PROFILES IN STRESS

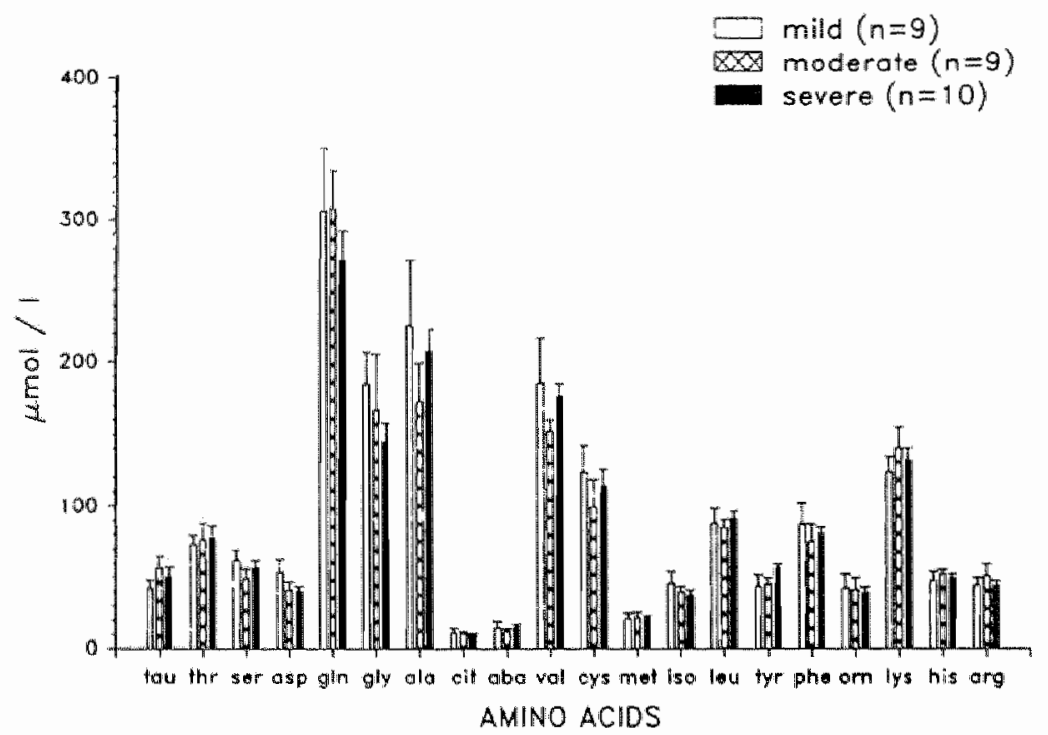

Figure 5.3 Plasma amino acid concentrations ( $x \pm$ sem) in mild, moderate and severe catabolic state, calculated according to Bistrians method. No significant differences arise when patients are divided according to the severity of catabolism. 


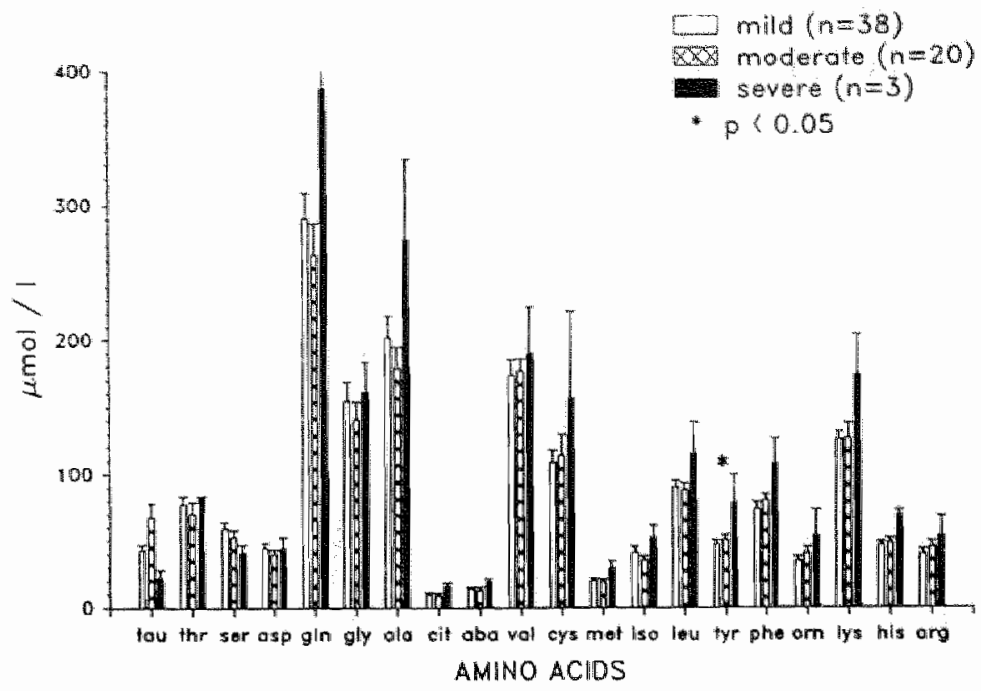

Figure 5.4 Plasma amino acid concentrations ( $x \pm$ sem) in mild, moderate and severe sepsis determined by the Elebute and Stoner scores. In severely septic patients virtually all amino acids increase, but only significantly $(p<0.05)$ for tyrosine.

cant ( $p<0.05$ ) only for tyrosine levels (fig. 5.4). Taurine was significantly decreased. A point of concern is, however, that the severely septic group comprised only 3 patients. Hematocrit and albumin values were $65 \%-80 \%$ of normal in all sepsis score categories. The BCAA/AAA ratio decreased with increasing severity of sepsis (fig. 5.5) although this trend did not become statistically significant. This ratio remained unchanged with increasing catabolic stress. The PHE/TYR ratio was increased in the patient group as compared to controls (table 5.2). Increasing sepsis did not change this ratio, but increasing severity of metabolic stress was associated with a decreased ratio. Increasing hyperbilirubinemia was not associated with an alteration of amino acid profiles (fig. 5.6). Specifically sulfurcontaining and aromatic amino acid concentrations are claimed to increase in liver disease, but these were not affected in this study. The sulfur containing amino acids taurine and cystine increased with increasing severity of renal failure. Glutamine and alanine increased significantly in mild renal failure (fig. 5.7). Amino acid profiles in isolated hyperbilirubinemia or isolated renal failure, or a combination of both were compared with the group displaying neither liver nor renal failure. Only small differences were detected in the presence of organ failure, including decreases of all amino acid concentrations except for taurine levels that remained normal in the presence of isolated renal failure. 


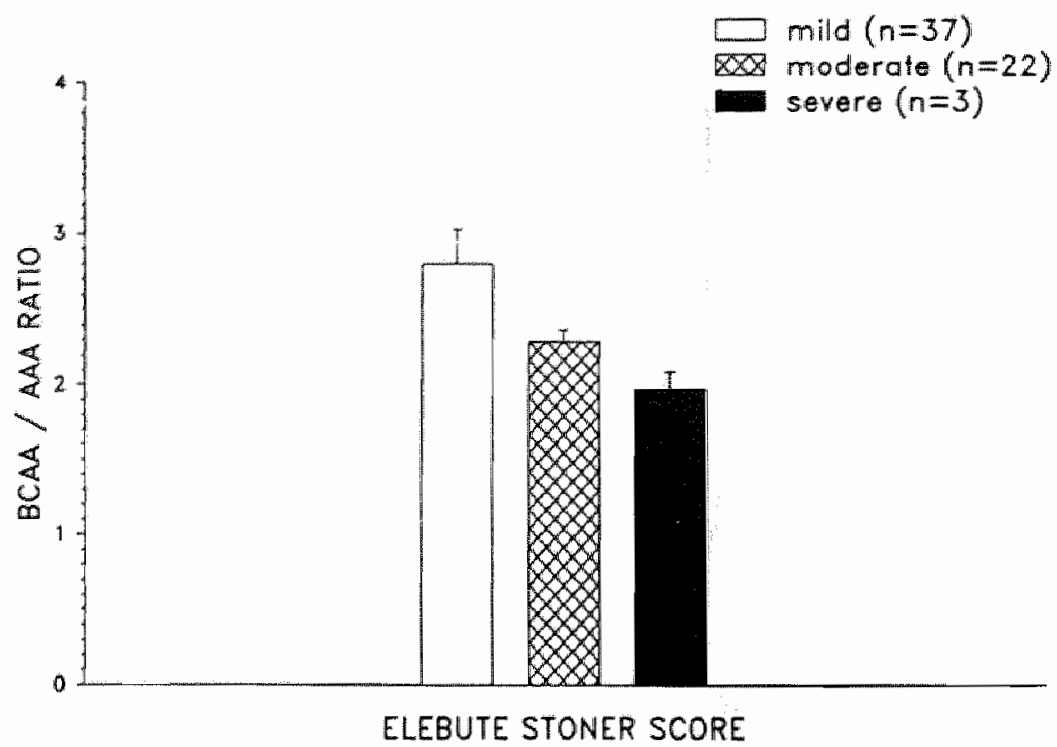

Figure 5.5 BCAA/AAA ratio's ( $x \pm$ sem) decrease with increasing severity of sepsis.

PLASMA AA PROFILES IN HYPERBILIRUBINEMIA

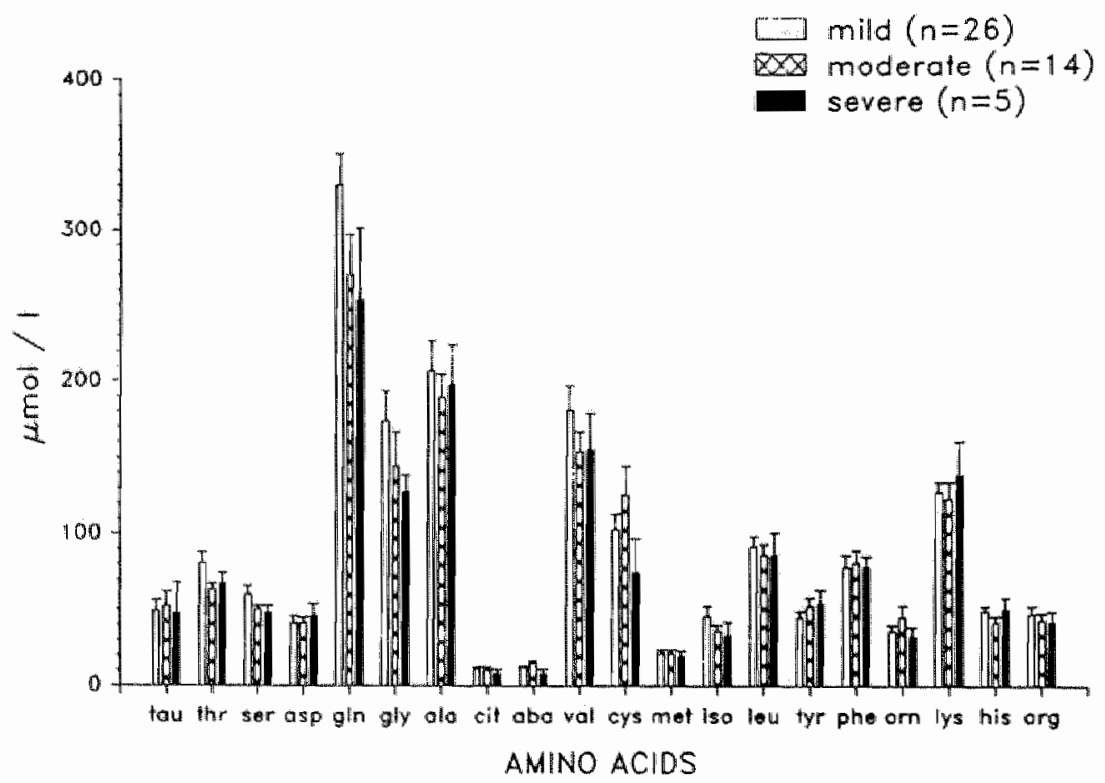

Figure 5.6 Mild, moderate or severe hyperbilirubinemia is not associated with an altered amino acid profile $(x \pm$ sem). 
Total group

Metabolic stress (Bistrian)

$$
\begin{array}{ll}
\text { mild } & (n=9) \\
\text { moderate } & (n=10) \\
\text { severe } & (n=31)
\end{array}
$$

$1.71 \pm 0.11$

$2.17 \pm 0.38$

$1.85 \pm 0.46$

$1.50 \pm 0.08$

Sepsis (Elebute and Stoner)

$\begin{array}{lll}\text { mild } & (n=40) & 1.70 \pm 0.15 \\ \text { moderate } & (n=22) & 1.75 \pm 0.16 \\ \text { severe } & (n=3) & 1.48 \pm 0.21\end{array}$

PLASMA AA FROFILES IN RENAL FAILURE

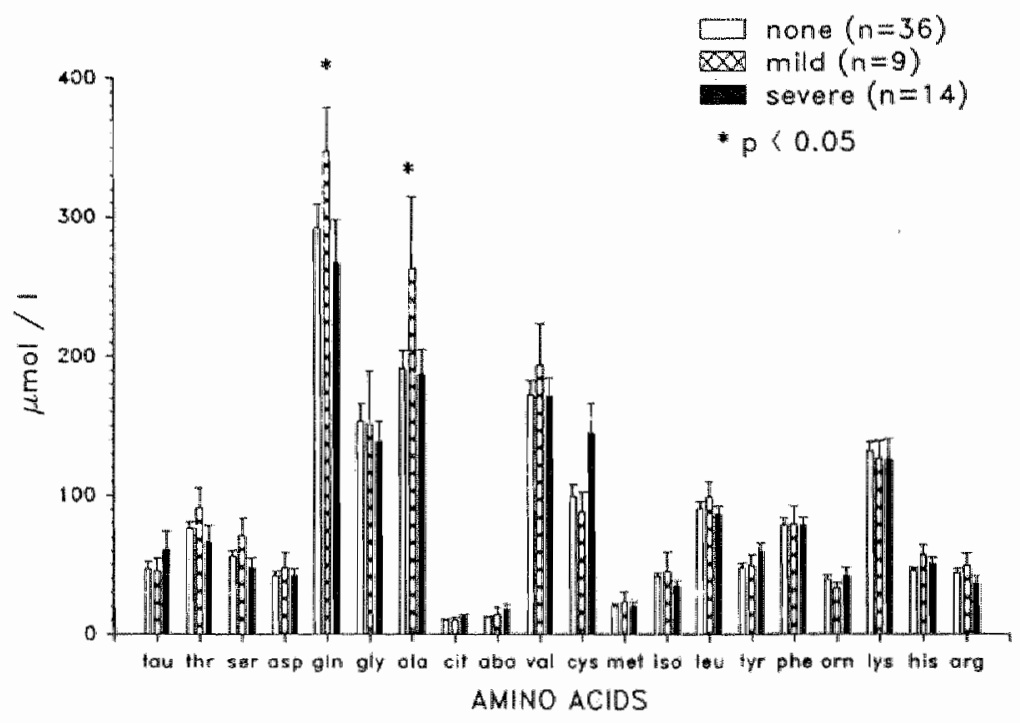

Figure 5.7 Increasing severity of renal failure induces increased taurine and cystine levels although not significant. In mild renal failure glutamine and alanine are significantly increased $(x \pm$ sem).

Branched-chain amino acid concentrations decreased in the presence of organ failure (fig. 5.8). Amino acid profiles of patients dying from sepsis within one week from the drawing of blood samples, exhibited minor differences with AA profiles of surviving patients. Only taurine levels increased significantly in patients dying of causes related to sepsis (fig. 5.9). 


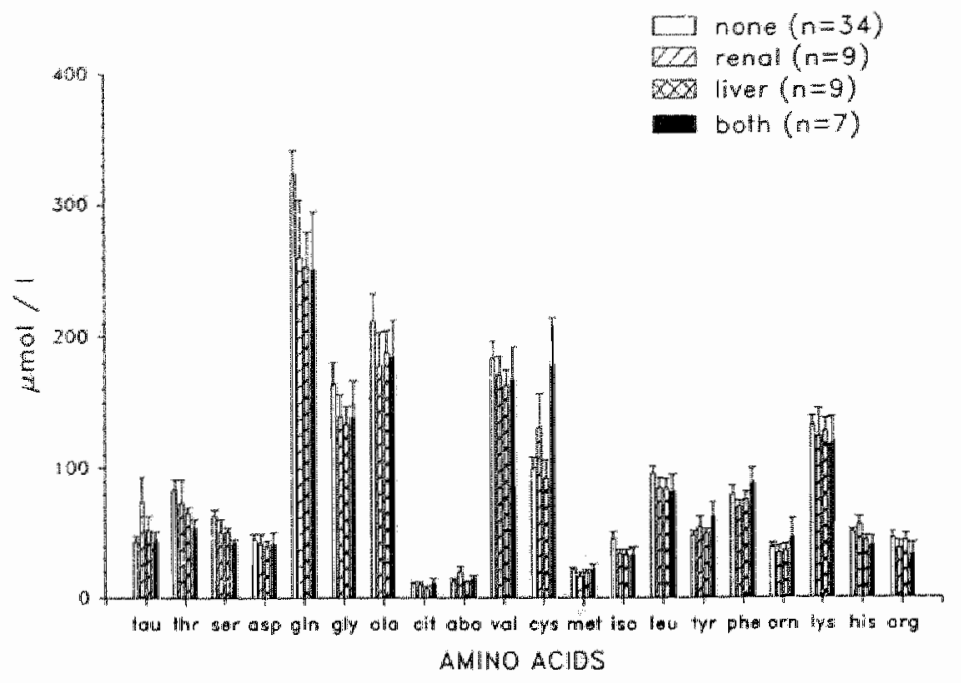

Figure 5.8 Plasma amino acid profiles $(x \pm$ sem) in patients with isolated renal failure (right hatched bars), isolated hepatic failure (cross hatched bars) and patients with a combination of both organ systems failing (black bars) show no significant differences, with those of patients without organ failure (blank bars).

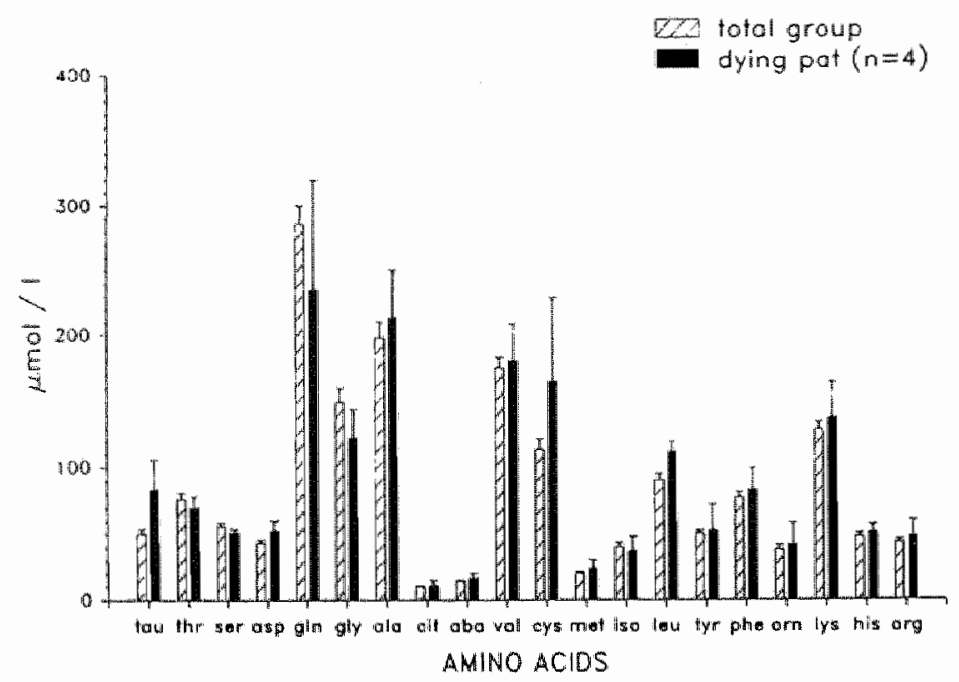

Figure 5.9 Amino acid profiles $(x \pm$ sem) of patients dying from sepsis within one week from the drawing of blood samples, show only minor differences with amino acid profiles of the total group. 


\section{DISCUSSION}

Plasma amino acids constitute a small, rapidly tuming over pool that constitutes only $10 \%$ of the total free amino acid pool which in turn comprises only 5-6\% of all amino acids present in the body in bound or free form. Altered amino acid flux and/or metabolism is not necessarily accompanied by changes in plasma amino acid levels (Wilmore 1980). Alternately, changes in plasma amino acids do not necessarily reflect changes in amino acid turnover. Plasma amino acid levels should therefore be interpreted with caution.In this study we tried to establish whether plasma amino acid levels during severe sepsis or stress had any specific meaning, once sepsis and stress were defined as carefully as possible. Hypoaminoacidemia was observed for virtually all amino acids in the current study, as has been described previously (Askanazi 1980, Clowes 1980, Stinnett 1982). The mechanism underlying this hypoaminoacidemia is not well understood. The hypoaminoacidemia we observed was accompanied by a 15 to $30 \%$ decrease of hematocrit and albumin concentrations. Fasting in itself induces such changes only after prolonged periods. Because our patients had not fasted long periods before starting the study, the nature of acute illness is a more likely explanation. The increase of total body water, and especially the extracellular component, leads to hemodilution (Abbott 1983), and may thus contribute to the decrease of hematocrit, albumin and amino acid values. Hasselgren (Hasselgren 1984) described changes in plasma alanine, ormithine, phenylalanine and histidine levels in an animal model of trauma with sepsis. No differences in amino acid profiles were observed in trauma as compared to the control group. In contrast to these observations amino acid concentrations in septic patients were in the current study not distinct from those in stressed patients without sepsis. Significantly increased cystine and phenylalanine and normal tyrosine and methionine concentrations were recorded compared to normal controls. Increasing severity of sepsis was accompanied by increasing phenylalanine concentrations if sepsis was graded according to Elebute and Stoner. Such correlations were not observed in connection with the catabolic index score. Elevated plasma phenylalanine levels are described by many authors (Freund 1978, Freund 1979, Askanazi 1980, Clowes 1980, Stinnett 1982, Rosenblatt 1983). Stinnett (Stinnett 1982) observed phenylalanine levels in excess of $120 \%$ of normal values to be predictive of death as early as one to two days prior to the patient's dying. It has been proposed that the phenylalanine-tyrosine ratio gives a fair estimate of the activity of inflammatory disease and the catabolic state of a patient (Wannemacher 1976). In the current study, a marked elevation of this ratio was also observed, but the ratio was not related to the severity of sepsis and stress. Glutamine and alanine are of special interest as these amino acids represent two-thirds of the total amount of 
amino acids released from muscle (Garber $1976^{2}$ ). Release from muscle of other amino acids like the branched-chain amino acids, cystine, methionine, serine, threonine, glycine and lysine will induce de novo synthesis of alanine and glutamine. This results in a disproportionally high efflux of alanine and glutamine from muscle (Odessey 1974, Garber 1976 ${ }^{a}$, Garber 1976 ${ }^{b}$ ). In our study glutamine values were $50 \%$ decreased. Askanazi (Askanazi 1980) also observed severly depressed glutamine values in muscle and plasma of septic patients. Alanine concentrations appeared to be decreased in plasma, as has been observed by others (Roth 1982). In the present study branched-chain amino acid (BCAA) concentrations were decreased, although the ratio between the BCAA remained normal. This is a common observation (Wannemacher 1977, Freund 1978, Freund 1979, Clowes 1980). Dividing the patients in our study according to the Elebute and Stoner sepsis score, a decrease of the ratio between plasma branchedchain amino acids and aromatic amino acids results as the severity of sepsis increases. During liver failure such decreasing BCAA-AAA ratio's have also been found (Mizock 1985). This study demonstrates that a decrease of the BCAA-AAA ratio also occurs during sepsis and stress although the levels reported during hepatic failure (Fischer 1976) are not reached. Patients that died had high plasma bilirubin levels. It is well known, however, that hyperbilirubinemia develops after longstanding sepsis. In the present study hyperbilirubinemia did not correlate with specific plasma-amino acid profiles, even not with decreased BCAA-AAA ratio's. This suggests that elevated plasma bilirubin levels do not coincide with diminished hepatic function. Taurine concentrations are decreased approximately $30 \%$ in sepsis and stress. However, in patients with acute renal failure and end-stage sepsis plasma levels normalized. This is in concord with the finding, that increased plasma taurine concentrations occur in chronic renal failure (Mitch 1983). The current study failed to demonstrate significant differences between plasma amino acid profiles of patient groups divided according to the catabolic index score. Plasma amino acid profiles of patients, who were midly or moderately septic according to the Elebute and Stoner score were not distinct from each other, even if compared with normal controls. In severe sepsis virtually all amino acids were increased if compared to mildly or moderately septic patients, although only elevations of tyrosine concentrations reached significance. This may have been caused by the small number of patients in this group. We therefore conclude that sepsis and metabolic stress are associated with changes in plasma amino acid profiles, notably decreased concentrations. A specific sepsis pattern, as opposed to a metabolic stress pattem could not be identified, although increasing sepsis severity, as evidenced by higher Elebute and Stoner scores seemed to be associated with more pronounced aberra- 
tions. Progressing organ failure and imminent death were not associated with altered plasma amino acid patterns. Thus, plasma amino acid patterns are poor indicators of disease severity. 


\section{REFERENCES}

Abbot W, Echenique M, Bistrian B, Williams S, Blackbum $G$. Nutritional care of the trauma patient. Surg Gynecol Obstet 157:585-597,1983.

Askanazi J, Carpentier X, Michelsen C, Elwyn D, Furst P, Kantowitz L, Gump F, Kinney J. Muscle and plasma amino acids following injury. Ann Surg 192:78-85,1980.

Bistrian B. A simple technique to estimate severity of stress. Surg Gynecol Obstet 148:675678,1979 .

Border J, Chenier R, MoMenamy R, La Duca J, Seibel R, Birkhahn R, Yu L. Multiple systems organ fallure: muscle fuel deficit with visceral protein malnutrition. Surg Clin N Am 56 $5: 1147-1167,1976$.

Cerra F, Sieggel J, Border J, Wiles J, McMenahy R. The hepatic failure of sepsis: cellular versus substrate. Surgery $86: 409-422,1979^{*}$.

Cerra $\mathrm{F}$, Capriol J, Siegel J, McMenamy $\mathrm{R}$, Border J. Proline metabolism in sepsis, cirrhosis and general surgery. The peripheral energy deficit. Ann Surg 190:577-586,1979 ${ }^{\mathrm{b}}$.

Clowes $\mathrm{G}$, Randall $\mathrm{H}$, Cha $\mathrm{C}$. Amino acid and energy metabolism in septic and traumatized patients. JPEN 4:195-205,1980.

Elebute $\mathrm{E}$, Stoner H. The grading of sepsis. Br J Surg 70:29-31,1983.

Fischer J, Rosen H, Abeid A. et al: The effect of normallization of plasma amino acids on hepatic encephalopathy in man. Surgery 80:77-91,1976.

Freund $\mathrm{H}$, Ryan J, Fischer J. Amino acid derangements in patients with sepsis: treatment with branched-chain amino acid rich infusions. Ann Surg 188:423-430, 1978.

Freund $\mathrm{H}$, Atamian $\mathrm{S}$, Holroyde J, Fischer J. Plasma amino acids as predictors of the severity and outcome of sepsis. Ann Surg 190:571-576,1979.

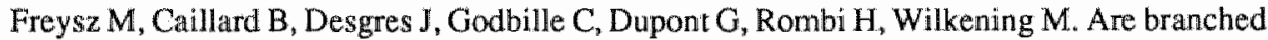
chain amino acids beneficial for nutrition of severe surgical patients with sepsis. Clin Nutr $8: 61-67,1989$.

Garber A, Karl I, Kipnis D. Alanine and glutamine synthesis and release from skeletal muscle. The precursor role of amino acids in alanine and glutamine synthesis. J Biol Chem 251:836$843,1976^{\mathrm{a}}$.

Garber A, Karl I, Kipnis D. Alanine and glutamine synthesis and release from skeletal muscle. Glycolysis and amino acid release. J Biol Chem 251:826-835,1976 .

Hasselgren P, Jagenburg R, Karlström L, Pedersen P, Seeman T. Changes of protein metabolism in liver and skeletal muscle following trauma complicated by sepsis. J Trauma 24:224228,1984

Iapichino $G$, Radrizzani $D$, Scherini $A$, Malacrida $R$, Bonetti $G$, Leoni L, Della Torre P, Ronzoni $\mathrm{G}$, Colombo A, Marengo M, Damia $G$. Essential and non-essential amino acid requirement in injured patients receiving total parenteral nutrition. Int Care Med 14:399. 405, 1988 .

Mitch W. Amino acid analogues: metabolism and use in patients with chronic renal failure. In: Blackburn G, Grant J, Young V, eds. Amino acids. Metabolism and medical applications. Boston, Bristoll etc.: John Wright, 439-450, 1983.

Mizock B. Branched-chain amino acids in sepsis and heparic failure. Arch Int Med 145:1284$1288,1985$.

O'Donnell T, Clowes G, Blackburn G, Ryan N, Benotti P, Miller J. Proteolysis associated with a deficit of peripheral energy fuel substrates in septic man. Surgery 80:192-200,1976. 
Odessey $R$, Khairallah $E$, Goldberg $A$. Origin and possible significance of alanine production by skeletal muscle. J Biol Chem 249:7623-7629,1974.

Rosenblatt S, Clowes G, George B, Hirsch E, Lindberg B. Exchange of amino acids by muscle and liver in sepsis. Arch Surg 118:167-175,1983.

Roth E, Funovics J, Mühlbacher F, Schemper M, Mauritz W, Sporn P, Fritsch A. Metabolic disorders in severe abdominal sepsis: glutamine deficiency in skeletal muscle. Clin Nut 1:25-41,1982.

Roth E, Zöch G, Schulz F, Karner J, Mühlbacher F, Hamilton G, Mauritz W, Sporn P, Funovics J. Amino acid concentrations in plasma and skeletal muscle of patients with acute hemorrhagic necrotizing pancreatitis. Clin Chem 31:1305-1:309,1985.

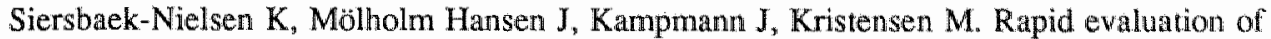
creatinine clearance. Lancet 1:1133-1134,1971.

Stinnett $J$, Alexander W, Watanabe C, MacMillan B, Fischer I, Morris M, Trocki O, Miskell $P$, Edwards L, James. H. Plasma and skeletal muscle amino acids following severe burm injury in patients and experimental animals. Ann Surg 195:75-89,1982.

Wannemacher R, Klainer A, Dinterman R, Beisel W. The significance and mechanism of an increased serum phenylalanine-tyrosine ratio during infection. Am J Clin Nutr 29:997$1006,1976$.

Wannemacher R. Key role of various individual amino acids in host response to infection. Am J Clin Nutr 30:1269-1280,1977.

Wilmore D, Goodwin C, Aulick L, Powanda M, Mason A, Pruitt B. Effect of injury and infection on visceral metabolism and circulation. Ann Surg 192:491-500,1980. 


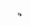




\section{Effects of infusion of branched-chain amino acids enriched TPN solutions on plasma amino acid profiles in sepsis and trauma}

\section{SUMMARY}

Total parenteral nutrition with branched-chain amino acids enriched solutions has been advocated in patients with sepsis and stress because of favourable effects on nitrogen balance, protein synthesis and immune competence. The rationale for the use of BCAA-enriched solutions is based on their potential to correct the plasma amino acid imbalances seen in these patients. In a seven day prospective randomized study we investigated the effects on plasma amino acid concentrations of a standard amino acid solution (15,6\% BCAA) and a branched-chain amino acid enriched solution (50,2\% BCAA) in 101 parenterally fed patients with as carefully as possible assessed sepsis and/or stress.

The infusion of the BCAA-enriched solution led to an imbalance of the essential plasma amino acids. The branched-chain amino acids valine, leucine and isoleucine increased significantly while the non-BCAA essential amino acids decreased significantly. In the standard solution the non-BCAA-essential amino acids increased significantly with slower, not significantly rising levels of the branched-chain amino acids. We conclude that infusion of a BCAA enriched TPN formulation induced amino acid profile derangements that can be considered ill-suited to achieve anti-catabolic effects.

\section{INTRODUCTION}

Metabolic alterations in sepsis and stress are characterized by reduced protein synthesis, increased proteolysis and gluconeogenesis leading to a progressively negative nitrogen balance (Clowes 1976). Enteral or parenteral nutrition may 
increase protein synthesis and restore immune competence (Mizock 1985). In recent years the role of the branched-chain amino acids (BCAA) has been the focus of intense research. Freund (Freund 1978') ascribed three properties of the BCAA that could be used to reduce postinjury catabolism: energy substrate for skeletal muscle, substrate for alanine and glutamine synthesis and inhibition of amino acid flux from muscle. Fischer (Fischer 1976) observed similar changes of plasma amino acid concentrations in sepsis, as in patients with hepatic encephalopathy: increased aromatic amino acid concentrations and a fall in concentrations of the BCAA. The assumption that in sepsis and trauma a plasma amino acid profile exists that is the result of altered protein metabolism (Askanazi $1980^{\circ}$ ) has led to the use of amino acid solutions designed to correct this amino acid profile to resemble a post prandial amino acid profile (Fischer 1976). Therefore, we performed a prospective randomized double blind trial investigating the potential of a branched-chain amino acid enriched TPN solution to correct plasma amino acid imbalances in septic or metabolically stressed patients.

\section{PATIENTS AND METHODS}

\section{Patients}

Both septic and metabolically stressed patients were admitted to the study. Sepsis was considered present if patients had spiking temperatures and leucocytosis and if a septic focus could be demonstrated. Blood cultures were positive in most. cases. Stress was considered present in patients who had suffered multiple trauma, or severe nonseptic pancreatitis, or had undergone operation for a ruptured abdominal aortic aneurysm.

\section{Severity of disease}

The severity of sepsis and stress was estimated using two methods. The Bistrian catabolic index score estimates metabolic stress based upon 24 hour urine urea nitrogen excretion (Bistrian 1979). Severity of sepsis was graded using the system proposed by Elebute and Stoner (Elebute 1983) scoring local and secundary effects of sepsis, pyrexia and laboratory data.

\section{Solutions}

Patients were randomized to receive TPN with a standard or a branched-chain amino acid-enriched amino acid/glucose mixture. Both regimens were isocaloric and isonitrogenous containing $5 \mathrm{~g}$ amino acid nitrogen $/ 1$. The standard solution contained $15.6 \%$ BCAA, the enriched solution $50.2 \%$ BCAA of total nitrogen (Table 2.1). The amino acid-glucose mixture contained $20 \%$ glucose. Five hun- 
dred $\mathrm{ml}$ of a $10 \%$ fat emulsion was given at least twice a week and infused over a 24 hour period. Mineral contents of both solutions were adjusted to patients needs. Trace elements and vitamin contents of either solution were equal (Table $6.1)$.

Table 6.1 Nutrition characteristics

\begin{tabular}{lll}
\hline & $\begin{array}{l}\text { BCAA }(\mathrm{n}=49) \\
(\overline{\mathrm{x}} \pm \mathrm{sd})\end{array}$ & $\begin{array}{l}\text { Standard }(\mathrm{n}=52) \\
(\overline{\mathrm{x}} \pm \mathrm{sd})\end{array}$ \\
\hline $\mathrm{NPE}(\mathrm{kCal} / \mathrm{g} \mathrm{N})$ & $205 \pm 33$ & $214 \pm 28$ \\
$\mathrm{NPE}(\mathrm{kCal} / \mathrm{kg})$ & $33 \pm \rrbracket 1$ & $34 \pm 9$ \\
$\mathrm{AA}(\mathrm{g} / \mathrm{kg})$ & $0.17 \pm 0.05$ & $0.17 \pm 0.04$ \\
$\mathrm{BCAA}(\mathrm{g} \mathrm{N} / \mathrm{kg})$ & 0.09 & 0.03 \\
Percentage fat $(\%)$ & $13 \pm 9$ & $16 \pm 8$ \\
\hline
\end{tabular}

\section{Biochemical data}

During the seven-day study period blood samples were drawn on day 0,4 and 7 for determination of plasma amino acid concentrations. For this determination 1.0 $\mathrm{ml}$ of plasma was deproteinized by addition of $40 \mathrm{mg}$ sulfosalicylic acid. After protein precipitation samples were centrifuged $\left(3.000 \times \mathrm{g}, 10 \mathrm{~min}, 4^{\circ} \mathrm{C}\right)$ and the supernatants were passed through a millipore filter $(0.22 \mu \mathrm{m}$ pore size) before storage at $-70^{\circ} \mathrm{C}$ until analysis. Amino acids were determined on $30 \mu \mathrm{l}$ of each sample by a LKB 4400 automated amino acid analyzer, employing Lithium buffers and ninhydrin detection (Andrews 1987). Amino acid concentrations are reported as $\mu \mathrm{mol} / \mathrm{l}$ of plasma.

Parallel with the study control values of plasma amino acids were obtained 1 hr after an average Dutch breakfast from 30 healthy volunteers, 14 males and 16 females, mean age 31.4 years (range 19-52). The meal contained on average 275 $\mathrm{kCal}, 8.8 \mathrm{~g}$ protein, and 38 energy percent fat.

\section{Statistical considerations}

Results are evaluated using one way ANOVA's. To determine which pairs of groups were significantly different Scheffe's post hoc t-test was performed. 


\section{RESULTS}

\section{Patients}

Most patients needed treatment in a surgical intensive care setting. Fourty-nine patients received the BCAA-enriched solution and 52 patients the standard amino acid solution. Both groups are comparable for age and sex as well as for sepsis scores and catabolic indices on day 0 (Table 6.2).

Table 6.2 Study population $(n=101)$

\begin{tabular}{llll}
\hline & & $\begin{array}{l}\text { BCAA }(\mathrm{n}=49) \\
(\overline{\mathrm{x}} \pm \operatorname{sem})\end{array}$ & $\begin{array}{l}\text { Standard }(\mathrm{n}=52) \\
(\overline{\mathrm{x}} \pm \mathrm{sem})\end{array}$ \\
\hline Sex & Female & 21 & 25 \\
& Male & 28 & 27 \\
Age (yrs) & $56 \pm 2$ & $58 \pm 2$ \\
Elebute and Stoner sepsis score on day 0 & $11.1 \pm 0.8$ & $10.9 \pm 0.9$ \\
Bistrian metabolic score on day 0 & $10.3 \pm 1.3$ & $9.8 \pm 1.0$ \\
\hline
\end{tabular}

\section{Plasma amino acids}

On day 0 a 1 -way ANOVA indicates that concentrations of virtually all amino acids in both groups are significantly decreased compared to post prandial control values. Methionine levels are normal while phenylalanine concentrations are elevated. Post hoc t-tests indicate significant differences between the control group and either standard or BCAA-enriched group for all amino acids, except for glycine and ornithine, where differences are significant only between control and standard groups (Table 6.3). No differences exist between the standard group and the BCAA-enriched group.

On day 4 the 1-way ANOVA indicates significant differences between groups for all amino acids, except for ornithine where levels normalized. Post hoc t-tests indicate plasma valine, isoleucine and leucine levels to be significantly increased in the BCAA group compared to both the standard and control group. Plasma levels of these amino acids in the standard group are significantly lower than those in the post prandial control patients. In addition, threonine, lysine, glutamine, alanine, tyrosine, histidine and arginine levels are significantly lower and phenylalanine significantly higher in either study group if compared to those in the control group, with no differences between the studygroups. Glycine levels in the 


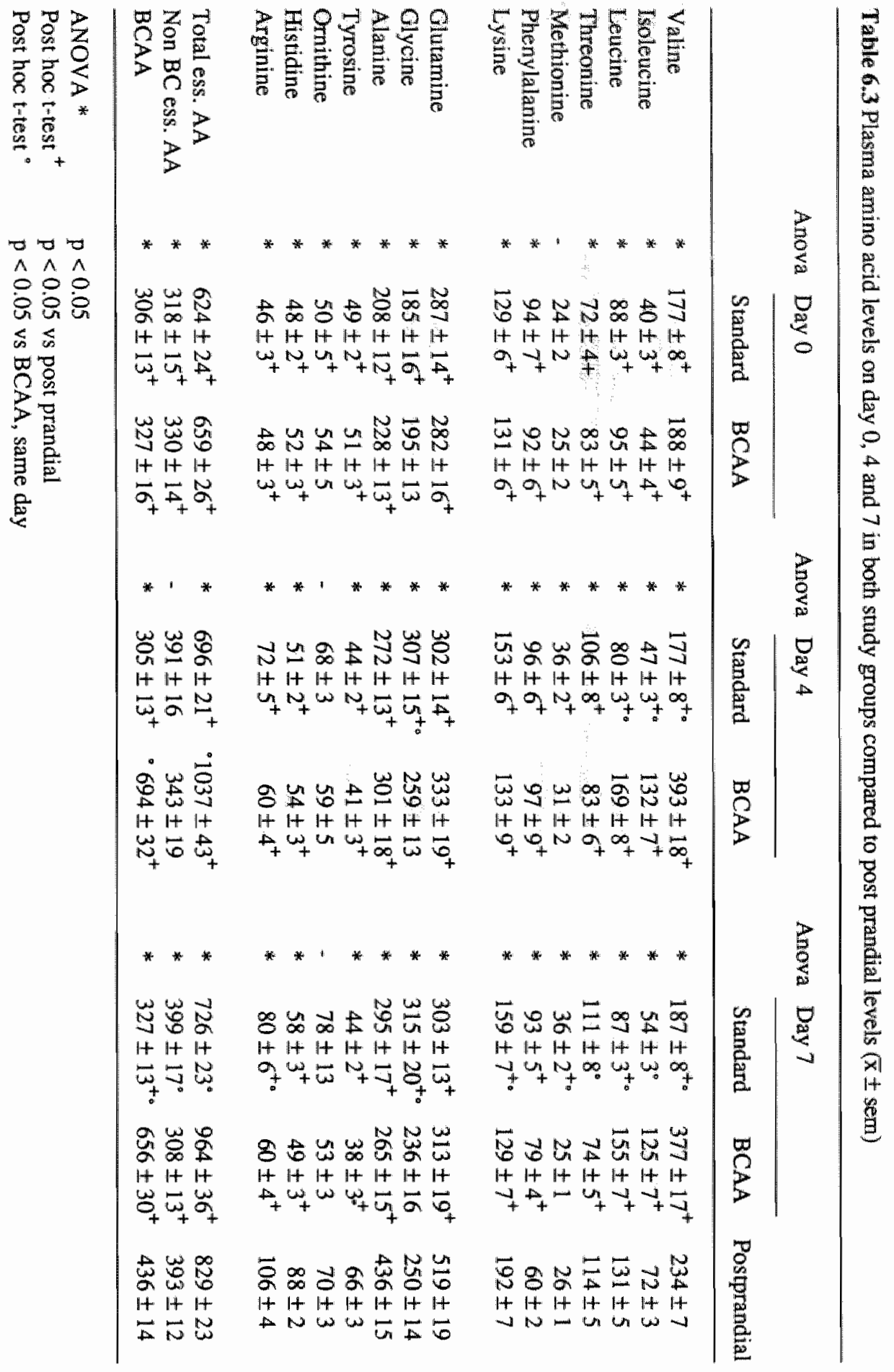



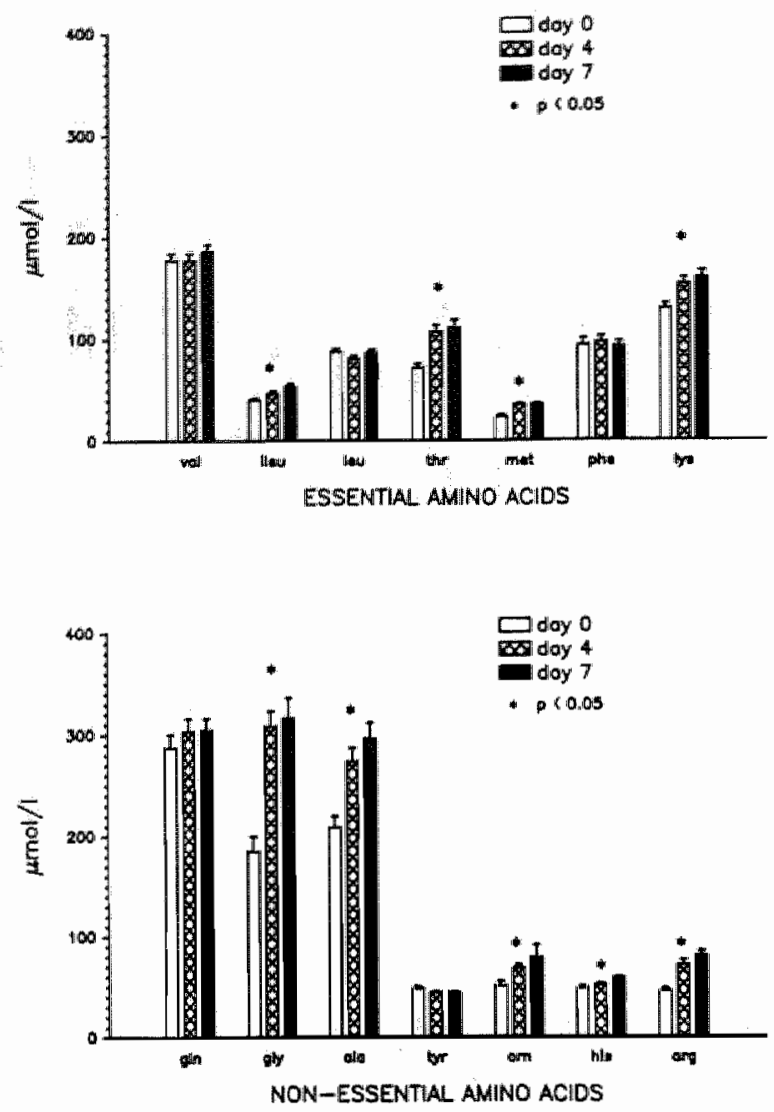

Figure 6.1 The infusion of a ballanced standard amino acid formulation containing TPN solution induces a consistent and significant rise of most amino acid concentrations ( ${ }^{*}$ ANOVA $p<0.05$ ).

standard group are significantly elevated if compared to both the BCAA and control group, with no differences between these last two groups. Methionine levels in the standard group are significantly elevated compared to the control group (Table 6.3).

Virtually the same amino acid profile is present on day 7. The 1-way ANOVA indicates significant differences present between groups for all amino acids, again with the exception of ornithine. Post hoc t-tests indicate that isoleucine and threonine concentrations in the standard group are not significantly lower com- 

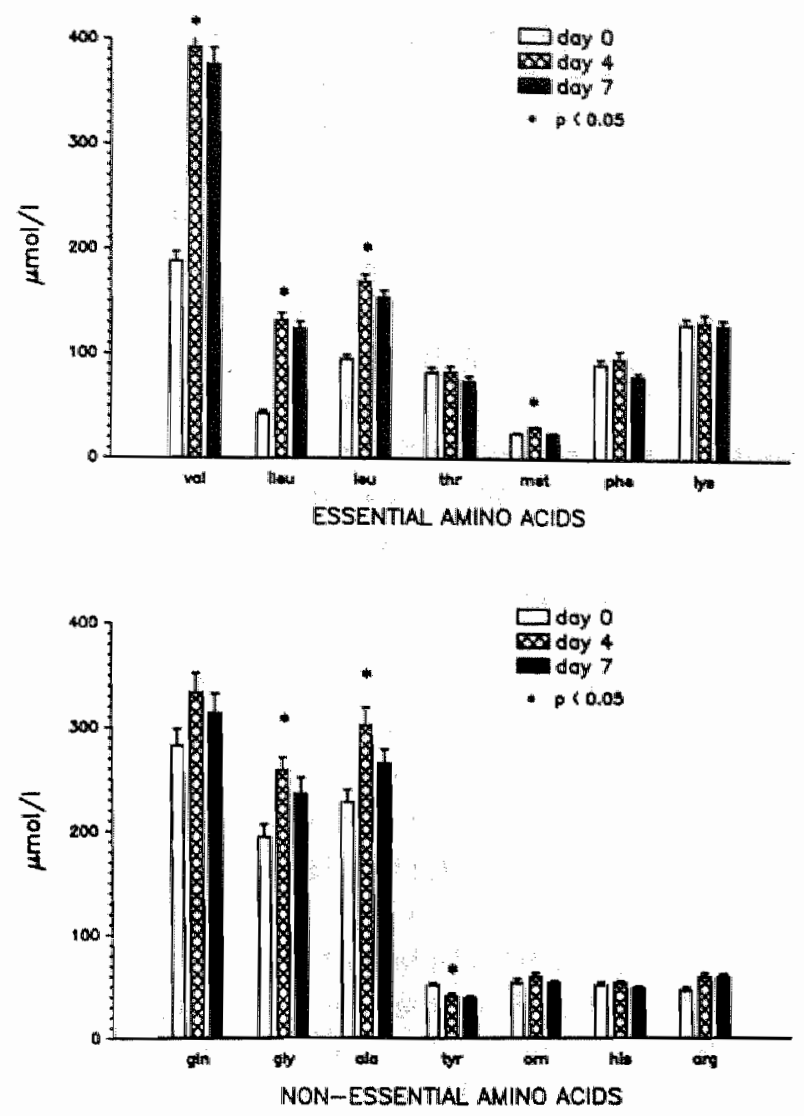

Figure 6.2 Infusions of a branched-chain amino acid entiched formulation containing TPN solution induces apart from increased BCAA concentrations, elevated glycine, alanine and arginine levels, while tyrosine concentrations decrease. Most initial amino acid concentration elevations on day 4 turn into a decrease by day 7 (* ANOVA p<0.05).

pared to the post prandial group. Methionine levels in the standard group become significantly elevated compared to both the BCAA and the post prandial group. No further changes occur compared to the day 4 pattern (Table 6.3).

Most amino acid concentrations rise during infusion of the standard solution. A 1-way ANOVA indicates that this rise is significant for isoleucine, threonine, methionine, lysine, glycine, alanine, omithine, histidine and arginine. Post hoc 
$t$-tests indicate that for most of these amino acids a significant increment is already reached on day 4 and maintained on day 7 . Increments of isoleucine, ornithine and histidine reach significance only by day 7 (Fig. 6.1).

In contrast to the standard group changes in plasma amino acid concentrations in the BCAA group do not show a consistent pattem; most amino acid concentrations rise first but decrease subsequently. A tremendous increase of the plasma valine, leucine and isoleucine levels is observed on days 4 and 7. Methionine, glycine and alanine concentrations increase but tyrosine levels significantly decrease across days, Post hoc t-tests indicate a significant rise present on day 4 and maintained on day 7 only for the BCAA, while tyrosine levels are decreased on day 4 and remain so on day 7 . Methionine, glycine and alanine levels decrease after an initially significant rise on day 4 (Fig. 6.2).

The sum of essential amino acids is not different between the trial groups on day 0 but both groups display significantly lower levels than those in the post prandial group. Once the infusion was started, the sum of essential amino acid concentrations increases significantly in the BCAA infused group on day 4 , exclusively due to the increment of the branched-chain amino acids. The sum of essential amino acids rises slower in the standard group due to a lower rise in the sum of BCAA. This significant rise of the sum of essential amino acids in the BCAA group is still present on day 7 if compared to both the standard and post prandial groups. Again this rise is solely due to the increased BCAA levels. However, the non branched-chain essential amino acids display significantly lower values in the BCAA group compared to the standard and post prandial group. In contrast to the BCAA group total essential amino acid concentrations, and non branched-chain essential amino acids in the standard group reach post prandial levels on day 7 , only BCAA levels remain at a significantly lower level (Table 6.3). 


\section{DISCUSSION}

Plasma amino acid levels during sepsis and stress are most often reported to be lowered (Clowes 1980, Stinnett 1982), although increased values have also been reported (Freund $1978^{\mathrm{b}}$, Woolf 1977 ). These varying findings may be the result of differences in the clinical conditions of the patients investigated or in differences in the study conditions.

It has been suggested that the rate of BCAA oxidation determines the rate of overall protein catabolism (Odessey 1974). The increased BCAA oxidation would be necessary to provide for intracellular energy deficits that are thought to be the result of reduced glucose oxidation (O'Donnel 1976). Low plasma BCAA concentrations would thus be the result of the increased BCAA consumption (Wannemacher 1977, Freund 1979, Clowes 1980).

It should be emphasized that virtually all attempts to explain sepsis induced amino acid metabolism alterations are based on observations in plasma amino acid concentrations. The inconsistency in these observations are in contrast to the more recent reports on changes in intracellular amino acid levels that occur in trauma or sepsis. These reports provide consistent data indicating increments of the neutral amino acids, decrements of the basic amino acids and glutamine and

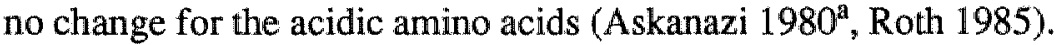

The steep elevations of intracellular BCAA concentrations in contrast to low or virtually unchanged plasma BCAA concentrations can be explained in several ways. They may reflect impaired intracellular BCAA degradation, or may result from impaired efflux from the cell in trauma and sepsis (Odessey 1974, Askanazi $1980^{\mathrm{b}}$ ). In addition, BCAA may be used as a nitrogen source for pyruvate to form. alanine (Askanazi 1980 ${ }^{\mathrm{a}}$ ). Low plasma BCAA levels have furthermore been thought to result from their ability to furnish fuel during sepsis and trauma. The preferential use of lipids (Carpentier 1979, Askanazi $1980^{\circ}$ ) for energy supply and the abundance, rather than shortage, of BCAA in trauma or sepsis are in contradistinction with this view.

The stimulatory effect of BCAA on protein synthesis is still under debate (Brennan 1986) and may not provide an explanation for the (relatively) low plasma concentrations of these amino acids. It seems, therefore, as if altered cell-membrane kinetics (Askanazi 1980 ${ }^{\mathrm{a}}$ ) and impaired degradation rather than changes in protein or energy metabolism dictate the observed changes in the intracellular and plasma levels of the BCAA.

The results of the current study, in which no intracellular amino acid concentrations were determined indicate that infusion of a BCAA enriched standard TPN solution results in a distortion of the plasma amino acid profile, compared to control groups. A discussion about potential effects of these plasma AA profile 
distortions on protein metabolism will not reach further than comparing hypotheses. It should be kept in mind, however, that plasma amino acid distortions resulting from extreme diet variations can result in impaired growth and abnormal behavior (Rose 1981) and altered protein metabolism (van Berlo 1989).

We conclude that enrichment of standard amino acid solutions with branchedchain amino acids does not result in consistently rising amino acid levels, but rather in significantly lower plasma concentrations of non-BCAA essential amino acids. This leaves the use of BCAA enriched solutions questionable, and supports the conclusion by others that benefits must be demonstrated more convincingly in man before a wide spread use of such solutions can be advocated (Brennan 1986). 


\section{REFERENCES}

Andrews R. LKB protein chemistry notes (14). LKB Biochrom Ltd, Cambridge, U.K. 1987. Askanazi J, Carpentier Y, Michelsen C, Elwyn D, Furst P, Kantrowitz L, Gump F, Kinney J. Muscle and plasma amino acids following injury, influence of intercurrent infection. Amnals of Surgery $192: 78-85.1980^{\mathrm{a}}$.

Askanazi $J$, Furst $P$, Michelsen $C B$. Muscle and plasma amino acids after injury: Hypocaloric glucose $\psi_{s}$ amino acids infusion. Annals of Surgery 191:465-469,1980

Askanazi J, Carpentier YA, Elwyn DH. Influence of total parenteral nutrition on fuel utilization in injury and infection. Annals of Surgery 191:40-46,1980 ${ }^{\circ}$.

Berlo wan CLH, Bogaard van den AEJM, Heijden van der MAH. Is increased ammonia liberation after bleeding in the digestive tract the consequence of complete absence of isoleucine in hemoglobin? A study in pigs. Hepatology 10:315-323,1989.

Bistrian B. A simple technique to estimate severity of stress. Surgery, Gynecology and Obstetrics 148:675-678,1979.

Brennan MF, Cerra F, Daly JM et al. Report of a research workshop: branched-chain amino acids in stress and injury. Jourmal of Parenteral and Enteral Nutrition 10:446-452, 1986.

Carpentier YA, Askanazi J, Elwyn DH. Effects of hypercaloric glucose infusion on lipid metabolism in injury and sepsis. Journal of Trauma 19:649-654,1979.

Clowes G, O'Donnel T, Blackbum G, Maki T. Energy metabolism and proteolysis in traumatized and septic man. Surgical Clinics of North America 56:1169-1184,1976.

Clowes $\mathrm{G}$, Randall $\mathrm{H}$, Cha $\mathrm{C}$. Amino acid and energy metabolism in septic and traumatized patients. Journal of Parenteral and Enteral Nutrition 4:195-205,1980.

Elebute E, Stoner H. The grading of sepsis. British Journal of Surgery 70:29-31,1983.

Fischer J, Rosen H, Ebeid H, James J, Keane J, Soeters P. The effect of nomalisation of plasma amino acids on hepatic encephalopathy in man. Surgery 80:77-91,1976.

Freund $\mathrm{H}$, Yoshimura $\mathrm{N}$, Lunetta $\mathrm{L}$, Fischer $\mathrm{J}$. The role of the branched-chain amino acids in decreasing muscle catabolism in vivo. Surgery 83:611-618,1978 "

Freund $\mathrm{H}, \mathrm{R}$ yan $\mathrm{J}$, Fischer $\mathrm{J}$. Amino acid derangements in patients with sepsis: treatment with branched-chain amino acid rich infusions. Ammals of Surgery 188:423-428,1978 ${ }^{\mathrm{b}}$.

Freund $\mathrm{H}$, Atamian I, Holroyde J, Fischer J. Plasma amino acids as predictors of the severity and outcome of sepsis Annals of Surgery 190:571-576,1979.

Mizock B. Branched-chain amino acids in sepsis and hepatic failure. Archives of Internal Medicine 145:1284-1288,1985.

O'Donnel TF, Clowes GHA, Blackbum GL er al. Proteolysis associated with a deficit of peripheral energy fuel substrates in septic man. Surgery 80:192-200,1976.

Odessey $R$, Khairallah $\mathrm{E}$, Goldberg A. Origin and possible significance of alanine production by skeletal muscle. Journal of Biological Chemistry 249:7623-7629,1974.

Rose WC. Feeding experiments with mixtures of highly purified amino acids. Journal of Biological Chemistry 74:155-161,1931.

Roth E, Zoch G, Schultz F, Karner J, Muhlbacher F, Hamilton G, Mauritz W, Sporn P, Funovics J. Amino acid concentrations in plasma and skeletal muscle of patients with acute hemorrhagic necrotizing pancreatitis. Clinical Chemistry 31:1305-1309,1985.

Stinnett $J$, Alexander J, Watanabe $\mathrm{C}$ et al. Plasma and skeletal muscle amino acids following severe burn injury in patients and experimental animals. Annals of Surgery 195:75-89,1982. 
Wannemacher R. Key role of various individual amino acids in host response to infection. Americal Journal of Clinical Nutrition 30:1269-1280,1977.

Woolf LI, Groves AC, Moore JP. Arterial plasma amino acids in host response to infection. American Journal of Clinical Nutrition 30:1269-1271,1977. 


\section{Morbidity and mortality in sepsis and stress: the Elebute and Stoner sepsis gradation related to morbidity parameters}

\section{SUMMARY}

The grading of illness facilitates monitoring of its course and evaluation of the effect of treatment. Several systems have been developed to achieve this goal. In the current study we investigated the value of the Elebute and Stoner (ES) sepsis scores to predict mortality in a septic $(n=56)$ and a non-septic, metabolically stressed $(n=45)$ patient group. We further investigated whether the addition of a morbidity parameter would improve the prediction of outcome derived from the ES score. Morbidity was assessed by scoring four key organ systems and calculated by squaring the values of the three organ systems with the most severely disrupted functions.

The results indicated a good correlation between the Elebute and Stoner sepsis grading on day 0 and morbidity, expressed as disruption of organ function. In the group of sepsis patients mortality was significantly related to elevations of the ES sepsis scores, while in the group of metabolically stressed patients the mortality percentages in low and moderate ES sepsis score groups were relatively high. We confirm that the Elebute and Stoner sepsis grading is suitable to categorize patients with sepsis of thoraco-abdominal origin and to predict mortality. We furthermore conclude that this system is as adequate to assess morbidity and predict mortality in non-septic, metabolically stressed patients. The addition of a morbidity parameter further improves the prediction of outcome by the ES score. 


\section{INTRODUCTION}

In the last decade the awareness of the necessity to quantify the severity of sepsis and non-septic metabolic stress has increased. The grading of illness creates the possibility to monitor the course of that illness and to evaluate the effect of treatment (Dionigi 1986).

To achieve this goal several classification systems have been introduced. Knaus developed the APACHE score (Acute Physiology And Chronic Health Evaluation). His method employs pre-admission health status indicators and 34 physiologic variables (Knaus 1981). The original method was later simplified to APACHE II employing fewer wariables (Knaus 1985). More recently, the same group proposed an extension of the APACHE II system to improve its validity and reproducibility and to test the system for health policy purposes (Wagner 1989). These scoring systems, however, require an intensive care unit (ICU) setting. Stevens developed a "sepsis severity score" (Stevens 1983). The severity of a septic proces was scored, based on deteriorated functions in seven key organ systems of the body. Meakins proposed a classification that incorporates ten anatomic compartments of established intra-abdominal infection with the APACHE score of Knaus (Knaus 1981, Meakins 1984). This binomial classification provides a technique to evaluate patient groups uniformly in the study of effectiveness of new treatment approaches of intra-abdominal infections. Because this scoring system is restricted to the abdomen and because the applied etiologic classifications of intra-abdominal infections are manifold, large patient groups are required in such studies.

Elebute and Stoner graded sepsis by scoring the attributes of sepsis under four headings: local effects and secundary effects of sepsis, pyrexia and laboratory data (Elebute 1983). This simple system produces a number indicating the severity of sepsis that varies with the condition of the patient. Although the authors described this scoring system originally in a small patient group, they believed that it was appropriate for use in sepsis of any origin.

In the present study we employed the Elebute and Stoner sepsis score not only in patients with sepsis, but also in patients with non-septic metabolic stress. We evaluated the predictive value of this sepsis score with regard to mortality in both groups of patients. In addition, we evaluated the relation of this sepsis score with parameters describing organ dysfunction, and the potential of organ function parameters to further improve the predictive value of ES scores. 


\section{Patients}

Patients with sepsis or trauma above 18 years of age were eligible for this study. Sepsis was considered present when a combination of some of the following criteria was present: spiking body temperature, hyperventilation, tachycardia, leucocytosis, decreased blood pressure and diminished urine output. A clinically manifest septic focus was considered obligatory. Non-septic metabolic stress was considered present when patients suffered from a multitrauma, underwent an operation for a ruptured abdominal aortic aneurysm or suffered from acute non septic pancreatitis.

\section{Sepsis scores}

Severity of sepsis was scored according to the method of Elebute and Stoner that considers local and secondary effects of sepsis, pyrexia and laboratory data (table 2.4). This system produces a number that indicates the severity of sepsis. Mild sepsis or metabolic stress was considered present if patients displayed a score below 10 (low ES), moderate sepsis or metabolic stress if the score was 10 or higher but below 20 (mod ES), and severe sepsis or metabolic stress if the score was 20 or more (high ES).

\section{Morbidity scores}

Morbidity was assessed by scoring the functioning of four organ systems. Respiratory, circulatory and renal function were scored employing a scale from 1 to 5 indicating an increasing organ function disturbance. Bilirubin levels were evaluated in a similar way (table 2.3). Similar to Stevens who scored seven key organs and calculated a score by squaring the assigned values given to each of the three organ systems with the most severe dysfunction, we calculated a score by adding the squared values of the three most severely disrupted organ functions. Low organ function (OF) scores were values below or equal to 25 , moderate OF scores values over 25 , but below 40 and high OF scores values equal to or over 40 .

The study lasted seven days. Both sepsis scores and organ function parameters were determined on days 0 and 7 .

\section{Mortality}

Mortality was recorded as sepsis or not sepsis related.

\section{Statistical considerations}

Statistical evaluation was performed using one-way ANOVA's and Scheffe's test for multiple ranges. 


\section{RESULTS}

Hundred-and-one patients were included in the study, 56 patients were septic and 45 patients suffered from non-septic metabolic stress. Most of the patients required treatment in the ICU. The diagnoses of these patients are listed in table 7.1. Table 7.2 shows the Elebute/Stoner scores on day 0 for the sepsis and metabolic stress groups. In the sepsis-group 37 patients (66\%) had moderate ES scoring values, while in the metabolic stress group 34 patients (75\%) had low ES scoring values. Organ function scores showed a similar distribution, although a wider variation of these values prohibited differences between groups becoming significant. This may illustrate that organ function scores reflect another aspect of

Table 7.1 Diagnoses of the total study group $(n=101)$

Perforated viscera (anastomotic leakage etc.)

Pancreatitis

Enterocolitis (radiation, Crohn, ulcerative colitis, ischemia) 13

Intra-abdominall absces

Multiple infections

Ruptured abdominal aortic aneurysm

Other (polytrauma, tetanus,etc.)

Table 7.2 Elebute and Stoner scores on day 0 and related organ dysfunction scores of patients with sepsis and non-septic metabolic stress. (mean $\pm \mathrm{sd}$ )

\begin{tabular}{lll}
\hline & $\begin{array}{l}\text { Sepsis } \\
(n=56)\end{array}$ & $\begin{array}{l}\text { Metabolic stress } \\
(n=45)\end{array}$ \\
\hline $\begin{array}{lll}\text { Elebute/Stoner Low }(<10) \text { day } 0 \\
\text { Related organ dysfunction score }\end{array}$ & $\begin{array}{l}7.1 \pm 1.9(n=13) \\
18.1 \pm 16.0\end{array}$ & $\begin{array}{l}5.6 \pm 2.3(n=34) \\
17.1 \pm 11.4\end{array}$ \\
Elebute/Stoner Moderate $(\geq 10,<20)$ day 0 & $13.9 \pm 2.8^{*}(n=37)$ & $12.9 \pm 2.3^{*}(n=8)$ \\
Related organ dysfunction score & $27.8 \pm 15.5$ & $30.9 \pm 14.9^{*}$ \\
Elebute/Stoner High $(\geq 20)$ day 0 & $23.5 \pm 3.3^{*^{*}}(\mathrm{n}=6)$ & $23.7 \pm 4.0^{+*}(\mathrm{n}=3)$ \\
Related organ dysfunction score & $44.0 \pm 8.9^{*}$ & $45.0 \pm 4.4^{*}$ \\
\hline
\end{tabular}

* p<0.05 vs Low ES; ${ }^{+}$p<0.05 vs Mod ES 


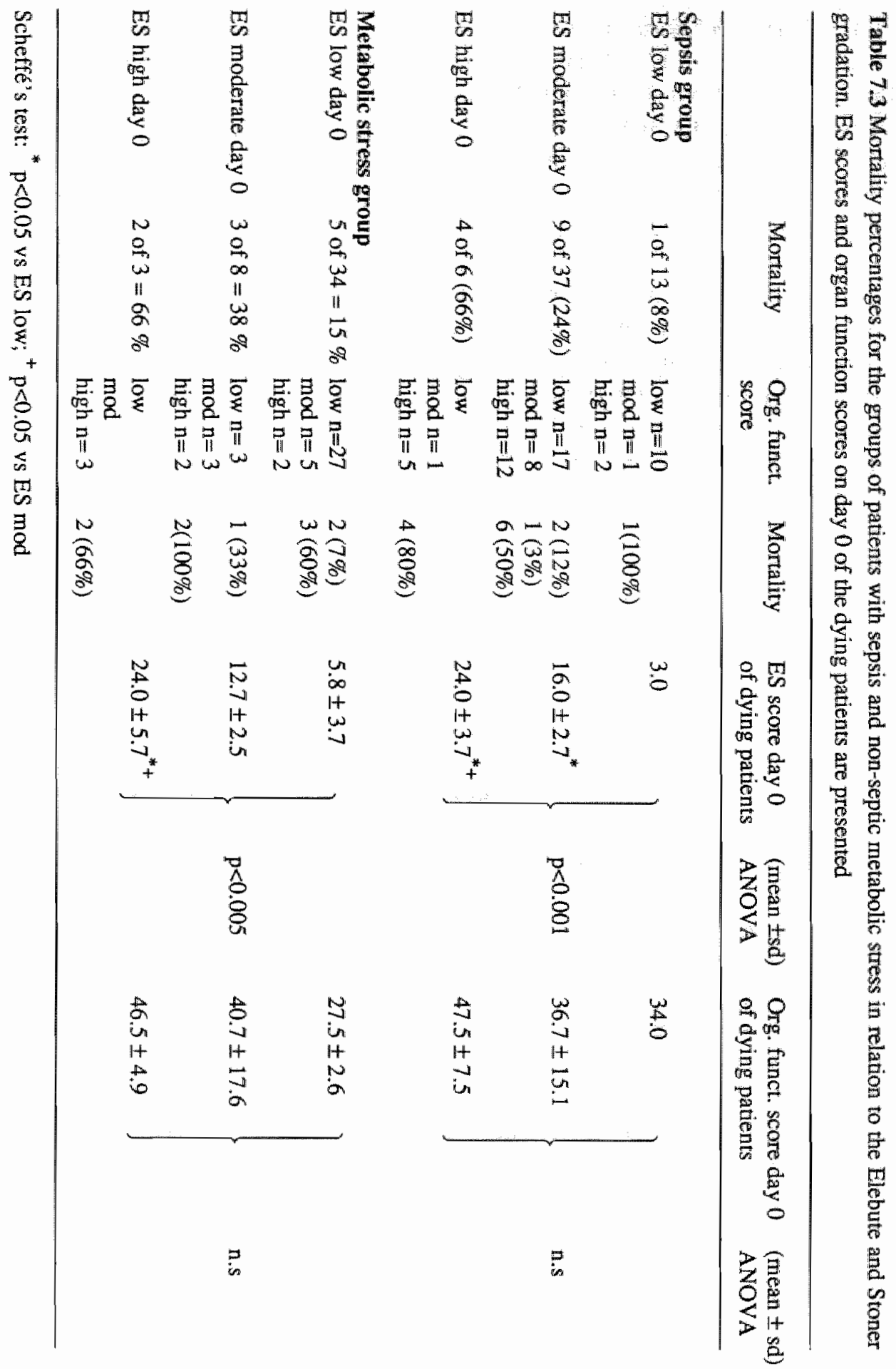


disease. This observation is corroborated by the relatively poor, albeit significant correlations between ES sepsis scores and organ function scores on day 0: sepsis group $0.52(p<0.001)$ and metabolic stress group $0.59(p<0.001)$.

The relation of the Elebute / Stoner sepsis grading with mortality is shown in table 7.3; increasing sepsis scores on day 0 were associated with significantly increasing mortality in both the sepsis and metabolic stress groups. Mortality in the metabolic stress group with low and moderate ES scores was higher than in the sepsis group. Mortality percentages in the high ES score groups in sepsis and metabolic stress groups were similar. Adding the evaluation of organ function scores improved the prediction of outcome in both study groups: a discrepancy between organ function scores on day 0 and ES scores on day 0 resulted in a positive or negative adjustment of the original ES score associated mortality. Furthermore, ES sepsis scores on day 0 of patients dying in multiple organ failure were significantly different, whereas organ function scores on day 0 of these patients were high and not different between low, moderate and high ES sepsis gradation groups in either study group.

\section{DISCUSSION}

Classification of the severity of illness may be advantageous in predicting morbidity and mortality. The ultimate goal is to provide information that will be used to make treatment decisions for individual patients (Knaus 1989). Thus, patients with a low risk profile that do not need intensive treatment should be identified and served with monitoring rather than admitted for intensive treatment. Scoring systems providing such information should be easily applicable. The grading of ilness as proposed by Elebute and Stoner is considered a simple but sensitive method that was originally designed for the classification of thoraco abdominal sepsis (Elebute 1983).

In the current study we tried to establish whether the ES scoring system was also applicable in patients suffering from metabolic stress. We found a significant correlation between the Elebute and Stoner sepsis score and outcome in non septic metabolically stressed patients.

We conclude that the Elebute and Stoner score estimated disease severity in patients with non-septic metabolic stress with a similar accuracy as in septic patients. Mortality was related to the initial ES score. Overall mortality rate in patients with ES scores equal or greater than 20 in the current study was $66 \%$. This concurs with the original findings of Elebute and Stoner, who found an $80 \%$ mortality rate in patients with scores greater than 19 (Elebute 1983). Dominioni et al. reported mortality to be greater than $70 \%$ in patients with sepsis scores over 
20 (Dominioni 1987). In addition, we found that the scoring of the functioning of organ systems improved the predictive value of $\mathbb{E S}$ scoring in relation to mortality. Thus, if the organ functioning score was in a higher category than the ES score, the predicted mortality rate had to be adjusted upward and, if it was in a lower category, a downward adjustment had to be made. However, not all cells were filled with sufficient numbers of patients. This warrants a careful interpretation of these data. A larger follow-up study should provide further suppport.

The results of our study may support decision making with regard to providing or denying ICU treatment to a critically ill patient. Such a decision is complex and difficult, and may be enhanced by information. It is unlikely that any system will ever provide information of such accuracy that it can completely replace clinical judgement. We found the Elebute and Stoner sepsis grading a simple method to categorize patients with sepsis of thoraco abdominal origin and to predict mortality. We found the system also applicable to grade patients with non-septic metabolic stress. Adding an organ function score further improved the predictive value of ES scores, in both septic and non-septic metabolically stressed patients. We therefore consider the ES score and organ functioning score a valuable support in the proces of deciding whether a patient should, or should not receive ICU treatment. 


\section{REFERENCES}

Dionigi $R$, Cremaschi $R$, Jemos $V$, et al. Nutritional assessment and severity of illness classification systems: a critical review on their clinical relevance. World J Surg 10:211,1986 .

Dominioni L, Dionigi $\mathrm{R}$, Zanello $\mathrm{M}$, et al. Sepsis score and acute-phase protein respons as predictors of outcome in septic surgical patients. Arch Surg 122:141-146,1987.

Elebute E, Stoner H. The grading of sepsis. Br I Surg 70:29-31,1983.

Knaus W, Zimmerman J, Wagner D, et al. APACHE-acute physiology and chronic health evaluation: a physiologically based classification system. Crit Care Med 9:591-597,1981.

Knaus W, Draper E, Wagner D, Zimmerman J. APACHE II: a severity of disease classification system. Crit Care Med 13:818-829,1985.

Knaus W, Wagner D. Individual patient decisions. Crit Care Med 17:S204-S209, 1989.

Meakins $\mathrm{J}_{*}$ Solomkin $\mathrm{J}$, Allo $\mathrm{M}$, et al. A proposed classification of intra-abdominal infections. Arch Surg 119:1372-1378,1984.

Stevens L. Gauging the severity of surgical sepsis. Arch Surg 118:1190-1192,1983.

Wagner D, Draper E, Knaus W. Development of APACHE III. Crit Care Med 17:S199S203,1989. 


\section{Chapter 8}

\section{General conclusion}

This study suffers from problems that are often inherent to large clinical studies:

1. variable population

2. assessment of the influence of one of many factors determining outcome. Nutritional support of any kind can at best only modulate outcome in severely ill patients that are otherwise adequately treated by primary measures.

These factors make it difficult to assess the effects of different nutritional regimens on morbidity and mortality. Therefore metabolic endpoints were studied too like the nitrogen balance which by itself can be difficult to assess.

Patients were stratified for the presence of sepsis or metabolic stress and then randomized to receive a $\mathrm{BCAA-enriched} \mathrm{or} \mathrm{a} \mathrm{standard} \mathrm{amino} \mathrm{acid} \mathrm{solution.} \mathrm{The}$ solutions were isocaloric and isonitrogenous. A major criticism may be that if an isonitrogenous BCAA-enriched solution is administered, this group of patients will receive less of the other essential amino acids. This could be prevented by giving the amount of conventional amino acids and give in addition extra BCAA to one group. Another criticism, however, could then arise, pointing out that the potential benefit in the group receiving the BCAA-enriched solution is the result of amino acid nitrogen enrichment and not of the BCAA enrichment. This problem could be solved by including a group of patients receiving extra amino acid nitrogen of a conventional composition. The result of all this would be that a study would need to include 4 or even more study arms. All this would lead to studies that would need too many patients becoming unfeasible to carry out. We therefore chose to include only two groups of about 50 patients receiving isocaloric isonitrogenous amounts of either BCAA-enriched or conventional amino acid solutions. 
In this study no significant differences in morbidity and mortality were found. However, significant differences were observed for blood cells (band-shaped neutrophils) and proteins. These findings could be accidental if the patient population of both groups would be different. Considering the diagnoses of the patients in both study groups, however, this is unlikely. This is confirmed by the fact that no differences are found between groups on day 0 of the study when sepsis scores (Elebute and Stoner) and metabolic stress scores (Bistrian) are considered. If we assume that these differences are not accidental, then it seems as if a solution with a conventional amino acid composition improves host resistance against sepsis better than BCAA enrichment of the amino acid solution.

A potential explanation might be that enrichment of the amino acid solution with BCAA results in an imbalanced pattern of the plasma amino acids. Indeed we found significantly lower plasma concentrations of the non-BCAA essential amino acids in the group of patients receiving the BCAA-enriched solution. This supports but does not prove the above mentioned improved host resistance in the conventional amino acid regimen. There are no indications in the literature that such slight decreases in levels of essential amino acids are instrumental to these observations.

The results of the present study allow the following conclusions with regard to the use of BCAA-enriched solutions in patients with sepsis and/or stress:

- BCAA-enrichment does not lead to an improvement of nitrogen balances in the total patient population. However, the subgroup of moderately stressed patients showed a marginally significant improvement of the cumulative nitrogen balance.

- the conventional regimen improves some plasma protein parameters and cell numbers more than the BCAA-enriched solution

- no differences in morbidity and mortality between the two study groups are found.

This study therefore does not support the use of enrichment of the amino acid solution with branched-chain amino acids in total parenteral nutrition in patients with sepsis and/or stress. 


\section{Summary}

An introduction to the subject of this thesis is given in chapter 1. Sepsis and metabolic stress are characterized by a loss of total body protein, an increased gluconeogenesis and ongoing lipolysis, the latter presumably to provide for the increased energy demands that exist under these circumstances. The loss of total body protein occurs because of a disproprotionately increased proteolysis compared to protein synthesis taking place in sepsis and trauma. The BCAA valine, leucine and isoleucine are essential amino acids with the unique feature that they can be completely oxidized in muscle and that the degradation capacity in liver tissue is limited for these amino acids. They are therefore considered a potential energy source for muscle tissue. In-vitro experiments suggested furthermore that the BCAA have protein sparing properties. While all three BCAA stimulate protein synthesis, leucine and especially alpha-keto-isocaproic acid inhibit proteolysis. Animal experiments suggested that administration of BCAA enriched amino acid solutions improved the nitrogen-sparing effect of standard amino acid solutions in a dose related manner. Thus, some studies reported increased muscular and hepatic protein synthesis while other studies observed a decreasing 3-methylhistidine excretion in urine, or decreasing arterio-venous differences in amino acid concentrations, indicating decreasing proteolysis. Some studies have suggested that the use in clinical settings of amino acid solutions enriched with BCAA induces a significant improvement of nitrogen balances compared to standard amino acid solutions. However, other studies do not confirm these findings. Similar controversies are present with regard to the claim that immune function parameters improve and short tum-over proteins increase as a result of the use of BCAA enriched TPN solutions. The effects of BCAA enrichment on morbidity and mortality have not been reported.

In chapter 2 purpose, patients and methods of the study presented in this thesis are described. The primary goal of the study was to investigate whether the administration of a BCAA-enriched TPN solution induces an improvement of the nitrogen balance compared to TPN with a standard amino acid solution. Secondary goals were to investigate whether clinical outcome would improve as a result of BCAA administration, to analyse plasma amino acid profiles, to analyse the effects of infusion of amino acid solutions on plasma amino acid patterns, to 
analyse bloodcells and plasma protein, and to evaluate scoring systems of sepsis and morbidity. Patients were stratified for sepsis or metabolic stress and trauma. Patients with sepsis were further stratified for age, under or over 65 years, and for abdominal or pulmonary localisation of the septic focus. Metabolic stress and trauma patients were also stratified for age. Each subgroup was randomized to receive one of two nutritional support regimens. Both TPN solutions were isonitrogenous and isocaloric. The enriched solution contained $50.2 \% \mathrm{BCAA}$, and the conventional or standard solution contained $15.6 \%$ BCAA. Morbidity was assessed by separate evaluation of the functioning of four organ systems: respiratory function, cardiac function, renal function and liver function. The catabolic index as proposed by Bistrian was used to assess metabolic stress. Sepsis was scored using the Elebute and Stoner sepsis gradation. This chapter is concluded with the description of the design of the study, and of the statistical considerations.

The effects of both nutritional regimens on nitrogen balance but especially on morbidity and mortality are reported in chapter 3. Morbidity was assessed by the scoring of respiratory, cardiac, renal and liver function. Mortality was recorded as early sepsis related, late sepsis related and not-sepsis related. The administration of the BCAA enriched TPN solution to patients with moderate metabolic stress resulted in a less negative nitrogen balance if compared to the group receiving the standard solution. However, no differences with regard to morbidity and mortality were observed in the total study group, or the subgroup suffering from moderate metabolic stress. We concluded that BCAA enrichment of TPN solutions may possibly induce a more efficient nitrogen economy, but also that this manipulation of a supportive therapy has no favourable effect on outcome in patients with sepsis or metabolic stress.

In chapter 4 the effects of infusion of the above mentioned amino acid solutions on plasma proteins and plasma cells, specifically lymphocytes, leucocytes and thrombocytes are reported. While nitrogen balances were not different in both study groups, an increase of total protein was observed in the group receiving the standard amino acid solution leading to a significant difference with the group receiving the BCAA enriched solution on day 7 of the study. Pre-albumin levels increased significantly in both study groups. The number of rod shaped neutrophils was significantly lower and the number of lymphocytes and thrombocytes was significantly higher in the group receiving the standard solution compared with the group receiving the BCAA enriched solution. These results indicate that BCAA enrichment of TPN solutions does not result in a more efficient nitrogen metabolism. 
Sepsis and trauma are reported to induce changes in plasma amino acid concentrations. However, there is no concensus as to whether these changes in concentrations and ratios are specific for sepsis and/or trauma. The association of metabolic stress and sepsis with plasma amino acid patterns was investigated in 65 patients who did not receive prior nutritional support (chapter 5 ). Metabolic stress was assessed using the catabolic index while the severity of sepsis was evaluated employing the Elebute and Stoner sepsis score. Three levels of stress and sepsis severity were discerned. In addition to sepsis and stress the influence of renal and hepatic failure was analyzed. Plasma concentrations of virtually all amino acids were decreased with $10-30 \%$, while cystine and phenylalanine were significantly increased. These changes became more pronounced with increasing sepsis severity. Organ failure was not associated with significantly altered amino acid profiles. No differences were found between sepsis, and stress without signs of sepsis.

Effects of the use of BCAA enriched amino acid solutions on plasma amino acid patterns is described in chapter 6 . The use of BCAA enriched TPN solutions has been advocated on the assumption that these solutions normalize sepsis induced plasma amino acid profile distortions. The administration of a standard amino acid solution (15.6\% BCAA) or a BCAA enriched solution $(50.2 \% \mathrm{BCAA})$ in 101 patients with as carefully as possible assessed sepsis and stress resulted in an imbalance of the plasma concentrations of the essential amino acids. The amino acids valine, leucine and isoleucine increased significantly, but the other essential amino acids decreased significantly in the group receiving the BCAA solution. In the group of patients receiving the standard amino acid solution a gradual, but not significant increase of the BCAA, and a significant rise of the other essential amino acids was observed.

The Elebute and Stoner sepsis score has predictive value concerning mortality in patients with sepsis. In chapter 7 is investigated whether the Elebute and Stoner scoring system has an equal predictive value with regard to mortality in traumatized patients. This study demonstrates that the ES-score on day 0 indeed predicts outcome adequately. The addition of morbidity parameters, assessed by the scoring of four organ systems, further improved the predictive value of the ES-sepsis score. 
$\therefore$

$\therefore \quad \therefore \quad=$

$\therefore \quad$ 


\section{Samenvatting}

In hoofdstuk 1 wordt de achtergrond van het onderwerp van dit proefschrift beschreven. In sepsis en trauma wordt het metabolisme gekenmerkt door een toegenomen eiwitafbraak en eiwitsynthese, leidend tot een netto eiwitverlies en een toegenomen gluconeogenese. Ook is er een toegenomen lipolyse om in de toegenomen energie behoefte te kunnen voorzien. De vertakte keten aminozuren (VKAZ) valine, leucine en isoleucine zijn essentiele aminozuren, die als enige aminozuren direct en volledig in de spier kunnen worden geoxideerd en die daarmee een potentiele energiebron zijn. In in vitro experimenten zijn aan de VKAZ eiwitsparende eigenschappen toegedacht. Stimulatie van de eiwitsynthese wordt toegeschreven aan valine, leucine en isoleucine, terwijl leucine, en vooral $\alpha$-keto-isocapronzuur, een vermindering van de eiwitafbraak geven. Dier-experimenteel onderzoek leert dat toediening van aminozuur oplossingen in sepsis een stikstofsparend effect heeft, dat wordt versterkt als toenemende doses VKAZ worden gegeven. Een aantal studies vermeldt een toegenomen eiwitsynthese in lever en spier, terwijl een aantal andere studies vermindering van de 3-methylhistidine excretie of kleine arterio-veneuze aminozuur concentratie verschillen vermelden, wijzend op een verminderde proteolyse. Het gebruik van aminozuur oplossingen verrijkt met $\mathrm{VKAZ}$ in de kliniek leidt vaak tot een significante verbetering van de stikstof balans als wordt vergeleken met standaard aminozuur oplossingen. Deze bevindingen worden niet door alle studies bevestigd. Ook de immuun-functie, bepaald d.m.v. absoluut lymfocyten aantal en verandering in "delayed cutaneous hypersensitivity", verbetert als gevolg van het gebruik van VKAZ-verrijkte voeding, evenals de toename van de "short turn-over" eiwitten. Morbiditeit en mortaliteit worden vaak niet vermeld of er wordt slechts summier melding van gemaakt.

In hoofdstuk 2 worden de doelstellingen, het eigen onderzoek, de patienten en de methoden besproken. Voornaamste doelstelling is na te gaan of TPN met een aminozuur-oplossing, verrijkt met VKAZ, leidt tot een verbetering van de stikstof-balans, vergeleken met TPN met een standaard oplossing. Andere doelstellingen zijn: onderzoek of morbiditeit en mortaliteit verbeteren alsgevolg van toediening van VKAZ-verrijkte voeding, analyse van de plasma aminozuur patronen, analyse van de effecten van infusie van de twee aminozuur oplosingen op 
de plasma aminozuur patronen, evaluatie van scorings-systemen voor sepsis en morbiditeit. De patienten groep werd gestratificeerd naar sepsis en metabole stress of trauma. De sepsis groep werd verder gestratificeerd naar leeftijd van 16 tot 65 jaar en 66 jaar en ouder, en naar localisatie van de sepsis abdominaal of pulmonaal. De trauma groep werd eveneens gestratificeerd naar leeftijd. Iedere subgroep werd gerandomiseerd ten aanzien van het voedingsregiem. Beide TPN oplossingen zijn isonitrogeen en isocalorisch. De VKAZ-verrijkte oplossing bevat $50.2 \%$ VKAZ, terwijl de conventionele of standaard oplossing $15.6 \%$ VKAZ bevat. De laboratorium bepalingen worden beschreven, evenals de wijze waarop de morbiditeit parameters aan de hand van orgaan functiestoomissen worden bepaald. Ter bepaling van de metabole stress wordt de catabole index volgens Bistrian gebruikt, terwijl sepsis wordt gescored met behulp van de sepsis gradatie volgens Elebute en Stoner. Het studie ontwerp en statistische overwegingen besluiten dit hoofdstuk.

In hoofdstuk 3 worden de effecten beschreven van toediening van een VKAZ verrijkte TPN-oplossing vergeleken met een standaard aminozuur oplossing bij 101 patienten met sepsis en metabole stress op de stikstof balans. Vooral echter wordt bestudeerd wat de effecten zijn op morbiditeit en mortaliteit. Morbiditeit wordt bepaald aan de hand van de functie van de meest vitale orgaansystemen. Mortaliteit wordt onderscheiden in vroeg-en laat sepsis gerelateerd en niet-sepsis gerelateerd. Patienten met matige metabole stress hebben een minder negatieve stikstof balans, maar zowel voor deze groep als voor de totale groep geldt, dat er geen belangrijke verschillen worden gevonden in morbiditeit en mortaliteit. De conclusie is dat de VKAZ-verrijkte aminozuur oplossing geen duidelijk gunstig effect heeft bij patienten met sepsis en metabole stress, vergeleken met een conventionele aminozuur oplossing.

In hoofdstuk 4 worden de effecten beschreven van de twee eerder genoemde TPN-oplossingen, op plasma-eiwitten en cellen, met name lymphocyten, leucocyten en thrombocyten, hetgeen kan wijzen op een verbeterde immuun-functie. De stikst of balansen blijken voor beide voedingsregiems niet verschillend. In de standaard groep blijkt een significante toename van het totaal eiwit hetgeen leidt tot een significant verschil met de VKAZ verrijkte groep op dag 7 van de studie. Prae-albumine stijgt significant in beide groepen. Het aantal staafvormige leucocyten blijkt in de standaard groep significant lager en het aantal lymphocyten en thrombocyten significant hoger vergeleken met de VKAZ-verrijkte groep. Deze resultaten duiden erop dat VKAZ-verrijking van TPN-oplossingen niet leidt tot een efficienter stikstof-metabolisme. 
Sepsis en trauma leiden tot veranderingen in plasma-aminozuur concentraties in vergelijking met een controle groep van 30 gezonde personen. Er bestaat echter geen consensus over of deze veranderingen in concentraties en ratio's van aminozuren specifiek zijn voor sepsis en/of trauma. De plasma aminozuur patronen van 65 patienten met sepsis en metabole stress, die tevoren geen TPN hadden gekregen, werden beschouwd. Metabole stress werd bepaald met behulp van de catabole index (Bistrian) en sepsis met behulp van de Elebute en Stoner sepsis gradatie. Drie graden van ernst van sepsis en metabole stress werden onderscheiden. Ook de invloed van nier- en/of leverfunctiestoornissen werd bestudeerd (hoofdstuk 5). Bijna alle aminozuren in plasma blijken $10-30 \%$ verlaagd, terwijl cystine en phenylalanine significant verhoogd zijn. Deze bevindingen zijn meer uitgesproken naarmate de sepsis ernstiger is. Functiestoornissen van nier en/of lever hebben geen significante invloed, terwijl evenmin verschillen in aminozuur patroon tussen patienten met sepsis en metabole stress worden gevonden.

Het gebruik van aminozuur oplossingen verrijkt met VKAZ, is gebaseerd op de opvatting dat deze verrijkte oplossingen in staat zijn veranderde plasma aminozuur patronen te normaliseren. De effecten op de plasma aminozuur concentraties als gevolg van toediening van een standaard aminozuur oplossing (15.6\% VKAZ) en een VKAZ-verrijkte oplossing (50.2\% VKAZ) werden bestudeerd bij 101 patienten die parenteraal werden gevoed en waarbij sepsis en stress zo zorgvuldig mogelijk werden bepaald (hoofdstuk 6). Infusie van de VKAZ-verrijkte oplossing leidt tot een verstoorde balans van de essentiele aminozuren in plasma. De aminozuren valine, leucine en isoleucine stijgen significant, terwijl de overige essentiele aminozuren significant dalen. In de patientengroepen die de standaard aminozuur oplossing krijgen, stijgen de VKAZ geleidelijk, maar niet significant, terwijl de overige essentiele aminozuren significant stijgen.

De Elebute en Stoner (ES) score heeft niet alleen voorspellende waarde t.a.v. de mortaliteit bij patienten met sepsis, maar ook bij patienten met matabole stress/trauma, indien de ES-score van dag 0 wordt beschouwd. Tevens blijkt dat de morbiditeit als deze wordt bepaald door vier belangrijke orgaansystemen te scoren, een aanvulling betekent op de voorspellende waarde van de ES score t.a.v. mortaliteit (hoofdstuk 7). 


\section{Acknowledgements}

The clinical study that finally resulted in this thesis has only been possible because of a joint effort of many people during a number of years. I want to emphasize that without them a trial of this magnitude could not have been done.

I thank Prof.Peter Soeters who was the initiator of the BCAA study, for giving me the opportunity to work on this subject and for guiding me into this material. I admire your ability to listen to people and to analyze problems.

I especially thank Dr. Maarten von Meyenfeldt. You were the driving force that accompanied me and kept me on the right path whenever necessary. I am very grateful for your continuous enthousiasm and your active support during the whole study.

I thank Prof. Co Greep who introduced me in the department of surgery in Maastricht. I very much appreciate your wide interest and your controlling capacities that reached even as far as Woerden.

I am indepted to Dr. Dirk Gouma and Dr. Cees van der Linden who both critically reviewed parts of the manuscript.

I thank Prof. Saris, Prof. de Lange, Dr. Sauerwein, Prof. Sitges-Serra, Prof. Stockbrïgger and Prof. Wesdorp for their critical review of the final manuscript of this thesis.

I am very grateful to Margriet Roufflart and to Dr. Charles van Berlo. They spent much time and energy in calculating nutritional data. I also thank Koert de Jong for his part in the study and Getlin Visser who calculated the basal energy expenditure data. I also thank Dr. A. Volovics for all his help with the statistical analysis.

I thank Hans van Eijk for his excellent work on plasma amino acid determinations and Eugene Hardy for providing the amino acid solutions used in the study.

Marcia van Puijenbroek, Iny van Rees and especially Wilma Domen have done all the secretarial work for this thesis for which $\mathbb{I}$ am very grateful.

It is with pleasure that I remember the department of surgery of the Academisch Ziekenhuis Maastricht, headed by Prof. Co Greep and Prof. Gouke Kootstra. The time I spent in their midst was short but very intense!

I am obliged to my present colleagues in the surgical department for their good fellowship during the last years. 
I will al ways remember my father. He wanted all his children to study and made it possible. He would have been so proud.

Last but not least there is Aky. Without her optimism and perseverance this thesis would never have come to an end. Nobody is more able to motivate and to support than she is. 


\section{Curriculum vitae}

Hans Vente was born on February 10, 1950 in Zwolle, The Netherlands. He attended high school in Utrecht (gymnasium- $\beta$ ). In 1968 he went to medical school in Utrecht, State University, and graduated in 1975 . From 1975 to 1976 he worked as a resident in the Department of Surgery of the Zeister Hospital, and from 1976 to 1977 in the surgical department of the Johannes Hospital, Duisburg, Germany (Head: Prof. Dr. B. Kuss). In January 1978 he started his formal surgical training in the Groot Zieken Gasthuis, s'Hertogenbosch under the direction of Dr. J.H. Meiss. He was certified as a surgeon in 1984. He served as a junior staff surgeon in the Department of Surgery of the University Hospital Maastricht (Head: Prof. Dr. J.M. Greep) in 1985 and 1986. Since 1987 he is a member of the surgical staff of the Hofpoort Hospital, Woerden. 